\title{
La sexta ola o era del Estado constitucional democrático, social y ambiental -ECDSA- en Iberoamérica: reconstitucionalización y pluralismo tridimensional
}

The sixth wave (or era of the democratic, social and environmental constitutional state -ECDSA-)

in Latin America: reconstitutionalization and three-dimensional pluralism

A sexta onda ou época do Estado constitucional democrático, social e ambiental - ECDSA - na Ibero-América: reconstitucionalização $e$ pluralismo tridimensional

La sixième vague ou ère de l'État constitutionnel démocratique, social et environnemental -ECDSAen Ibero-Amérique: reconstitutionnalisation et pluralisme tridimensionnel

伊比利亚美洲民主, 社会和环境宪法制国家的第六次浪潮或 时代 - ECDSA -重构和三维多元化

\author{
Bernd Marquardt ${ }^{1}$ \\ Universidad Nacional de Colombia - Colombia
}

\footnotetext{
Profesor titular en la Facultad de Derecho, Ciencias Políticas y Sociales de la Universidad Nacional de Colombia, sede Bogotá. Es fundador y director del grupo de investigación CC Constitucionalismo Comparado (A1) e investigador sénior en Colciencias. Realizó el Doctorado en Derecho con la calificación summa cum laude (1999), sus estudios postdoctorales (2000) y su segundo doctorado superior -la Habilitation centroeuropea (2003)- en la Universidad de Sankt Gallen, en Suiza. Dispone de otro postdoctorado en Derecho de la Facultad de Derecho de la Universidad Nacional de Colombia (2018). De igual forma, es magíster, incluyendo el pregrado en Derecho de la Universidad Georgia Augusta de Gotinga en la República Federal de Alemania (Erstes Juristisches Staatsexamen, 1995). Tiene actualmente 208 publicaciones, con 26 libros completos, incluyendo el primer tomo de la Historia del derecho de Hispanoamérica en perspectiva transnacional y socio-cultural (2019), los dos tomos de la Teoría integral del Estado (2018), Ius contra bellum (2017), Historia constitucional comparada de Iberoamérica
} 
Revista Derechos en Acción ISSN 2525-1678/ e-ISSN 2525-1686

Año 5/Nº 14 VERANO 2019/20 (21 diciembre a 20 marzo), 79-196

DOI: https://doi.org/10.24215/25251678e356

ORCID: https://orcid.org/0000-0001-6172-6110

Recibido: $15 / 02 / 2020$

Aprobado: 05/03/2020

Resumen: El presente artículo analiza las transformaciones constitucionales de lberoamérica en los últimos tres decenios y medio con un enfoque en la reconstitucionalización pluralista después del interludio de las autocracias republicanas. Iniciará con una introducción al constitucionalismo comparado según el modelo de las seis olas, para continuar con la conceptuación de la época, preguntando por las ventajas y desventajas de los constructos del neoconstitucionalismo y del ECDSA. En tercer lugar, examinará las dinámicas de transformación y las nuevas normas supremas. El cuarto apartado sondeará las tendencias en el equilibrio horizontal y vertical de poderes. Quinto, se revisará el perfil pluralista y el enfoque en el triángulo de valores liberales, sociales y ambientales. El sexto subcapítulo echará un vistazo a la integración continental y la protección supranacional de valores constitucionales. Para terminar, se formulan algunas observaciones conclusivas sobre constituciones extensas, idealistas, transformadoras y parcialmente normativas.

Palabras claves: Estado constitucional democrático, social y ambiental; constitucionalismo comparado; constituciones transformadoras y aspiracionales; superación del anti-constitucionalismo

Abstract: This article analyses the constitutional transformations in Ibero-America over the last three decades with a focus on pluralist reconstituteionalization after the interlude of republican autocracies. The article will begin with an introduction to comparative constitutionalism according to the six-wave model, to continue with the conceptualization of the era, asking about the advantages and disadvantages of the constructs of neoconstitutionalism and ECDSA. Thirdly, it will examine

(2016), Derechos humanos y fundamentales, Una historia del Derecho (2015) y La historia del Estado moderno en Asia y África del Norte (2014). Correo electrónico: b.marquardt@gmx.ch 
the dynamics of transformation and the new supreme norms. The fourth section will probe the tendencies in the horizontal and vertical balance of power. Fifth, it will review the pluralist profile and focus on the triangle of liberal, social and environmental values. The sixth sub-chapter will look at continental integration and supranational protection of constitutional values. In conclusion, some concluding remarks are made on extensive, idealistic, transformative and partially normative constitutions.

Keywords: democratic, social and environmental constitutional state; comparative constitutionalism; transformative and aspirational constitutions; overcoming anti-constitutionalism.

Resumo: 0 presente artigo analisa as transformações constitucionais da lbero-América nas últimas três décadas e meia, com foco na reconstitucionalização pluralista após o interlúdio das autocracias republicanas. Começará com uma introdução ao constitucionalismo comparativo de acordo com o modelo de seis ondas, para continuar com a conceituação da época, perguntando pelas vantagens e desvantagens dos constructos do neoconstitucionalismo e da ECDSA. Terceiro, examinará a dinâmica da transformação e as novas normas supremas. A quarta seção sondará as tendências no equilíbrio horizontal e vertical de poderes. Quinto, serão revistos o perfil pluralista e o foco no triângulo de valores liberais, sociais e ambientais. 0 sexto subcapítulo examinará a integração continental e a proteção supranacional dos valores constitucionais. Para concluir, são feitas algumas observações finais sobre constituições extensas, idealistas, transformadoras e parcialmente normativas.

Palavras-chave: Estado constitucional democrático, social e ambiental; constitucionalismo comparativo; constituições transformadoras e aspiracionais; superação do anticonstitucionalismo.

Résumé: Cet article analyse les transformations constitutionnelles iberoaméricaines au cours des trois dernières décennies et demie en mettant l'accent sur la reconstitutionnalisation pluraliste après l'intermède des autocraties républicaines. II commencera par une introduction au constitutionnalisme comparé selon le modèle à six vagues, pour poursuivre avec la conceptualisation de l'époque, en s'interrogeant sur les avantages et les inconvénients des constructions du néoconstitutionnalisme et de l'ECDSA. Troisièmement, il examinera les dynamiques de transformation et les nouvelles normes suprêmes. La quatrième 
section explorera les tendances dans l'équilibre horizontal et vertical des pouvoirs. Cinquièmement, il passera en revue le profil pluraliste avec l'accent mis sur le triangle des valeurs libérales, sociales et environnementales. Le sixième sous-chapitre examinera l'intégration continentale et la protection supranationale de valeurs constitutionnelles. Pour terminer, quelques observations conclusives sont faites sur les constitutions extensives, idéalistes, transformatrices et partiellement normatives.

Mots-clés: Etat constitutionnel démocratique, social et environnemental; constitutionnalisme comparé; constitutions transformatrices et ambitieuses; surmonter l'anti-constitutionnalisme.

摘要: 本文分析了伊比利亚-美洲在过去三年半中的宪政转型, 重点 是共和制专制政体介入之后的多元制宪。首先将根据六波模型介绍 比较立宪主义, 然后继续进行时间概念化, 并询问新宪法 -ECDSA构架的优缺点。第三，它将研究变革的动力和新的最高准则。第四部 分将探讨水平和垂直力量平衡的趋势。第五，将审查多元化的概况 以及对自由, 社会和环境价值三角形的关注。第六章将探讨大陆一 体化和宪法价值的超国家保护。总而言之, 对广泛的, 理想的, 变革 的和部分规范的宪法做出了一些结论性意见。

关键词:民主, 社会和环境宪政国家; 比较立宪主义; 变革性和理想 的体质;克服反宪法主义。

\section{Constitucionalismo comparado: el modelo de las seis olas}

El presente estudio se dedica en perspectiva comparada a las transformaciones del derecho constitucional iberoamericano a partir de la década de 1980. Para ello, se fundamenta en la escuela socio-cultural y transnacional del derecho constitucional y su bistoria que el autor ha desarrollado en varias de sus obras $^{2}$. Principalmente, la misma se caracteriza por los siguientes siete postulados teóricos-metodológicos:

2 De modo más reciente y completo en: Marquardt, Historia del derecho de Hispanoamérica, pp. $31-86$ 
En primer lugar, no es normacéntrica, sino que analiza el texto en su contexto, dedicándose a las precondiciones y consecuencias de la normatividad; segundo, es interdisciplinaria, sin subestimar las miradas complementarias de la ciencia política, sociológica, ciencia ambiental etc.; tercero, se adscribe a la perspectiva mundial, enfocada en precisar el lugar de Hispanoamérica en el escenario planetario, bajo el postulado de aplicar los mismos estándares de crítica y respeto a toda zona del planeta, evitando prejuicios geopolíticos burdos como los de tipo primer-tercermundismo o sus derivados (norte-sur, etc.); cuarto, parte de la relevancia central de la gran transformación ocurrida alrededor de 1800 que llevó al nacimiento de un nuevo tipo de Estado, el constitucional-republicano, que rompió con los cinco milenios de la predominancia mundial de la monarquía dinástica; quinto, observa la difusión del mismo en el espacio global en olas ${ }^{3}$, contra-olas, contra-contra-olas bajo la transformación permanente que busca materializar, en últimas, el valor central de la dignidad humana de todos los ciudadanos; sexto, se enfoca en el significado transformador del derecho constitucional, no solo entendiéndolo como la supuesta normatividad bien establecida, sino como algo aspiracional en búsqueda permanente de crear un entorno más justo; séptimo, adopta propuestas metodológicas de la historia del tiempo reciente con sus logros de hacer expresable también lo gris, negro y traumático, en contra de la tendencia de diversos autores jurídicos de blanquear su objeto de estudio.

Panorámicamente, puede pensarse la historia comparada del Estado constitucional en Hispanoamérica como compuesta por seis fases nucleares con características, orientaciones y perfiles cada vez predominantes. No pueden ser malentendidas como mecánicamente repetidas en todos los países exactamente en el mismo momento y en la misma profundidad, sino que se impusieron en ventanas temporales de uno a dos decenios, bajo

3 Solo en términos lingüísticos, este modelo de las olas se inspira en Huntington, pero se distingue en su composición, contenidos y factores relevantes. 
particularidades significativas y también hubo siempre excepciones de países que se comportaron de modo contracíclico. Estas seis olas pueden caracterizarse de la siguiente manera:

1. La transformación originaria al Estado republicano de la Ilustración política (1810-1847).

2. El alto liberalismo hispanoamericano (aprox. 1848 década de 1880).

3. El alto nacionalismo (aprox. 1880-1916).

4. La fase del complemento del republicanismo liberal por el constitucionalismo de la democracia social (1917-1949).

5. El anti-constitucionalismo dictatorial ante la Guerra Fría mundial y la crisis de transformación a la sociedad industrial (aprox. 1950 - década de 1980).

6. La era del Estado constitucional democrático, social y ambiental -ECDSA- bajo signos de la reconstitucionalización y transformación al pluralismo tridimensional (desde los años 80 del siglo XX hasta el presente) $)^{4}$.

El presente artículo desarrolla a profundidad la última.

\section{La cuestión conceptual: ¿neoconstitucionalismo o era del ECDSA?}

Con frecuencia, la bibliografía caracteriza la sexta ola con la terminología del neoconstitucionalismo ${ }^{5}$, pero en el presente texto se considera más preciso partir de la era del Estado constitucional democrático, social y ambiental -ECDSA ${ }^{6}$ - en el sen-

4 En detalle: Marquardt, Historia constitucional comparada de Iberoamérica, pp. 64 y ss.

5 Comp. Ios debates en: Bernal P., El neoconstitucionalismo, pp. 77 y ss; Carbonell, Teoria del neoconstitucionalismo; Íd., Neoconstitucionalismo(s); Echeverri \& Duque, Política y constitucionalismo, pp. 80 y ss; Gargarella, La sala de máquinas, p. 10; Llinás, Constitución y ética constitucional, pp. 9 y ss; Suárez, El nuevo constitucionalismo latinoamericano, pp. 265-336; Uprimny, Las transformaciones constitucionales recientes, pp. 122 y ss.

6 Teoría del ECDSA: Marquardt, Teoría integral del Estado II, pp. 500 y ss. Retomado por: Llinás, Constitución y ética constitucional, pp. 58 y ss (que entiende Estado constitucional de Derecho como sinónimo). 
tido dual de la reconstrucción del republicanismo constitucional en una zona con extendidas tradiciones constitucionales desde 1810 bajo profundizaciones que crearon algo materialmente novedoso. El problema de la teoría del neoconstitucionalismo es que invita a un malentendido doble en la dialéctica entre reconstitucionalización e innovación.

Por una parte, dirige a pensar en un acto fundador que hubiera llevado a un continente oscuro a su primera luz, igualándose supuestamente a antiguos logros europeos, de modo que se subestima múltiples elementos de larga trayectoria que mostraban mayores tradiciones locales que en Europa: no fueron nuevos ni el constitucionalismo liberal hispanoamericano como tal con su antehistoria a partir de 1810, ni el constitucionalismo social desde 1917; tampoco se inventó ahora la supremacía de la constitución y menos los derechos fundamentales con su tradición bicentenaria. Tampoco debe desconocerse que la justicia constitucional hispanoamericana permite identificar una antehistoria desde la carta cundinamarquesa de 1811.

Por otra parte, la teoría del neoconstitucionalismo tiende a desviar de la profundidad transformadora de su propia época en comparación con lo pre-dictatorial. En realidad, ocurrió mucho más que un simple renacimiento de las ideas del siglo XIX. Entre los elementos novedosos en términos cualitativos, destacan siete ${ }^{7}$ : primero, el pluralismo tridimensional de valores que completó el nivel liberal del siglo XIX y el social del siglo XX con el tercer componente, el ambiental, estableciendo así un triángulo de valores constitucionales que puede entenderse como el carácter nuclear del ECDSA; en ello, se fortaleció también el componente social proveniente de la cuarta ola (1917-1949) hasta un concepto integral; segundo, estas constituciones fueron muy generosas en sus derechos garantizados, alrededor del punto de gravitación de la dignidad humana

7 Véase los autores de ambas notas anteriores y Jaramillo, Constitución, democracia y derechos, pp. 42 y ss, 94 y ss. 
de origen weimariano ${ }^{8}$, superando en este idealismo textual a toda otra zona del mundo; tercero, no solo se entregó la protección y defensa de dichos derechos a los jueces, sino que en varios países la justicia constitucional se empoderó efectivamente al papel de un verdadero actor significativo y crítico en el esquema de la separación de poderes, superando la actitud sumisa del pasado; ahora, múltiples transformaciones precisas tenían su punto de partida en la rama judicial en vez del poder legislativo; cuarto, las constituciones se abrieron benevolentemente hacia el ius commune latinoamericano en derechos humanos y la respectiva jurisdicción hemisférica -lo que se incluyó típicamente al bloque de constitucionalidad-9; quinto, se establecieron normas claras contra el estadositismo abusivo de la fase anterior; sexto, se reanimaron los Congresos en su función clave como poderes legislativos, limitando significativamente la anterior proliferación del decretismo ejecutivo; séptimo, ahora se valorizó positivamente la diversidad étnica en contra de la anterior tendencia homogeneizadora del Estado nación hispano-cultural. Con respecto a los derechos fundamentales, en vez de contentarse con cualquier concreción legislativa de los mismos, se entró definitivamente en la era de la constitucionalidad rígida cuyo núcleo puede ser descrito por el término garantismo, difundido por los seguidores del pensador italiano Ferrajoli ${ }^{10}$.

Además, se recomienda repensar críticamente la tendencia de la teoría del neoconstitucionalismo a simplificar las reformas

8 Comp. el art. 1 de la CP de Brasil de 1988, el art. 1 de la CP de Colombia de 1991, el preámbulo y el art. 1 de la CP de Paraguay de 1992, el art. 1 de la CP del Perú de 1993, los arts. 3, 46, 47, 55, 80 y 81 de la CP de Venezuela de 1999, el art. 1 de la reforma chilena de 2005, el art. 84 de la CP del Ecuador de 2008, y el art. 22 de la de la CP de Bolivia de 2009.

9 P. ej., art. 93 de la CP de Colombia de 1991; art. 75 n 22 de la CP de Argentina de 1994; art. $13 \mathrm{n}^{0} 4$ de la CP de Bolivia de 2009. Cfr. Bogdandy, Ius Constitutionale Commune Latinoamericanum, p. 8; Ferreyra, Fundamentos constitucionales, pp. 274 y ss; Góngora M., La difusión del bloque de constitucionalidad, pp. 145-180; Morales A., El Estado abierto, p. 95; Uprimny Y., Bloque de constitucionalidad.

10 Véase Ferrajoli, Garantismo. Vid. Morales V., Derechos fundamentales y democracia, pp. 483-512. 
iberoamericanas como un presumido trasplante jurídico de los conceptos constitucionales italiano de 1947, alemán de 1949 y español de 1978. Es indudable que los padres de la generación constitucional de alrededor de 1990 estudiaron, entre otros materiales, dichas constituciones exitosas de Europa y algunos de sus teóricos traducidos como el alemán Alexy ${ }^{11}$, adoptando varias figuras como la dignidad humana y el Estado social de derecho, pero se considera inadecuada la connotación eurocéntrica y sumisa que subestima tanto los debates propios como la capacidad de reformarse y desarrollarse dentro del marco preexistente de la familia del ius commune constitucional de Latinoamérica. Tampoco deben minimizarse otras fuentes, pues es evidente que el constitucionalismo iberoamericano de la sexta ola es mucho más cercano al constructo iushumano de las Naciones Unidas de 1966 que al modelo alemán de 1949.

\section{Dinámicas de transformación y nuevas normas supremas}

Entre 1983 y 1991, América Latina logró la salida de la fase del anti-constitucionalismo que había perturbado, desde la segunda mitad de los años 40, una de las zonas fundadoras del Estado constitucional en el mundo. Paso por paso, desaparecieron tanto las longevas dictaduras como las demo-autocracias híbridas. Se derrumbó la cultura política de los golpes de Estado y del estadositismo.

\section{a. Factores favorables que promovieron la sexta ola}

En primer lugar, vale la pena repensar los factores favorables de la sexta ola. Se indicarán siete contextos principales, parcialmente exógenos y endógenos.

De modo prioritario, hay que echar un vistazo a la transformación del sistema internacional, teniendo en cuenta que la construcción de redes de Estados satelitales leales en la

11 Alexy, Teoría de los derechos fundamentales. 
bipolaridad mundial de la Guerra Fría había sido el gran motor del anti-constitucionalismo latinoamericano, de modo que la superación de la Guerra Fría alrededor de 1989, llevó al abandono de la respectiva política imperial y hegemónica de los EE.UU. Ahora, Washington percibió como más problemática la mala reputación internacional del patrocinio de gobiernos marionetas que lucharon ferozmente contra 'enemigos públicos' estigmatizados como sospechosos de ideales pro-soviéticos. Especialmente, el protegido Pinochet se transformó, en los ojos de la ciencia y prensa internacional, en el símbolo mundial del anti-constitucionalismo y de la contra-modernidad indeseada. También la dura sentencia del Tribunal Internacional de Justicia en La Haya de 1986, que declaró visiblemente para todo el mundo que la intervención encubierta de los EE.UU. en Nicaragua había violado el derecho internacional público ${ }^{12}-$, motivó que pareciera sensato renunciar a la política de la mano dura $^{13}$. Paralelamente, los EE.UU. aprendieron que era mucho más eficiente promover políticas de lealtad económica y aprovisionamiento prioritario con recursos naturales a través de las instituciones internacionales financieras con sede en su capital y la imposición del llamado Consenso de Washington en negociaciones sobre la condonación de deudas públicas y créditos condicionados. Segundo, en vez de la seguridad hemisférica de tipo estadounidense, ascendió la ética iushumana de las Naciones Unidas al rango de la verdadera estrella de orientación ética de la época. Tercero, el mundo policéntrico del siglo XXI abrió para América Latina nuevos espacios de independencia material, por ejemplo en forma de relaciones comerciales con China en vez de la orientación clásica hacia el norte. Paralelamente, Brasil mismo ascendió al rango de candidato de uno de los centros del mundo policéntrico del siglo XXI.

\footnotetext{
12 ClJ, Military and Paramilitary Activities in and against Nicaragua (Nicaragua v. United States of America). Cfr. Ganser, Illegale Kriege, pp. 146 y ss.

13 Comp. Bos, Verf.gebung u. Systemwechsel, pp. 116 y ss, 157 y ss, 230 y ss; Vergottini, Las transiciones constitucionales, pp. 188 y ss.
} 
Por otra parte, en términos endógenos, se materializó la fuerza de resurrección que era inmanente a la tradición propia de dos siglos del constitucionalismo moderno, de la democracia electoral, de la separación de poderes y de los derechos fundamentales. En ello, también la ética profesional de los profesores universitarios, juristas y otros académicos socializados en los valores del constitucionalismo democrático, presionó profundamente la corrección de desviaciones incompatibles. En quinto lugar, los autócratas sin concepto propio de legitimidad y con base en la mera lógica de la excepción salvadora, entraron después de algunos años en el poder en una situación paradójica, pues la excepción permanente pareció contradictoria en si misma. Incluso muchos presidentes de facto se autopercibieron más como actores pasajeros para superar la supuesta crisis del momento en vez de alternativas permanentes. Tampoco lograron mostrar mayores resultados políticos y económicos en comparación con las democracias supervivientes como Costa Rica. Sexto, también las guerrillas insurgentes perdieron, con el fin de la Guerra Fría, su modelo ideal del comunismo soviético, reorientándose hacia políticas más o menos socialdemócratas dentro de la institucionalidad del constitucionalismo socioliberal. Séptimo, todos los actores aceptaron, al fin, el carácter irreversible de la gran transformación a la sociedad industrial, con un perfil socio-cultural diferente de la sociedad burguesa y propietarista del siglo XIX. Tampoco debe subestimarse la influencia del atractivo de las democracias consumistas de la Europa occidental que lograron vivir tranquilamente sin estadositismo teatral ni militarización de la cotidianidad. Complementariamente, los nuevos medios de comunicación, en particular la televisión, transmitieron sutilmente a todo el pueblo una experiencia democrática que pareció más atrayente que el aplauso del súbdito al caudillo en la calle.

\section{b. La caída de las dictaduras}

La primera transición significativa ocurrió en Argentina en 1983, terminando con casi tres decenios de predominancia 
dictatorial (1955-1958, 1962-1963, 1966-1973, 1976-1983). En el país del río de la Plata, la última y sangrienta junta militar de la Reorganización Nacional se vio seriamente deslegitimada, luego de su estrepitosa derrota militar frente a Gran Bretaña en la Guerra de las Malvinas (1982). No sucedió ninguna sublevación popular, pero la actuación de la sociedad civil jugó un papel importante en el ciclo de deslegitimación, especialmente a través de las manifestaciones semanales de las Madres de Plaza de Mayo que tematizaron insistentemente los asesinatos de sus hijos, minando de esta manera la imagen y autoestima de los gobernantes. En la etapa de transición, los militares se otorgaron una ley de auto-amnistía para evadir cualquier responsabilidad; sin embargo, aquella fue derogada inmediatamente después de la restitución del Congreso constitucional en 1983. Este hecho abrió las puertas al Juicio a las Juntas de 1985, donde se sentenció a reclusión perpetua a varios terroristas uniformados, entre ellos, el ex Presidente Videla (1976-1981) ${ }^{14}$.

En el año 1985, en la República oriental del Uruguay se dio fin -de manera negociada- a la dictadura de seguridad nacional que había existido desde 1973. A pesar de que la misma había perdido su plebiscito constitucional de 1980, continuó por cinco años más en el gobierno, aunque cada vez con menor respaldo popular. En un ambiente de críticas y protestas crecientes, se negoció el Pacto del Club Naval de 1984, con el cual el gobierno militar aprobó el regreso al gobierno constitucional en 1985. En 1986, se sancionó la polémica Ley de caducidad de la pretensión punitiva del Estado que concedió amnistía a favor de todos los "delitos cometidos hasta [...] 1985 por funcionarios militares y policiales"15.

14 Art. 1 de la Ley argentina 22.924 de 1983; art. 1 de la Ley 23.040 1983; CNCrim, Causa 13/84. Cfr. Cantón, Leyes de amnistía, pp. 280 y ss; Carreras \& Potthast, Eine kleine Geschichte Argentiniens, pp. 228 y s; Echeverri U. \& Duque A., Política y constitucionalismo, p. 218; Laughland, A History of Political Trials, pp. 181 y ss; Merkel, Systemtransformation, pp. 215, 223, 233 y ss.

15 Art. 1 de la Ley 15.848 de 1986. Comp. Arteaga, Breve historia del Uruguay, pp. 283 y ss; Cantón, Leyes de amnistía, pp. 277 y ss; Gros \& Esteva, Constituciones Uruguay, pp. 153 y ss. 
Una de las transiciones más tranquilas tuvo lugar en Brasil, sin presión bélica ni de plebiscitos perdidos. Esta dictadura militar multidirigente con sus cambios cíclicos entre oficiales de turno, posibilitó por sí misma el ascenso de presidentes moderados con ciertas ideas liberales, en particular Geisel (1974-1979) y Figueiredo (1979-1985), quienes promovieron progresiva y gradualmente una apertura hacia las elecciones de 1985, ganadas por el candidato de la oposición civil con posturas políticas no tan lejanas a las de los antiguos dirigentes. El proceso se concluyó con la constitución federal de 1988 y el plebiscito de 1993 sobre la forma de gobierno que legitimó ex post la caída de la monarquía de los Braganza en $1889^{16}$.

Como una de las transiciones más simbólicas, se considera la caída de la dictadura militar del general Pinochet en Chile (1973-1990). En 1988, aquel lanzó un nuevo plebiscito -de acuerdo con el procedimiento previsto en la constitución dictatorial de 1980-, convencido de que el resultado solo podía ser la confirmación de su permanencia en el poder por ocho años más, de manera similar a los anteriores plebiscitos del régimen. No obstante, la dictadura perdió contra una mayoría de opositores del 55 \%. El gobierno militar aceptó su derrota, aunque continuó por un año y medio en sus funciones, periodo en el cual los antiguos y futuros gobernantes negociarían un pacto político, que fue aprobado por el 91,25\% de los votantes en el plebiscito de reforma constitucional de 1989. De tal manera, se eliminó el núcleo autoritario de la carta de 1980 que había sido anclado en las disposiciones transitorias, y se curó superficialmente, a través de poder constituyente del pueblo soberano, el defecto de nacimiento de la carta de 1980. Sin embargo, no debe ignorarse que el ex dictador Pinochet se reservó un poder de fondo, pues se perpetuó durante ocho años más como Comandante en Jefe del Ejército de Chile y, de esta manera, como dirigente máximo de lo que el artículo 90

16 CP de Brasil de 1988. Cfr. Cunha, Do constitucionalismo brasileiro, pp. 270 y s; Silva, Constituciones Brasil, pp. 43 y ss. 
de la carta continuó entendiendo como el guardián de la constitución; además, fue miembro del poderoso Consejo de Seguridad Nacional y senador vitalicio (hasta 2002). La tropa todavía fue un enclave autónomo, pero no abusó de sus facultades. Una parte de la transición pactada fue la confirmación del Decreto ley de auto-amnistía de 1978 y la renuncia de los nuevos dirigentes a revocar el derecho administrativo 'neoliberal' decretado por la dictadura. En general, puede reconocerse un elemento paradójico en el hecho de que el sistema constitucional, que nació en 1989 contra el anti-constitucionalismo de los dos decenios anteriores, se basó expresamente en la ficción de la continuidad de la carta de la dictadura de $1980^{17}$.

Fue diferente el perfil de transición en Paraguay donde, en 1989, el golpe de Estado del general Rodríguez derrocó al longevo dictador Stroessner que había gobernado desde 1954. El militar Rodríguez prometió la democratización, aunque no debe subestimarse la subsiguiente elección del golpista y socio de partido del ex dictador a la presidencia de la república, pero solo por un periodo, hasta el año $1993^{18}$. La calidad limitada de la transición puede reconocerse en el hecho de que continuó en el poder el Partido Colorado de Stroessner hasta 2008 y, después de una breve interrupción, nuevamente a partir de 2013 hasta hoy.

El único caso de una transformación debida a una intervención militar desde afuera, sucedió en Panamá. En 1989, los EE.UU. derrocaron al dictador istmeño y presunto narcotraficante Noriega, terminando de tal manera con el régimen militar existente desde 1968; luego, se promulgó la constitución de 1994.

\footnotetext{
17 Ley 18.825 de reforma constitucional de 1989; Decreto ley 2.191 de 1978. Sobre esta transición: Barros, Constitutionalism and dictatorship, pp. 308 y ss; Bos, Verf.gebung u. Systemwechsel, p. 120; Cristi \& Ruiz, La república en Chile, pp. 130 y ss., 197 y ss.; Merkel, Systemtransformation, pp. 216, 224 y ss., 236 y ss.; Naranjo, Teoría constitucional, p. 675; Nogueira, Decreto ley de amnistía, pp. 107-130; Nolte, Zurück zur Demokratie, p. 40; Ramón, Historia de Chile, pp. 278 y ss.; Thibaut, Präsidentialismus, pp. 219 y ss.

18 Silvero S., Die Verfassung der Republik Paraguay, pp. 609 y s.
} 
Como ejemplo de una transición con base en un acuerdo de paz interno, puede destacarse El Salvador, donde una especie de asesinocracia electoral de la derecha pro-oligárquica se convirtió -con ocasión de los Acuerdos de Chapultepec de 1992- en un Estado constitucional, basado en la vitalización de la hasta entonces seudo-carta de 1983, reformada varias veces entre 1992 y $2000^{19}$.

Una de las transformaciones más lentas y ambiguas ocurrió en Guatemala. En este caso, el último dictador militar, Mejía Victores (1983-1986), inició -a pesar de los medios represivos de seguridad contrainsurgente durante sus primeros meses- una política de reconstrucción constitucional, convocando la elección de una Asamblea Nacional Constituyente en 1984, sosteniendo la carta de 1985 y reconociendo las elecciones que posibilitaron la presidencia de un abogado de la democracia cristiana en 1986. Sin embargo, la transición tardó más tiempo, ya que las fuerzas armadas aún actuaron como un Estado dentro del Estado. De ese modo, continuaron tanto las masacres y represiones de las tropas paraestatales, como las actividades de las guerrillas insurgentes. En el año 1993, el Presidente guatemalteco Serrano intentó un autogolpe; sin embargo, es llamativo que se defendió exitosamente la institucionalidad, pues la Corte de Constitucionalidad declaró inconstitucionales los decretos presidenciales y presionó la huida del mandatario al exterior. Un punto clave en la transición guatemalteca, puede reconocerse en el Acuerdo de paz firme y duradera de 1996. Sin embargo, el proyecto de constitucionalización de este Acuerdo que previó, entre otros, el mejoramiento de los derechos sociales y el reconocimiento del carácter multiétnico de la nación maya, fracasó en el polémico referéndum de 1999 -bajo una abstención de más del 90 \%-. De todos modos, el sistema político se abrió por lo menos a llenar con vida la carta de 1985, incluyendo la parte iusfundamental. En el 2005, se promulgó una Ley marco de los acuerdos de paz

19 CP de El Salvador de 1983; Acuerdos de Chapultepec de 1992; CVES, De la locura a la esperanza. 
y, en el 2008, ganó por primera vez las elecciones presidenciales la hasta entonces oposición socialdemócrata ${ }^{20}$.

Por su parte, en Ecuador y Bolivia, es difícil fechar la transformación de modo exacto. La misma no puede identificarse simplemente con la convocatoria a las elecciones en 1979 y 1982, que finalizaron con dos de los numerosos gobiernos de facto. Llama más la atención que en las subsiguientes crisis políticas, no ocurrió ninguna autoproclamación de otro salvador de la patria, aunque volvió a la presidencia de Bolivia de modo electoral, entre 1997 y 2001, el cruel ex dictador Banzer ${ }^{21}$. La percepción de haber entrado en una nueva fase, se constitucionalizó más tarde, en la primera década del siglo XXI.

\section{c. Las transiciones de las demo-autocracias híbridas: Colombia y México}

Paralelamente a la caída de las dictaduras militares, ocurrieron dos transformaciones de perfil particular. Precisamente, se cayeron dos demo-autocracias híbridas ${ }^{22}$ que habían jugado con fachadas democráticas, bastante falsas, y disfrutado de una cierta credibilidad internacional.

En el caso de Colombia, se superó el régimen del estadositismo eterno que había pasado, primero, de 1949 a 1958, por el decenio dictatorial bajo dos potentados civiles y dos militares, seguido, de 1958 a 1974, por la dictadura partidaria del Frente Nacional con cuadrienios presidenciales sin competitividad democrática, para concluir, de 1974 a 1991, en una demo-autocracia híbrida -todavía con elementos de una dictadura rotativa- llamado Pos-Frente Nacional ${ }^{3}$. Desde 1986, el

\footnotetext{
20 CP de Guatemala de 1985; Decreto 52 de 2005. Véase García L., Constituciones Guatemala, pp. 56 y ss; CEH, Guatemala, Memoria del silencio, cap. 1, pp. 439 y ss.

21 Jost, Bolivien, Politisches System, pp. 114 y ss, 193 y ss, 230 y ss, 332 y ss.

22 Sobre este concepto: Marquardt, Teoría integral del Estado II, pp. 520 y ss.

23 Sobre las características: Marquardt, El anti-constitucionalismo en la historia política de Colombia, pp. 3-43.
} 
sistema se abrió paulatinamente, de modo que se consolidó, en 1991, el clima político para elaborar una nueva constitución, estimulada por los factores generales debatidos anteriormente y condiciones particulares como la evidente crisis de paz del régimen colombiano, la desmovilización condicionada de la guerrilla social del $M-19$, la presión de manifestaciones estudiantiles y una presidencia en manos del liberal abierto Gaviria (1990-1994).

En este ámbito, se dio origen a la Asamblea Nacional Constituyente, la cual contó con una participación sustancial de los que hasta entonces se habían visto excluidos y perseguidos como enemigos públicos. Dentro de este nuevo cuerpo constituyente participaron 47 personas del ámbito del ex Frente Nacional, así como 27 miembros de la hasta entonces oposición extraparlamentaria, entre ellos varios ex guerrilleros. La formación de la presidencia de la asamblea, al estilo de un triunvirato compuesto por las tres ramas predominantes del (socio-) liberalismo, el $M-19$ y el conservadurismo, promovió un clima abierto y no precondicionado por la antigua carta de 1886 . El resultado fue una de las constituciones más idealistas de su tiempo, que renovó las tendencias vanguardistas de la mitad del siglo XIX, pero con los nuevos contenidos según el espíritu de finales del siglo $\mathrm{XX}^{24}$.

De igual forma, en los Estados Unidos Mexicanos se disolvió lo que el escritor peruano Vargas Llosa llamó, todavía en 1990, la "dictadura perfecta" por camuflarse muy hábilmente. Se habla de la disolución sucesiva de un longevo régimen unipartidista que se había formado, desde la carta de 1917, con base en las élites de la revolución socio-liberal de entonces, que había transportado, en todas las elecciones presidenciales cuatrienales y sexeniales de 1917 a 1976, el sucesor con la inequívoca mayoría dictatorial alrededor del $90 \%$ al gobierno, según la

24 Al respecto: Calle, Constitución y guerra, pp. 695 y ss; Mejía \& Múnera, Constitución, democracia y Estado autoritario, pp. 84 y ss, 91; Negretto, Making Constitutions, pp. 166 y ss; Palacios \& Safford, Colombia, País fragmentado, sociedad divida, p. 615; Valencia, Cartas de batalla, pp. 205 y ss, 209 y ss. 
designación en círculos secretos sin transparencia. El partido sistémico de la revolución cambió varias veces el nombre para firmar finalmente, desde 1946, como el Partido de la Revolución Institucionalizada-PRI-. Según su estructura, fue una especie de régimen comunista sin comunismo, precisamente con una ideología socialdemócrata hasta los años 80.

La disolución ocurrió en varios pasos entre 1988 y 2000. Después de la bancarrota estatal de facto de 1982, que llevó a negociar con el Fondo Monetario Internacional a propósito de un programa de ajuste estructural, se dio, en 1988, la primera situación competitiva material en las elecciones presidenciales desde la promulgación de la constitución mexicana de 1917, lo que transformó una dictadura de partido en una demo-autocracia híbrida alrededor de un partido hegemónico -que era todavía el mismo, pero transformó su ideología hacia la derecha 'neoliberal'-. En 1989, la oposición ganó por primera vez, con la Baja California, el gobierno de uno de los Estados federados. En 1990, se inició una ola de reformas de la constitución de 1917. Cuatro años más tarde, el régimen se acercó otra vez a la bancarrota estatal y fue presionado, mediante créditos internacionales condicionados, a promulgar reformas neo-capitalistas. En 1997, el Partido Revolucionario Institucional perdió por primera vez la mayoría absoluta en la Cámara de Diputados y, en el 2000, la oposición democristiana ganó las elecciones presidenciales con Fox (2000-2006). De esta manera, México se transformó en un sistema tripartidista ${ }^{25}$.

\section{d. Sombras del pasado: la última autocracia anti-subversiva en el fujimoriato del Perú}

Con respecto a la República del Perú, una corriente optimista de narración indica que la era de las dictaduras, predominantes desde 1948, ya había terminado con la carta del "Estado

\footnotetext{
25 Sobre la transición mexicana: Merkel, Systemtransformation, pp. 220 y ss, 229, 250 y ss; Nolte, Sonderentwicklungen, p. 32; Rabasa, De la democracia hegemónica o unipartidista, pp. 303-312; Ruiz, México ¿la dictadura perfecta?; Thiery, Lateinamerika, pp. 96 y ss.
} 
social y democrático de Derecho" de $1979^{26}$. Sin embargo, en ese entonces solo se restauró el sistema electoral a manos civiles, mientras gran parte de la carta del aprismo de izquierda fue desvalorizada por gobiernos de otra identidad política que aplicaron, al igual que Colombia, un autoritarismo camuflado bajo signos del estadositismo, el decretismo ejecutivo, el derecho penal del enemigo y la militarización, estableciendo efectivamente una demo-autocracia híbrida, lo cual se justificó por el conflicto interno armado con la guerrilla maoísta Sendero Luminoso (aprox. 1980-2000). La fase más desastrosa del balance de derechos humanos fue esta, no la anterior.

Todavía en 1992, el último y más agudo de los presidentes de tipo demo-autocracia híbrida, Fujimori (1990-2000) de tendencia conservadora y económicamente 'neoliberal', realizó un autogolpe de Estado en medio de un conflicto inter-orgánico con el Congreso dominado por la oposición. Fujimori promulgó el Decreto ley de bases del gobierno de emergencia y reconstrucción nacional, por medio del cual el jefe de Estado cerraría el parlamento, transfiriéndose provisionalmente el poder legislativo y destituyendo a todos los jueces de la Corte Suprema que le representaban alguna incomodidad. Esta estrategia anticonstitucional tuvo el resultado de eliminar la constitución socioliberal de 1979, reemplazándola por la carta más conservadora de 1993. Hubo que esperar algún grado de normalización hasta las elecciones de 1995, pero en estas se perpetuó otra vez el mismo gobernante con su enfoque en la seguridad interna. Ya en 1997, Fujimori propinó el segundo autogolpe, destituyendo a los magistrados del Tribunal Constitucional que habían declarado inconstitucional la Ley de interpretación auténtica sobre la segunda reelección. Cabe anotar que en el año 2001, la Corte Interamericana de Derechos Humanos declaró esta intervención presidencial como una dura violación de las garantías judiciales, la protección judicial y los derechos políticos de los magistrados.

26 Art. 4 de la CP del Perú de 1979. 
En el año 2000, luego de la segunda polémica reelección, Fujimori fue destituido por el Congreso y casi un decenio más tarde, en el 2009, fue condenado por la Sala Penal Especial de la Corte Suprema de Justicia a 25 años de prisión por los delitos de "homicidio calificado, [...] lesiones graves [y...] secuestro agravado". Ya en el 2001, la Corte Interamericana de Derechos Humanos eliminó la ley de auto-amnistía de 1995. Al fin, debe verse la caída de Fujimori en el 2000 como la fecha clave de la entrada peruana al ECDSA. Sin embargo, la subsiguiente discusión sobre una reforma de la carta fujimorista de 1993 tan solo condujo a resultados parciales, como suprimir simbólicamente la firma del destituido en la norma suprema ${ }^{27}$.

\section{e. Las nuevas constituciones}

En general, el Estado constitucional de América Latina se recuperó exitosamente entre 1983 y 2000, lo que se manifestó en una impresionante ola de constituciones transformadoras y reformas profundas. Como cartas completamente nuevas, en las cuales las constituyentes no se fundamentaron en el texto anterior, se señalan la Constitución politica de Guatemala de 1985, la Constituição da República federativa do Brasil de 1988, la Constitución política de la República de Colombia de 1991, la Constitución de la República de Paraguay de 1992, la Constitución política del Perú de 1993, la Constitución política de la República del Ecuador de 1998 y la Constitución de la República bolivariana de Venezuela de 1999. Un alto grado de idealismo de un nuevo comienzo, se condensó especialmente en la carta colombiana de 1991. Por su parte, Argentina subrayó su herencia constitucional predictatorial por actuar dentro de la carcasa

27 Arts. 4-5 del Decreto ley 25.418 de 1992; Ley 26.657 de 1996; Resolución legislativa 009-2000-CR; Ley 27.600 de 2001. TCP, exp. 002-96-I/TC, de 3.1.1997; Corte IDH, Tribunal Constitucional vs. Perú, de 31.1.2001, FRC, C 71; Íd., Caso Barrios Altos vs. Perú, de 14.3.2001, FRC, C, 75; CSJP, SPE, Causa Fujimori, exp. AV 19-2001, de 7.4.2009, pp. 705 y ss. Cfr. Bernales, Los caminos de la reforma constitucional en el Perú, pp. 157-173; Cantón, Leyes de amnistía, pp. 285 y ss; CVR, Informe final; Echeverri \& Duque, Política y constitucionalismo, pp. 32 y ss, 196 y ss; Mähler, Wie autoritär ist Lateinamerika? p. 2; Thiery, Lateinamerika, pp. 36-65. 
de la carta del alto liberalismo de 1853, aunque bajo reformas profundas en el espíritu de la sexta ola que se normativizaron en el procedimiento de una constituyente en 1994. También México continuó con la antigua carta de 1917 que, en muchos aspectos, fue todavía la de 1857 , pero bajo una variedad de ajustes a las temáticas del ECDSA -desde 1990, se cuenta un total de 122 reformas-. De igual forma, la gran reforma dominicana de 1994 no rompió con el cuerpo básico proveniente de 1844. En Bolivia, se reformó la carta de 1967 en 1994 y en el Uruguay, se actualizó la carta de 1967 especialmente por la gran reforma de 1996, pero también en 1989, 1994 y $2004^{28}$.

En cambio, Chile se contentó con una mera reforma parcial de la carta pinochetista en 1989 que derogó lo más incompatible con un régimen demo-constitucional, en concordancia con el carácter pactado de la transición sistémica, de modo que el país austral conservó durante quince años adicionales, hasta la gran reforma de 2005, varios enclaves autocráticos. También Panamá mantuvo la carta dictatorial de 1972 bajo la adaptación básica a una democracia pluralista en $2004^{29}$.

28 CP de Guatemala de 1985; CP de Brasil de 1988; CP de Colombia de 1991; CP de Paraguay de 1992; CP del Perú de 1993; CP del Ecuador de 1998; CP de Venezuela de 1999; CP de Argentina de 1994; Cámara de Diputados, Reformas constitucionales por decreto en orden cronológico; CP de la Rep. Dominicana de 1994; CP de Bolivia de 1995; CP de Uruguay de 1989/1994/1996; Comp. Bos, Verf.gebung u. Systemwechsel, p. 120; Brewer, Historia constitucional de Venezuela II, pp. 149 y ss, 164 y ss; Íd., Reflexiones críticas, pp. 171-193; Cunha, Do constitucionalismo brasileiro, pp. 270 y s; Echeverri \& Duque, Política y constitucionalismo, pp. 86 y ss, 107 y ss; Ferreyra, Notas sobre derecho constitucional y garantías, pp. 453 y ss; García, Constituciones Guatemala, pp. 56 y ss; Gargarella, La sala de máquinas, pp. 270 y ss; Gros \& Esteva, Constituciones Uruguay, pp. 160 y ss; Jaramillo, Constitución, democracia y derechos, pp. 28 y ss; Lorenzo, Manual de historia constitucional argentina III, pp. 429 y ss; Mejía \& Múnera, Constitución, democracia y Estado autoritario, pp. 80-108; Negretto, Making Constitutions, pp. 195 y ss; Nolte, Verf.populismus u. Verf.wandel, pp. 1-7; Olano, Constitucionalismo histórico, pp. 313 y ss; Sagüés, Constituciones Argentina, pp. 57 y ss; Serna, La reforma del Estado, pp. 29 y ss, 41 y ss, 129 y ss; Silva, Constituciones Brasil, pp. 43 y ss; Silvero, Die Verf. Paraguays, pp. 610 y ss; Valencia, Cartas de batalla, pp. 212 y ss; Vergottini, Las transiciones constitucionales, pp. 216 y ss; PNUD, La democracia en América Latina.

29 Leyes chilenas 18.825 de 1989 y 20.050 de 2005; CP de Panamá de 1994. Cfr. Casal, El constitucionalismo, pp. 217 y ss; Couso, Constitutional Law in Chile, pp. 40 y ss; Cumplido C., Reforma constitucional, pp. 105-113. 
Dentro del constitucionalismo iberoamericano en y alrededor de los años 90, se manifestó un cierto grado de influencia de las cartas vigentes en Europa occidental, especialmente la italiana de 1947 y la federal alemana de 1949, incluyendo la respectiva teoría constitucional. Un transmisor importante fue -por primera vez- una constitución española, la pos-dictatorial de 1978, que había adoptado y concentrado varias tendencias europeas de la era posterior a la Segunda Guerra Mundial. Por otra parte, pudo reconocerse una influencia significativa del constitucionalismo global de las Naciones Unidas de 1966, en particular en materia de derechos humanos de la segunda y tercera generación. De todas maneras, el constitucionalismo iberoamericano de la sexta ola adoptó de nuevo un carácter familiar propio que fue tendencialmente más idealista que el constitucionalismo europeo, en vista de su amplia orientación social, ambiental y cultural.

Una segunda sub-ola de la profundización transformadora, se desarrolló a finales del primer decenio del siglo XXI. En dos países andinos hubo descontentos con los fuertes elementos 'neoliberales' en las normas supremas de los años 90, de modo que nacieron la Constitución de la República del Ecuador de 2008 y la Constitución política del Estado plurinacional de Bolivia de 2009, ambas acentuadamente idealistas en términos de la justicia social, ambiental y étnica ${ }^{30}$.

\section{f. El enfrentamiento crítico con el pasado reciente}

En la era del ECDSA, las repúblicas hispanoamericanas subrayaron su identidad asumida por distanciarse pública y transparentemente de la anterior era anti-constitucional. Se construyeron comisiones de verdad para investigar los hechos traumáticos del pasado reciente, así por ejemplo en Argentina en 1983, en Chile en 1990 y 2003, en El Salvador en 1992, en

30 CP del Ecuador de 2008; CP de Bolivia de 2009. Véase Grijalva, Constitucionalismo en
Ecuador, pp. 25 y ss. 
Guatemala en 1994 y en Perú en 2001, que publicaron los respectivos informes para educar al demos sobre los excesos de los gobernantes anteriores ${ }^{31}$. No obstante, resultó difícil el trabajo en la memoria colectiva, pues persistieron paralelamente los mitos de los presumidos salvadores con la mano dura: no solo el actual presidente brasileño rinde homenaje a los dictadores.

\section{g. La democratización material y la apertura para los anteriormente perseguidos}

En la sexta ola, se normalizó la relación entre derecha e izquierda a una competitividad de tipo democrático. El ECDSA sumió la habilidad a traslados electorales y pacíficos del poder entre corrientes ideológicas diferentes sin intervenciones a la fuerza.

El concepto de derecha se aplicó ahora, a diferencia del uso europeo de la palabra para los nacionalistas acentuados, en el sentido de partidos que, por una parte, representaron la élite aristo-burguesa proveniente de la sociedad republicana del siglo XIX y, por otra parte, se identificaron con políticas económicamente 'neoliberales'. Inicialmente, esta corriente tuvo una ventaja, pues a finales de la Guerra Fría, los EE.UU. y sus aliados lograron transformar los respectivos conceptos en el llamado Consenso de Washington de 1989 como el fundamento ideológico de las instituciones financieras internacionales ubicadas en la capital estadounidense, que condicionaron la entrega y prolongación de créditos públicos a la sumisión a los deseos políticos del anarco-capitalismo, como la desconstrucción de la dirección estatal en la economía, la limitación de las prestaciones sociales, las privatizaciones de los servicios y empresas públicas, el neo-extractivismo, el comercio libre, la apertura para inversionistas extranjeros y la 'flexibilización' laboral. Empezó una ola de trasplantes jurídicos al nivel sub-constitucional con

31 P. ej., CONADEP, Nunca más; CVES, De la locura a la esperanza; CEH, Memoria del silencio; CVR, Informe final. 
contenidos no creados por la ciencia jurídica, sino diseñados por una corriente ideologizada de su hermana económica ${ }^{32}$. Sin embargo, muchos soberanos democráticos desarrollaron rápidamente una consciencia para las discrepancias entre las promesas doradas y los resultados pobres, por ejemplo, en vista de la disminución efectiva de las tasas de crecimiento, hasta el sufrimiento de fracasos traumáticos como el colapso de la economía argentina en la crisis de 1998 a 2002.

Por lo tanto, no sorprende que el decenio de superioridad de la derecha neo-capitalista fuera sucedido por el decenio de la ventaja de la izquierda demo-social bajo signos anti-oligárquicos y anti-imperialistas. La apertura sistémica para ellos, tuvo un alto significado transformador, pues el combate antiizquierda había sido un elemento central de los decenios del anti-constitucionalismo -cuando el anti-comunismo de raíz estadounidense los estigmatizó, mientras la élite aristo-burguesa se aprovechó para frenar la anunciada pérdida de su tradicional exclusividad frente a nuevos partidos de masas-. Así, se materializó un desarrollo previsible desde la fase fundadora de la democracia social en la cuarta ola (1917-1949). Precisamente, asumieron variantes de la izquierda intra-sistémica las presidencias en Costa Rica de 1994 a 1998 y desde 2010, en Venezuela de 1999 hasta hoy, en Chile de 2000 a 2010 y de 2014 a 2018, en el Perú de 2001 a 2006 y de 2011 a 2016, en Brasil de 2003 a 2016, en Argentina de 2003 a 2015 y desde 2019, en Uruguay de 2005 a 2019, en Bolivia de 2006 a 2019, en Honduras de 2006 a 2009, en Ecuador y Nicaragua desde el 2007, en Guatemala y Paraguay de 2008 a 2012, en El Salvador de 2009 a 2019 y en México desde 2018. En ello, el espectro se diversificó entre una izquierda relativamente centrista en Chile o Costa Rica y su hermana más idealista en Argentina, Bolivia, Ecuador, Nicaragua y Venezuela. Tampoco los gobiernos de izquierda que usaron etiquetas de un nuevo socialismo, promovieron la transformación

32 Vid. Burgos, Estado de Derecho y globalización, pp. 97 y ss; Llinás, ¿Derecho público multinacional y anti-constitucional? pp. 191 y ss, 197 y ss, 215 y ss. 
en sistemas consejistas de corte cubano, sino que se basaron en la democracia electoral con prioridad de políticas sociales ${ }^{33}$.

Desde 1990, los partidos post-oligárquicos ganaron por lo menos un periodo presidencial en todos los países de la zona, menos Colombia. Tampoco se impidió el ascenso de ex guerrilleros a la presidencia, como subrayan los casos de Ortega en Nicaragua (desde 2007), Mujica en Uruguay (2010-2015), Rousseff en Brasil (2011-2016) y Sánchez en El Salvador (2014-2019). Con la posibilitación tranquila de estos traspasos de poder, América Latina subrayó la superación material del unilateralismo ideológico de la quinta fase. No obstante, tres países se resistieron esencialmente a la competitividad material: en Paraguay, el partido oligárquico del dictador Stroessner -llamado Coloradocontinúa electoralmente en el poder -con la mera interrupción breve de 2008 a 2013-, mientras en Colombia se prolonga ininterrumpidamente la hegemonía de los partidos derechistas del régimen frentenacionalista y estadositista -hasta 2002 bajo sus nombres históricos y desde entonces en forma de partidos hijos de otras denominaciones sin perfil novedoso-; además, Honduras perpetúa el bipartidismo nacional-liberal hasta la fecha, pues frenó violentamente la breve desviación hacia la izquierda moderada de 2006 a 2009.

\section{Tendencias en el equilibrio horizontal y vertical de poderes}

El ECDSA de la sexta ola latinoamericana restauró la separación horizontal, funcional y tridimensional de poderes con controles equilibrados -desafiada o eliminada en la fase anterior-, basándose de nuevo en las tradiciones propias de dos siglos de trayectoria, y renovando, en el núcleo, la interacción política según el modelo 'dualista' entre un Presidente acentuado y un Congreso fuerte. Sin embargo, Venezuela retomó adicionalmente la antigua idea de Simón Bolívar de ampliar

33 Véase p. ej. Echeverri \& Duque, Política y constitucionalismo, pp. 28 y s, 37 y ss, 54 y ss. 
el modelo tridimensional, introduciendo en la carta de 1999 el cuarto poder ciudadano alrededor del Consejo Moral Republicano y el quinto poder electoral ${ }^{34}$.

\section{a. La cuestión de la reelección presidencial}

Una de las grandes controversias de la sexta ola se refirió a la modificación de la tradicional prohibición de la reelección inmediata del Presidente, pues se intensificaron intentos a superar este elemento clave del anti-caudillismo latinoamericano con una larga trayectoria proveniente del siglo XIX. Según el argumento de posibilitar mayor estabilidad y continuidad gubernamental, abrieron la oportunidad para repetir inmediatamente un segundo turno: el Perú en 1993, Argentina en 1994, Brasil en 1997, Venezuela en 1999, Colombia en 2004, Ecuador en 2008, Bolivia en 2009 y, finalmente, Honduras en $2015^{35}$.

Sin embargo, la reforma constitucional peruana del año 2000 prohibió nuevamente la reelección inmediata luego de que el Presidente Fujimori (1990-2000) había impuesto su segunda reelección mediante una oscura Ley de interpretación auténtica (1996) y en vista de su autogolpe contra la anulación judicial de esta ley $(1997)^{36}$. De igual forma, la Corte Constitucional de Colombia subrayó los límites inmanentes al ciclicismo democrático en 2010, prohibiendo la segunda reelección del mandatario Uribe a causa de varias irregularidades en la iniciativa normativa, mientras la reforma constitucional de 2015 restableció

\footnotetext{
34 Cap. IV-V CP de Venezuela de 1999. Vid. Echeverri \& Duque, Política y constitucionalismo, pp. 42 y s, 108 y ss.

35 P. ej., art. 112 de la CP del Perú de 1993; art. 90 de la CP de Argentina de 1994; art. 230 de la CP de Venezuela de 1999; Acto legislativo colombiano 2 de 2004. Véase Casal, El constitucionalismo latinoamericano, p. 222; García, Sobre la problemática constitucional en el Perú, p. 199; Landau, Abusive Constitutionalism, pp. 200 y ss; Mejía \& Múnera, Constitución, democracia y Estado autoritario, p. 104; Romero, La puerta alterna, pp. 527, 541 y s; Sagüés, Constituciones Argentina, p. 129.

36 Ley 27.365 de 2000, con respecto a la Ley 26.657 de 1996. TCP, exp. 002-96-1/TC, de 3.1.1997,
} 
la prohibición de la reelección como tal ${ }^{37}$. Tampoco México quiso abandonar su prohibición de la reelección establecida en la carta de 1917. Sobre el tema se dieron en muchos países polémicos enfrentamientos que subrayaron la sensibilidad de la tradición del anti-caudillismo que pretende prevenir tendencias autocráticas.

En última instancia, experimentaron con la reelección ilimitada Venezuela, Nicaragua, Ecuador, Bolivia y Honduras. En primer lugar, se perpetuó, a través de la Enmienda 1 de 2009 y el apoyo de la justicia constitucional, el gobierno caraqueño de Chávez (1999-2013) y su sucesor; segundo, siguió la jefatura managüense de Ortega (desde 2006) mediante una sentencia constitucional de 2009 -que declaró inaplicable la respectiva prohibición explícita de la carta- y la reforma constitucional 2014; tercero, una enmienda de 2015 quiso prolongar así el mandato quiteño de Correa (2007-2017), pero después de la renuncia voluntaria a usar esta posibilidad, el referéndum de 2018 eliminó la reelección indefinida; cuarto, Morales de Bolivia (2006-2019) logró, a través de la interpretación del Tribunal Constitucional de 2013, que no contó el primer periodo debido al reemplazo de la constitución -en 2009-, pero el mandatario perdió por poco el referéndum constitucional sobre otra reelección en 2016, lo que el Tribunal Constitucional no aceptó y elevó, en 2017, la reelección indefinida al rango de un derecho político inalienable, en caso de la respectiva voluntad electoral del soberano; no obstante, la reelección del 2019 fue frenada por un golpe militar ante la controversia sobre la necesidad de una segunda vuelta. De igual forma, en Honduras los jueces de la sala constitucional declararon inconstitucional la constitución, permitiendo la reelección indefinida en beneficio del conservador Hernández en 2015.

Excepto Honduras, los ejemplos tenían en común el carácter de gobiernos de corte izquierda con ambiciones idealistas

37 CCC, C-141/10; Acto legislativo colombiano 2 de 2015. 
y respaldo popular que no quisieron perder su potencial de reforma por el abandono de su caballo de desfile. Percibieron que la prohibición de la reelección sirvió, en efecto, para estabilizar la posición fácticamente privilegiada de la tradicional élite por impedir cambios significativos del status quo durante los breves cuadrienios que llevan, en realidad, a una línea eterna de personajes semejantes que solo ascienden brevemente por encima de la 'hermandad' político-económica de los oligarcas beta para alinearse, solo poco después, de nuevo a la camarilla congresista. Por lo tanto, es dudoso el argumento opositor que registra un neo-autrocratismo, pues las elecciones materialmente libres son irreprochables, teniendo en cuenta que partidos populares incluso no disponen de recursos financieros para manipular elecciones tan eficazmente como los aristo-burgueses; tampoco convence el argumento de un presidencialismo populista, pues reflejar las ideas del pueblo -y no solo de la clase empresarial- es la idea conceptual de la democracia $^{38}$

La perspectiva comparada ayuda a guardar las proporciones, teniendo en cuenta que Finlandia, Francia y Alemania han visto reelecciones consecutivas hasta 25 años del Presidente Kekkonen (1956-1981), 14 años del Presidente Mitterand (1981-1996) y tres Cancilleres federales fueron elegidos por cuatro cuadrienios -Adenauer (1949-1963), Kohl (1982-1998) y Merkel (2005-2021)-, en lo que nadie debe pensar que el poder del alfa ejecutivo de un sistema parlamentario sería menor. Parece evidente que América Latina se mueve por debajo del caudillismo institucional permitido y practicado en nombre de la estabilidad en algunos países europeos.

38 Enmienda 1 a la CP de Venezuela de 2009; CSJN, SC, sent. 504, exp. 602-09, de 19.10.2009; art. 146 de Ley 854 nicaragüense, reforma parcial de la CP de 2014; TCPB, sent. 003, exp. 02856-2013-06-CCP, de 25.4.2013; TCPB, sent. 0084/2017, exp. 20960-201742-AIA, de 28.11.2017. Véase Echeverri \& Duque, Política y constitucionalismo, pp. 44 y s; González, El autoritarismo latinoamericano en la 'era democrática', pp. 9-31; Vargas, La reelección presidencial, pp. 143-166; Viciano \& Moreno, Cuando los jueces, pp. 165-198. 


\section{b. La superación del estadositismo}

Entre los fines primordiales del constitucionalismo de la sexta ola, se indica la superación de la plaga del estadositismo abusivo que había servido, en los decenios anteriores, como el instituto estándar del anti-constitucionalismo autocrático, instrumentalizado para invalidar tanto la separación de poderes como los derechos fundamentales, haciendo de la excepción la regla y de la regla -el orden constitucional- la verdadera excepción. En particular, la Constitución de Colombia de 1991 rompió con el estado de sitio casi eterno en este país entre 1949 y 1991, limitando el periodo permitido a un término de 90 días con la posibilidad de prorrogarlo por dos periodos iguales, vinculando los decretos ejecutivos a la superación de la crisis concreta, prohibiendo la suspensión de los derechos fundamentales, eliminando la justicia penal militar frente a civiles, garantizando el funcionamiento normal de las demás ramas del poder público, e introduciendo el control inmediato de los decretos ejecutivos por parte de la Corte Constitucional. En la fase inicial de la transformación, la Corte actuó con reservas, pero anuló por primera vez un estado de sitio en 1995. De manera aun más decisiva, la Corte Constitucional declaró inexequible el decreto legislativo que buscaba una segunda prórroga del estado de conmoción interior durante el primer periodo presidencial de Uribe en 2003, así como al año siguiente el Estatuto antiterrorista del mismo mandatario -eliminando, de tal manera, un intento oscuro de reanimar el ius barbarum represivo de la anterior Guerra Fría ${ }^{39}$-.

Por su parte, la reforma constitucional chilena de 2005, atenuó las normas autocráticas de la era de Pinochet sobre los distintos estados de excepción. En ello, limitó el tiempo normal a 15 días con una sola prolongación, mitigó la profundidad de intervención, aumento el control institucional y mejoró el

39 Tít. 7 cap. 6 de la CP de Colombia de 1991; CCC, Sent. C-327/03; CCC, Sent. C-816/04. Comp. Uprimny, La judicialización de la política, pp. 47 y ss; Valencia V., Cartas de batalla, p. 23. 
control judicial, pero sin salir del esqueleto de la carta de raíz dictatorial y sin adecuar la ley orgánica de $1985^{40}$.

Desde el 2019, ante la ola transnacional de protestas sociales que criticaron, principalmente, la tensión irresuelta entre la democracia oficial y la injusticia social a gran escala, Colombia evitó la vuelta al estado de sitio, pese a que el Presidente emitió un oscuro decreto indirecto que autorizó a los alcaldes a tomar medidas análogas. Sin embargo, en países como Chile bajo Piñera, Bolivia bajo Áñez y Ecuador bajo Moreno, se pudo observar una preocupante tendencia al neo-estadositismo extensivo.

\section{c. La reanimación de la tarea normativizante del poder legislativo}

Una tendencia complementaria en el equilibrio de poderes, fue la reconstrucción y consolidación de la tarea legislativa en manos de los Congresos, revocando el anti-parlamentarismo de la fase del anti-constitucionalismo que había clausurado los Congresos por completo -en Argentina de 1976 a 1982, en Chile de 1973 a 1990 y en Uruguay de 1973 a 1985- o había transferido por lo menos la función normativizante al poder ejecutivo -así en Colombia, donde a la clausura dictatorial de 1949 a 1958 habían seguido tres decenios sin actividad legislativa de mayor impacto-. Por ejemplo, mientras la ley ambiental de Colombia de 1974 había sido expedida a través de un decreto presidencial, de habilitación genérica por parte del Congreso, su sucesora de 1993 fue una ley parlamentaria. Cabe destacar que la revitalización de los Congresos iberoamericanos se refiere al núcleo de las decisiones normativas primarias, mientras la delegación de la concreción de los detalles técnicos en la rama ejecutiva, parece una normalidad extendida en los Estados industriales modernos. Entre las excepciones de dicha tendencia general, se indica Venezuela, donde el chavismo usó varias leyes habilitantes

\footnotetext{
40 Arts. 39-45 de la CP de Chile (versión de 2005). Cfr. Williams, Causales para decretar el estado de excepción.
} 
según el artículo 203 de la constitución para gobernar mediante decretos, aprobadas en 1999, 2000-2001, 2007-2008, 2010-2012, 2013-2014 y 2015.

\section{d. Impeachment y otros conflictos inter-orgánicos}

El juicio ante el senado o impeachment no fue nada nuevo en el constitucionalismo iberoamericano -ya existía en la constitución colombiana de 1821-, pero en la década de 1990 se inició una fase en la cual los Congresos usaron con mayor autoestima esta modalidad de la justicia parlamentaria sobre el Presidente por delitos del mismo. Es un buen indicador para la vuelta al dualismo del modelo presidencialista en vez de la subordinación parlamentaria en la quinta fase.

Precisamente, resultaron destituidos por el juicio de revocación cuatro Presidentes después de haber introducido reformas 'neoliberales' impopulares que llevaron a reproches de malversación y prácticas corruptivas. Se trató de Collor de Mello de Brasil en 1992 -condenado a la pérdida del mandato y a la inelegibilidad por ocho años-, Pérez de Venezuela en 1993 -condenado a la destitución y 28 meses de arresto domiciliario, pero se escapó al asilo en EE.UU.-, Bucaram del Ecuador en 1997 -destituido por incapacidad mental, pero se escapó al exterior- y Fujimori del Perú en 2000 -por vacancia presidencial después de su huida preventiva-. Sin usar las formas del impeachment, en 2005, el Congreso ecuatoriano destituyó al Presidente Gutiérrez, utilizando el argumento del "abandono de cargo" según los términos del artículo 167 de la constitución de 1998 -aunque parece delicado subsumir una mala política dentro de la categoría del abandono-. Además, en 1999, renunció el Presidente paraguayo Cubas Grau ante la amenaza con el juicio parlamentario -en vista de denuncias de corrupción y asesinato de su propio vicepresidente- ${ }^{41}$.

41 Kada, Impeachment as a Punishment, pp. 113-136; Llinás, ¿Derecho público multinacional y anti-constitucional? pp. 202, 209; Pérez, Presidential Impeachment, pp. 15 y ss, 18 y ss, 24 y ss, 
Cabe destacar que, a veces, se manifestaron actuaciones muy grises entre el de juicio ante el Senado y un golpe de Estado. En ello, los golpes se caracterizan por ser sucesiones inconstitucionales que pueden identificarse por no cumplir con el procedimiento y los requisitos del juicio parlamentario, en particular, por no autolimitarse al requisito de juzgar delitos de peso que es inmanente a la lógica del sistema presidencialista, que no conoce la mera moción de censura del parlamentarismo europeo. En el siglo XXI, surgieron estos golpes blandos o postmodernos que buscaron derrocar a un Presidente por impeachment abusivo sin la teatral violencia castrense ahora desprestigiada. En particular, Congresos descontentos en manos de la respectiva burguesía derechista, destituyeron a dos gobernantes de la izquierda, Lugo del Paraguay en 2012 y Rousseff de Brasil en 2016, pese a que el constitucionalismo de corte presidencialista no permite ninguna destitución por meros desacuerdos políticos, ya que los delitos no fueron comprobables ${ }^{42}$.

Otras modalidades de soft coup con participación del respectivo Congreso o partes del mismo pudieron observarse en Honduras y Bolivia. Ni siquiera buscó respetar la forma del impeachment, la destitución del Presidente Zelaya de Honduras (2005-2009) de tendencia socio-liberal, ejecutado después de tensiones del mandatario con el Congreso Nacional al estilo de un secuestro militar con una renuncia fingida y leída en el Congreso que llevó al nombramiento parlamentario de un oponente como sucesor de facto $^{43}$. El hasta entonces último caso de golpe postmoderno ocurrió en Bolivia en 2019, donde las fuerzas militares presionaron al longevo Presidente Morales a la renuncia, con el efecto de que una minoría parlamentaria sin quórum -bajo la ausencia forzada de la mayoría de dos tercios del partido

42 Respecto a los casos: Anderson et al., Golpe en Brasil; Dinerstein, Impeachment or 'Soft Coup'; Echeverri U. \& Duque A., Política y constitucionalismo, p. 67; Huertas \& Cáceres, Los golpes de Estado constitucionales en Latinoamérica, pp. 28-35; Ríos, Tres etapas del golpe 'blando' en Brasil, pp. 183-204.

43 Cfr. Nolte, Verf.reformen u. Verf.krise, pp. 28-45; Peetz, Honduras, Von einem Militärputsch, pp. 1-8. 
presidencial- eligiera a una sucesora de facto, precisamente a la segunda vicepresidenta del Senado Áñez que perteneció a la oposición de la derecha oligárquica, clerical y racista ${ }^{44}$.

De todos modos, el conflicto inter-orgánico más dramático se desarrolló en Venezuela a partir de las elecciones parlamentarias para 2016, cuando la oposición burguesa venció la estable mayoría absoluta del socialismo desde 2000 e inició una política ofensiva de destronar al Presidente socialista Maduro -electo en 2013 y reelecto en 2018-. Ante estas tensiones, en 2017, el Presidente llevó a cabo un auto-golpe, derrocando al parlamento por transferir sus competencias a una asamblea constituyente de bolsillo -electa, pero de composición cuasi unipartidista, pues los partidos de la oposición decidieron marginarse-, lo que reemplazó fácticamente la separación de poderes por la unidad de poderes, basándose en la finalidad de salvar la revolución chavista. Por su parte, en enero de 2019, el presidente del parlamento paralizado se auto-proclamó Presidente 'interino' del país con una abstrusa justificación seudo-constitucional que afirmó, en contra de toda realidad, la vacancia presidencial, en lo que recibió el apoyo de EE.UU. y diversos países aliados por un reconocimiento intervencionista -que es ilegal según los estándares del derecho internacional público ${ }^{45}-$, pero este intento de un golpe de Estado internacionalmente respaldado fracasó. Factores como la dependencia unilateral de la exportación del petróleo -proveniente de la era puntofijista- y los barrios pobres más extensos de América Latina -con un origen en la misma época-, junto con la política estadounidense de

\footnotetext{
44 Para el turno vigente de 2015 a 2020, la legitimidad democrática del MAS fue: Presidente Morales 63,4 \%, Cámara de Representantes 67,7 \%, Senado 69,4 \%. La crisis empezó con la afirmación estratégica de la oposición derechista de un supuesto fraude electoral en las elecciones del 2019 (turno a partir de 2020), según el cual el ganador reelecto Morales $(47,1 \%)$ hubiera evitado irregularmente una segunda vuelta electoral (la controversia se refirió a la ventaja requerida del 10 \%), lo que nadie logró comprobar (aparte de las irregularidades menores que aparecen en casi toda elección latinoamericana), pero la comisión de la OEA - de mayoría derechista- quiso echar leña al fuego por publicar insinuaciones ambiguas de eventualidades. No se logró resolver esta crisis de modo constitucional-democrático.
}

45 Se pueden reconocer países pero no gobiernos. 
inanición, echaron leña adicional al fuego conflictivo. En el momento de la escritura de este párrafo, el orden constitucional está disuelto y solamente es controvertible si Venezuela representa un fracaso trágico de un conflicto inter-orgánico, una demo-autocracia híbrida o una dictadura social, sin olvidar que en este escalado nadie de los participantes haya preservado un historial limpio ${ }^{46}$.

En síntesis, en los grandes conflictos inter-orgánicos de la historia reciente, se impuso típicamente el Congreso -excepto Venezuela-, es decir, el derrumbe de la confianza parlamentaria llevó normalmente a la destronización del mandatario -con medios constitucionales, fronterizos o extraconstitucionales-, lo que se jugó habitualmente según las disconformidades ideológicas en el binario izquierda-derecha y las fuerzas societales de fondo -populismo vs. oligarquismo-, aparte de elementos adicionales como enemistades personales e intrigas de palacio. Ante estos conflictos, el observador debe tener cuidado con simpatías sumarias para el ejecutivo o el legislativo, teniendo en cuenta las particularidades de los países, actores y dinámicas.

\section{e.La tercera rama agilizada: el garantismo judicial}

El reacomodamiento del equilibrio de poderes en la sexta ola, benefició también al poder judicial al estructurarlo en una variedad de altas cortes de justicia que incluían típicamente tribunales constitucionales especializados o salas constitucionales dentro de las cortes supremas. En ello, el elemento más innovador fue la transición de las mentalidades hacia el juez crítico, creativo y materialmente independiente que actuó cada vez más bajo la disposición de tomar las decisiones jurídicamente correctas aun cuando fueron políticamente incómodas.

\footnotetext{
46 Vid. Brewer C., Reflexiones sobre la dictadura, pp. 177-216; Kurtenbach, Venezuela, pp. 1-13; Weisbrot \& Sachs, Sanciones económicas como castigo colectivo, Venezuela; Tirado S., Venezuela, Más allá de mentiras y mitos.
} 
a. La activación de la justicia constitucional protectora e influyente

El elemento de mayor impacto fue el ascenso de la justicia constitucional al papel de un actor clave del sistema de poderes bajo la adopción material del papel del guardián y defensor de la constitución. No fue novedoso el concepto como tal, pues el amparo constitucional se basó en una antehistoria a partir de Cundinamarca en 1811 y Yucatán en 1841, pero antes de la sexta ola, la justicia constitucional había mostrado típicamente una tendencia pasiva y sumisa, anticipando preferiblemente las expectativas del respectivo gobierno. De tal manera, las funciones de control se habían limitado al disciplinamiento esporádico de Estados federados en manos de la oposición y a asuntos no tan controvertidos en términos políticos. Además, en la era del anti-constitucionalismo, las altas cortes habían dado su visto bueno al estadositismo notorio y habían colaborado en la persecución de los supuestos enemigos públicos en vez de defender los derechos de aquellos.

En la era del ECDSA, diversas repúblicas crearon tribunales constitucionales especializados, separados de las cortes supremas. Preguntando por las inspiraciones, puede señalarse, por una parte, el diseño básico del patrón austríaco de 1920 y alemán de 1951, pero sin subestimar que hubo también modelos iberoamericanos anteriores a la sexta ola, en particular, el precursor cubano (1940-1952), así como Ecuador (1945-1946, desde 1967), Chile (1970-1973) y Perú (desde 1979). Entre los ejemplos nuevos pueden mencionarse la Corte de Constitucionalidad de Guatemala de 1985, el Tribunal Constitucional de Chile (desde 1989), la Corte Constitucional de Colombia de 1991 y el Tribunal Constitucional de Bolivia de 1998. Otros Estados dejaron permanecer la justicia constitucional en una sala particular de la Corte Suprema, por ejemplo Argentina, Brasil, Costa Rica, México y Venezuela. La ventaja de la corte constitucional especializada se reveló en combinación con la transición sistémica, pues así se abrieron perspectivas aumentadas de romper 
con la path dependency establecida: mientras en las cortes supremas continuaron los jueces del régimen anterior, entró al nuevo guardián de la constitución una renovada generación de juristas, muchas veces reclutada de los críticos y víctimas del sistema anterior, lo que pudo provocar un enfrentamiento entre las altas cortes, pero el mismo aumentó las oportunidades de implementar el pensamiento pro-iushumano ${ }^{47}$.

Entre las competencias típicas, la más relevante era la protección de los derechos fundamentales. Algunas veces, se mejoraron las opciones de defensa de los mismos a través de nuevos recursos acelerados y de fácil manejo como la acción de tutela colombiana, con la cual el ciudadano puede "reclamar ante los jueces, en todo momento y lugar, mediante un procedimiento preferente y sumario [...] la protección inmediata de sus derechos constitucionales fundamentales, cuando quiera que éstos resulten vulnerados o amenazados por la acción o la omisión de cualquier autoridad pública" y solo hay "diez días entre la solicitud de tutela y su resolución" ${ }^{48}$. En comparación con los recursos de amparo constitucional de Europa, esto fue revolucionario en términos de eficiencia y velocidad, lo que se justificó por el alto nivel de transgresiones que las autoridades habían aprendido en los decenios anteriores. En realidad, la tutela ascendió al recurso más estimado por el pueblo del país en mención ${ }^{49}$.

De todos modos, en muchos Estados iberoamericanos se inició un cambio significativo del papel de las altas cortes en el equilibrio de poderes, cuando los respectivos magistrados

\footnotetext{
47 Arts. 268 y ss de la CP de Guatemala de 1985; arts. 81 y ss de la CP de Chile de 1980/1989; arts. 116, 239-245 de la CP de Colombia de 1991; Ley boliviana 1.836 de 1998. En Chile, la carta de 1980 previó el Tribunal Constitucional, pero el mismo no fue realizado materialmente durante la dictadura. Cfr. López, La justicia constitucional colombiana, pp. 74 y ss, 82 y ss; Lösing, Verf.gerichtsbarkeit, pp. 134 y ss; 279 y ss, 313 y ss; Nogueira, La defensa de la Constitución, pp. 187 y ss, 202, 204 y ss; Romero, Las acciones públicas de inconstitucionalidad, pp. 50 y ss, 99 y ss.
}

48 Art. 86 de la CP de Colombia de 1991.

49 En 2018: 607.308 acciones de tutela; Defensoría de Pueblo, La tutela 2018, p. 51. 
interiorizaron la idea de ser los guardianes de las normas constitucionales frente a violaciones por el gobierno, el Congreso, la administración pública o los jueces inferiores. Como el ejemplo más acentuado de la nueva creatividad, destacó la Corte Constitucional de Colombia. Ya a finales de los años 80, la anterior Corte Suprema había asumido un papel de control contra oscuridades de la era anti-constitucional, pues declaró inexequibles, en 1987, la aplicación de la justicia penal militar frente a personas civiles y, en 1989, la autorización legal del paramilitarismo ${ }^{50}$. A partir de 1991, la nueva Corte Constitucional se inspiró en la capacidad de control de la Bundesverfassungsgericht alemana y la recepción teórica por las traducciones del constitucionalista Alexy, pero superó rápidamente el nivel de actividad de su modelo. La lista de sentencias emblemáticas es larga. Por ejemplo, a partir de 1995, los guardianes de la carta controlaron los intentos abusivos de revivir los estados de sitios, rompiendo definitivamente con un elemento central de la mentalidad del anti-constitucionalismo. De igual forma, en 1997, declararon inexequibles partes del Código penal militar de 1988 bajo la idea de abolir el proteccionismo de los malhechores de la contra-insurgencia heredada, retransfiriendo la competencia para juzgar delitos contrarios a la dignidad humanidad a la justicia ordinaria, así como prohibiendo la vulneración de la igualdad punitiva por castigos menores de uniformados. En 1998, los magistrados defendieron la libertad de opinión y de información, anulando la Ley del periodista proveniente de 1975. Dos años más tarde, salvaguardaron las garantías del debido proceso contra un intento de reedición de los oscuros jueces sin rostro. Además, la Corte Constitucional de Colombia protegió en el 2004 los derechos fundamentales de la población desplazada, subrayando los deberes protectores del Estado, lo que fue un paso importante, si se evalúa la

50 CSC, SP, Sent. 20, de 5.3.1987; CSC, SP, Sent. 022, de 25.5.1989. Sin embargo, en 1997, siguió la ambigua sentencia de la Corte Constitucional que autorizo la 'seguridad privada' de los Convivir, CCC, C-572/97. 
calidad constitucional en la capacidad de proteger a los más vulnerables. El mismo tribunal despenalizó, en 1997, la ayuda a la muerte digna (eutanasia) y solucionó, en 2006, uno de los conflictos típicos de la época, la cuestión del aborto, adoptando las tendencias internacionales en el sentido de una despenalización parcial de la mujer, así similar al primer modelo alemán de 1975 a 1992 en caso de ciertas indicaciones y no por plazos generales. Los casos sociales, ambientales y étnicos se señalarán en adelante en los respectivos subcapítulos. De todos modos, la jurisprudencia frecuente de la Corte Constitucional de Colombia sobre casi cualquier asunto jurídico, cambió también la cultura jurídica, de modo que muchos jueces comunes, profesores y estudiantes citan ampliamente estas sentencias en vez de la ley o la dogmática científica ${ }^{51}$.

Asimismo, la Sala Constitucional de la Corte Suprema de Costa Rica entró, a partir de la reforma judicial de 1989, al espectro activo, creativo y protector. También otros países elaboraron sentencias impactantes, por ejemplo la Corte de Constitucionalidad de Guatemala que declaró inconstitucional, en 1993, el autogolpe de Estado del Presidente Serrano, motivando el mismo a huir de su función y país. Por su parte, el Tribunal Constitucional del Perú eliminó, en 2003, a causa de una "acción de inconstitucionalidad interpuesta por más de cinco mil ciudadanos", gran parte del oscuro derecho penal y procesal del enemigo público de la autocracia fujimorista, imponiendo de esta manera las garantías constitucionales del debido proceso y abriendo el camino para la anulación de cientos de condenas injustas ${ }^{52}$.

De las tendencias expuestas hay que exceptuar aquellas altas cortes que se caracterizan por un alto grado de influencia

51 CCC, Sent. C-466/95; CCC, Sent. C-802/02; CCC, Sent. C-358/97; CCC, Sent. C-087/98; CCC, Sent. C-392/00; CCC, Sent. T-025/04; CCC, Sent. C-239/97; CCC, Sent. C-355/06. Sobre T-025/04: Llinás, Constitución y ética constitucional, pp. 144 y s.

52 Ley costarricense 7.128 de 1989; CCG, exp. 225-93, de 25.5.1993; TCP, exp. 010-2002-Al/TC, de 3.1.2003. Cfr. Feoli, Las cortes super poderosas, pp. 136 y ss; Landa, Los ddff como límites, pp. 103-129. 
del poder ejecutivo en la composición personal, promovida en sistemas pro-reeleccionistas con longevos presidentes o en sucesiones de tipo príncipe heredero. El caso más llamativo es la Venezuela chavista con su Tribunal Supremo incluyendo la sala constitucional que apoyó con una enorme lealtad la latente autocratización bajo el Presidente Maduro a partir de $2013^{53}$.

\section{b. La justicia transicional}

Paralelamente, surgió en Iberoamérica la justicia transicional en el sentido de manejar los abusos de los anteriores gobiernos del anti-constitucionalismo a través del derecho penal. La zona fue prácticamente la precursora mundial en liderar procesos penales contra ex gobernantes responsables de macro-delincuencia estatal.

Entre los ex jefes de Estado condenados a largas penas privativas de la libertad, se encuentran tanto los dictadores argentinos Videla (1976-1981) y Viola (1981) en el marco del Juicio a las Juntas de 1985, como en 1993 el ex dictador boliviano García Meza (1980-1981). Siguieron en 2009 el ya mencionado ex mandatario del Perú Fujimori (1990-2000) y el último dictador uruguayo Álvarez (1981-1985) que recibió 25 años por 37 homicidios, además en 2010 el autogolpista uruguayo Bordaberry (1973-1976) que tuvo que pagar 30 años por atentados contra la Constitución en reiteración real con nueve crímenes de desaparición forzada y dos crímenes de homicidio político. Por su parte, el ex dictador guatemalteco Ríos Montt (19821983) resultó condenado, en 2013, a 80 años de prisión por el genocidio contra los mayas y otros crímenes de lesa humanidad, pero la Corte de Constitucionalidad anuló la sentencia por supuestas irregularidades procedimentales. El juicio sucesor se desarrolló a partir de 2015, pero no terminó, debido a la muerte natural del ex Presidente en 2018. De igual forma, el ex dictador chileno Pinochet (1973-1990) escapó de la condena esperada

53 Llanos \& Tibi, Die Justiz in Lateinamerika, p. 2. 
durante varios años de investigaciones con tácticas jurídicospolíticas hasta su muerte natural en 2006. De todos modos, a los ojos de las cortes de justicia, los auto-designados salvadores de la patria fueron simplemente asesinos y secuestradores, lo que tuvo un mayor impacto de educación popular en comparación con los reportes de las comisiones de verdad. De tal manera, la historia rechazó la acentuada figura schmittiana de la supuesta soberanía de los dictadores o señores del estado de sitio, pues, al fin, ninguno de ellos tuvo el poder de la última decisión por encima de la justicia republicana ${ }^{54}$.

En cambio, la Corte Suprema colombiana se enfocó en miembros de la rama legislativa. Después de la desmovilización paramilitar de 2005, los jueces se empoderaron al manejo punitivo de la llamada 'parapolítica', persiguiendo a múltiples miembros de la élite político-económica por la incitación y cooperación con los mortíferos ejércitos del terror pro-sistémico privatizado. En efecto, condenaron a más de 60 congresistas a penas privativas de libertad entre 2007 y 2018. Complementariamente, la justicia penal de dedicó a gobernadores, alcaldes, militares y policías que habían colaborado con la paraestatalidad mortal. En el momento de la escritura de este artículo, el periódico El Tiempo calcula al menos 250 altos funcionarios del Estado colombiano condenados ${ }^{55}$.

Sin embargo, estas tendencias punitivas compitieron en muchas repúblicas con la contra-tendencia de pacificar, en el espíritu de la tradición pactista y reintegradora del siglo XIX, por medio de amnistías e indultos ${ }^{56}$. Hasta la fecha, Brasil no

\footnotetext{
54 CNCrim, Causa 13/84; CSJN, Sentencia contra Luis García Meza y sus colaboradores; CSJP, SPE, Causa Fujimori, exp. AV 19-2001; Juzgado penal 19², Montevideo, Gregorio Álvarez et al., sent. 0157, de 21.10.2009; Juzgado penal 23\% $7^{\circ}$, Montevideo, Juan M. Bordaberry, sentencia de 9.2.2010; CCG, Caso Ríos Montt, exp. 1904-2013, de 20. 5.2013. Véase Laughland, A History of Political Trials, pp. 181 y ss; Rosales, El juicio del siglo.

55 Red. Justicia, Abren puerta; Red. Verdad Abierta, De la curul a la cárcel; Rojas, Razonamiento judicial en Colombia, pp. 379 y ss; López et al., Y refundaron la patria, pp. 29 y ss, 79 y ss, 457 y ss. 56 Cantón, Leyes de amnistía, pp. 265-291.
} 
ha anulado la ley de auto-amnistía de la dictadura militar de 1979, mientras Paraguay incluso nunca propuso ninguna ley semejante, pues bajo la continuidad del partido dictatorial en el poder, fue evidente que nadie tiene que temer nada. Además, subrayan ilustrativamente la ambigüedad de los decenios pos-transicionales, los cambios en el tratamiento penal del ex dictador argentino Videla, con dos condenas (1985, 2010), el indulto presidencial de 1990 y la muerte en la prisión en 2013.

\section{c. ¿Activismo judicial o garantismo profundo?}

En el ECDSA de la sexta ola, los tribunales y salas constitucionales obligan a las dos otras ramas de poder a anticipar en sus decisiones la probable interpretación de los derechos fundamentales por parte de los jueces. A través de la amenaza persistente con la última palabra, se juridifica la esfera política. De tal manera, no es falso advertir que el Estado del siglo XXI confía varias de sus decisiones más políticas a una especie de consejo de sabios, lo que establece un elemento aristocrático dentro del modelo de la democracia representativa. La legitimidad democrática del guardián de la constitución es solamente indirecta -excepto el Tribunal Constitucional de Bolivia con sus magistrados electos popularmente-, otorgada por el poder constituyente, por los intermediarios del procedimiento de nombramiento y por la confianza general que el pueblo expresa a los jueces máximos, pues la percepción de su moderación profesional sin intereses partidarios ni enriquecimientos corruptivos $^{57}$, los hace aparecer como los verdaderos sucesores del mito milenario de los buenos Reyes-jueces por encima del mar revuelto de lo banal de la cotidianeidad.

No sorprende que algunos gobernantes y oligarcas parlamentarios se sientan incómodos con una tercera fuerza que reclama la última decisión. Varios oponentes hablan con connotaciones desdeñosas del activismo judicial y recomiendan la auto restricción

57 Sin embargo, hay excepciones, como ilustra el escándalo del cartel de la toga colombiano. 
judicial. En parte, son argumentaciones estratégicas según intereses temáticos, pero por otra, se articula la duda general si este decisionismo no llevaría a una especie de soberanía judicial. Al respecto, no es falso señalar que el Estado de Derecho del siglo XXI ha asumido ciertos rasgos de un Estado de los jueces, pero esto no es nada malo en comparación con los peligros para la democracia constitucional que son inmanentes a aspirantes alfas y oligarcas y que se controlan a través de los jueces. Según la experiencia, las cortes constitucionales se han perfilado como las instituciones estatales menos propensas a ideologizaciones, particularidades y cortoplacismos, pues los procedimientos y la ética profesional alrededor de la ponderación cuidadosa y la argumentación racionalista se integran a un estilo consistente que protege eficazmente a los valores consagrados en la norma de normas. Los guardianes de la constitución no desvalorizan la democracia representativa, sino son un complemento comprobado y sabio de las otras dos ramas: quien toma los derechos en serio, debe entregar su protección a los jueces. La legitimidad democrática tampoco es menor a las otras dos ramas, pues todas son autorizadas por el pueblo soberano en su actuación originaria como poder constituyente y, también en términos socio-culturales, un juez que defiende derechos del pueblo muestra más credibilidad como demócrata que un congresista que se adscribe unilateralmente a intereses empresariales. Finalmente, en vez del concepto despectivo del activismo judicial, este escrito parte del garantismo judicial como un gran logro del presente ${ }^{58}$.

\section{f. Los partidos políticos}

Otro tema transversal de alto impacto en el equilibrio de poderes, fue el reconocimiento visible de los partidos políticos

\footnotetext{
58 Comp. p. ej. las discusiones en: Arenas, Participación ciudadana y activismo judicial, pp. 167 y ss.; Feoli, Las cortes super poderosas, pp. 127 y ss; Ferreyra, Notas sobre derecho constitucional y garantías, pp. 149 y ss, 249 y ss; Gargarella, Teoría y crítica del derecho constitucional, pp. 153 y ss, 318 y ss, 968 y ss; López D., La justicia constitucional colombiana, pp. 121 y ss, 189 y ss, 216 y ss.
} 
como fundamentos del proceso democrático, rompiendo con el agresivo anti-partidismo y unipartidismo durante la fase de las dictaduras. El constitucionalismo fundador del siglo XIX no los había previsto. Siguiendo las cartas cubana de 1940, venezolana de 1961, ecuatoriana de 1967 y la reforma mexicana de 1977, la Constitución de Argentina de 1994 acentuó: "Los partidos políticos son instituciones fundamentales del sistema democrático. Su creación y el ejercicio de sus actividades son libres". Con todo detalle, la Constitución de Colombia de 1991 ostentó su cuarto título sobre "la participación democrática y de los partidos políticos", aludiendo explícitamente "el estatuto de la oposición" 59 . Similar a otros países occidentales, puede caracterizarse la contemporánea democracia representativa de Iberoamérica como un Estado de partidos. Como un fenómeno paralelo de la sexta ola, el espectro de los partidos políticos se diversificó, superando definitivamente la dicotomía liberoconservadora del siglo XX, lo que incluyó el ascenso de nuevos partidos más populares y menos oligárquicos, llegando a la nueva dicotomía típica entre derecha e izquierda en sistemas pluripartidistas.

\section{g. Síntesis}

En comparación con el continente de las dictaduras y demoautocracias híbridas del año 1973 -cuando solo dos países iberoamericanos pudieron ser calificados como democracias, Costa Rica y Venezuela-, el Estado constitucional material ha logrado una victoria aplastante. En general, los sistemas de separación y equilibrio de poderes funcionan adecuadamente, sin la anterior concentración excesiva en la rama ejecutiva, pues en casi todos los lugares se observan Congresos que legislan con seriedad y tribunales que juzgan imparcialmente. Probablemente, la rama judicial iberoamericana -por lo menos en países como

59 Art. 38 de la CP de Argentina de 1994; art. 112 de la CP de Colombia de 1991. Véase Echeverri U. \& Duque A., Política y constitucionalismo, pp. 314 y ss; Vergottini, Las transiciones constitucionales, pp. 76 y ss. 
Colombia- ha ascendido a ser la más poderosa del mundo. No obstante, tampoco se logra impedir completamente las arbitrariedades parlamentarios, presidenciales o de aspirantes terceros, es decir, de vez en cuando se condensan todavía problemas serios como el impeachment abusivo en Brasil (2016), el conflicto inter-orgánico en Venezuela con dos partes que exageran (desde 2017) o el golpe de Estado en Bolivia (2019).

\section{El perfil pluralista y el triángulo de valores liberales, sociales y ambientales}

Las constituciones iberoamericanas de la sexta ola muestran típicamente un perfil pluralista de valores, combinando ahora, de acuerdo con las necesidades de la sociedad industrial avanzada, los elementos del Estado liberal del siglo XIX, del Estado social de la primera mitad del siglo XX y del Estado ecológico de finales del siglo XX, al estilo de un triángulo de valores. En otras palabras, el Estado constitucional republicano-democrático se ha transformado también en América Latina -de manera similar al escenario europeo y en contraste con EE.UU.- al Estado constitucional democrático-social-ambiental.

Cabe destacar que el pluralismo posmoderno tiene como consecuencia que la constitución misma no decide todos los conflictos entre los tres grupos de valores en eventual disputa, sino que asigna la ponderación de estos fines divergentes al campo de la política, según los resultados electorales. Por eso, sobre la base de documentos constitucionales similares, la una república realiza ideales gradualmente más socialistas, mientras la otra favorece políticas más 'neoliberales', aunque hay un límite fuerte de estas ponderaciones: deben respetar el núcleo de todo valor constitucional como inviolable. Tampoco deben subestimarse las diferencias graduales de diseño al interior del triángulo pluralista del ECDSA, dentro del cual aparecen, de manera particular, las cartas de Venezuela de 1999, de Ecuador de 2008 y de Bolivia de 2009 como los modelos de un nuevo estilo constitucional más socio-ambiental que liberal. 


\section{a. El valor nuclear transversal: dignidad humana}

Como el núcleo de los derechos fundamentales, el ius commune constitucional de América Latina se enfocó definitivamente en el término conceptual de la dignidad humana. Partiendo de su raíz en el constitucionalismo social alemán de $1919^{60}$, el mismo se había trasladado tempranamente a la constitución boliviana de 1938, a las cartas ecuatoriana y guatemalteca de 1945, a la reforma mexicana de 1946, a Venezuela en 1961 y al Perú en 1979. Finalmente, la sexta ola se centró en la misma como el meta-principio integrador del Estado iusfundamental, así los respectivos artículos 1 de las constituciones brasileña de 1988, colombiana de 1991, paraguayana de 1992, peruana de 1993 y chilena (reforma) de 2005, al igual como las cartas venezolana de 1999, ecuatoriana de 2008 y boliviana de 2009 la incluyeron en diversos lugares.

\section{b. Tendencias en la esfera liberal}

De modo introductorio, cabe anotar que el constitucionalismo contemporáneo ha confirmado los catálogos clásicos de los derechos fundamentales de tipo liberal de la primera generación, que son comprobables en Hispanoamérica en todo el bicentenario del constitucionalismo moderno a partir de 1811 . Sin embargo, la sexta ola llevó a varias profundizaciones de lo liberal que se ejemplificarán en seis subcapítulos, para terminar con una pérdida cualitativa en un cierto lugar.

\section{a. Estado de Derecho y supremacía constitucional}

En primer lugar, la sexta ola adoptó la terminología del Estado de Derecho, proveniente del Rechtsstaat en la Ley fundamental de la República Federal de Alemania de 1949. En cierto sentido había sido inmanente al principio de legalidad desde las primeras constituciones hispanoamericanas, pero los sustantivos

60 Al respecto: Marquardt, La Constitución de Weimar de 1919, pp. 74 y s. 
expresivos contienen su propia fuerza de convicción. De todos modos, hubo que romper con el Estado de medidas fácticas que había predominado en la era anti-constitucional. El concepto en mención surgió, por ejemplo, en los primeros artículos de las constituciones colombiana de 1991, paraguayana de 1992, peruana de 1993, venezolana de 1999, ecuatoriana de 2008 y boliviana de 2009 .

Otra tendencia común fue la constitucionalización explícita del rango superior de la carta en la jerarquía normativa, negando aquellas ramas del iuspositivismo que habían legitimado cualquier norma de cualquier nivel con cualquier contenido, incluyendo los decretos estadositistas a través de las cuales el anti-constitucionalismo había suprimido los derechos constitucionales sin quitarlos del texto de la carta. Entre otras, la constitución colombiana de 1991 se auto-calificó como la "norma de normas", al igual que lo precisó la venezolana de 1999: "La Constitución es la norma suprema y el fundamento del ordenamiento jurídico" 61 .

\section{b. El derecho a la vida}

En la esfera iusfundamental, la sexta ola perfeccionó la tendencia del alto liberalismo de la mitad del siglo XIX de reconocer el derecho a la vida por la abolición de la pena de muerte. Se recuerda que Venezuela (1864), Costa Rica (1877), Ecuador (1897), Panamá (1904), Uruguay (1907) y Colombia (1910 [1863-1886]) habían sido los protagonistas mundiales. Mucho más tarde, el Perú siguió con la constitución aprista de 1979 en cuanto a los delitos comunes. Después de las persecuciones mortíferas en la era dictatorial, Argentina abolió la pena de muerte por la Ley de defensa de la democracia de 1984, la constitución de 1994 y la respectiva corrección del Código de justicia militar en 2008; Paraguay lo hizo por la constitución

\footnotetext{
61 Art. 4 de la CP de Colombia de 1991; art. 7 de la CP de Venezuela de 1999. Cfr. Quinche, Derecho constitucional colombiano, pp. 68 y ss.
} 
de 1992, Bolivia en la reforma penal de 1997 y la constitución de 2009, Chile en 2001 -pero con excepciones prolongadas en tiempos de guerra- y México siguió en $2005^{62}$. En cambio, en el derecho guatemalteco y cubano, se mantiene la pena de la eliminación física de seres humanos, aunque sin aplicarla desde 2000 y 2003, respectivamente. No obstante, también en múltiples otros países sobrevive una cierta actuación mortal del Estado que no es punitiva sino policiva y militar, por ejemplo, por excesos contra manifestantes pacíficos.

\section{c. Garantías procesales penales}

Una política clave de la restauración de los derechos fundamentales liberales concernió a las garantías del imputado dentro del proceso penal, formuladas originalmente en la primera ola del constitucionalismo hispanoamericano. Hay que reconocer dos tendencias contradictorias: por una parte, fue ineludible limpiar sistemáticamente el derecho procesal penal del ius barbarum de la quinta fase, suprimiendo la multitud de normas excepcionales del estadositismo que habían sacrificado la seguridad ciudadana en nombre de la seguridad anti-terrorista, pero, por otra parte, se presentó la necesidad de superar el notorio déficit de eficiencia del aparato judicial y policial en cumplir con sus funciones básicas. En ese entonces, la Constitución de Colombia de 1991 formuló explícitamente un derecho fundamental de acceso a la justica. Sin embargo, la Ley de orden púbico de 1993 transfirió de modo sumario y poco transparente 60 decretos estadositistas en normatividad permanente ${ }^{63}$.

\section{d. Los derechos de comunicación democrática}

En cuanto a la tradición bicentenaria de la libertad de expresión, las repúblicas posautocráticas restauraron la posibilidad

\footnotetext{
62 Ley argentina 23.077 de 1984; Ley boliviana 1.768 de 1997; Ley chilena 19.734 de 2001; Decreto mexicano, reforma CP de 2005.

63 Art. 229 de la CP de Colombia de 1991; Ley colombiana 104 de 1993.
} 
material de articular y difundir cualquier tipo de opinión política, individual o colectivamente, depurando el derecho penal y administrativo de normas empleadas contra el flujo libre de las ideas.

En general, la reconstitucionalización alrededor de los años 90 promovió el ascenso de un derecho democrático de manifestaciones, por ejemplo, en forma de la Constitución de Colombia de 1991, que garantizó ahora que "toda parte del pueblo puede reunirse y manifestarse pública y pacíficamente", lo que la carta hermana de Venezuela de 1999 formuló como el "derecho a manifestar, pacíficamente y sin armas, sin otros requisitos que los que establezca la ley" ${ }^{64}$. Sin embargo, uno de los procesos de aprendizaje más difíciles fue interiorizar que las manifestaciones críticas en el espacio público no fueron agitaciones sediciosas, sino al revés elementos valiosos del proceso de formación de la voluntad colectiva en la democracia comunicativa. Una última ola de violencia feroz ocurrió frente a las protestas populares contra las incipientes reformas 'neoliberales'. El caso de mayor impacto fue la masacre venezolana del Caracazo de 1989, en la cual el ejército y la policía, bajo el mando del Presidente Pérez, causaron por lo menos 276 muertos, lo que llevó posteriormente a una condena por la Corte Interamericana en Derechos Humanos $^{65}$. En 2003, se repitió la violencia ejecutiva contra manifestantes en Bolivia, cuando el ejército cometió la masacre de octubre negro, pero los supervivientes de los manifestantes triunfaron, pues presionaron al Presidente Sánchez de Lozada a la renuncia. No obstante, todavía en la ola de manifestaciones multitudinarias en países como Chile, Colombia, Ecuador y Bolivia de 2019, pudo observarse excesos de violencia por policías que se presentaron incluso más acorazados y mejor armados que los de la era dictatorial.

Además, el ECDSA implicó el restablecimiento de la tradicional libertad de prensa sin censura, ampliada por la contraparte

\footnotetext{
64 Art. 37 de la CP de Colombia de 1991; art. 68 de la CP de Venezuela de 1999.

65 Corte IDH, Caracazo vs. Venezuela, sent. de 29.8.2002, FRC, C, 95.
} 
del derecho a recibir información. No obstante, según el ranking mundial de Reporteros sin Fronteras de 2019, solo Costa Rica y Uruguay alcanzan buenos rangos comparativos (10 y 19 de 180 países), mientras Colombia tiene que contentarse con el rango 129, México con el 144 y Honduras con el 146, en lo que los problemas se trasladaron de actividades del personal estatal a la omisión por no garantizar ninguna seguridad mínima frente a amenazas por 'desconocidos', aparte de la autocensura impuesta por múltiples propietarios frente a sus reporteros ${ }^{66}$.

El constitucionalismo de la sexta ola tendió a tratar los medios de comunicación masiva -como la televisión, que se había difundido desde los años 50- de modo conecto con la libertad de prensa, pero tendió a transferir ambos juntamente a los derechos socio-económico y culturales -la carta boliviana de 2009 habló de la "comunicación social"-67. En Colombia, la legislación televisiva de 1995 y de 1996 retomó la perspectiva de la televisión como un "servicio público", pero autorizó también el establecimiento de canales de la televisión privada. Para la última, ya no era oportuno el antiguo estatus negativus enfocado en la defensa del particular (empresario) frente a intromisiones, pues el problema político-societal fue mucho más la concentración informativa en poderosos monopolios y oligopolios privados que pusieron en peligro el pluralismo informativo exigido por la carta que es esencial para la sociedad democrática. Efectivamente, la concentración del poder de opinión en pocos miembros de la élite político-económica, posibilitó una nueva forma de compra de votos: la costosa propaganda sistemática y unilateral, difundida visualmente hasta el interior de toda vivienda, sirvió para dirigir los pueblos mayoritariamente pobres y poco educados hacia la aprobación electoral de polí-

\footnotetext{
66 Reporteros sin Fronteras, 2019 World Press Freedom Index, https://rsf.org/en/ranking\# (13.2.2019).

67 Véase p. ej. art. 124 de la CP del Perú de 1979; arts. 20 y 75-77 de la CP de Colombia de 1991; arts. 101 y 108 de la CP de Venezuela de 1999; arts. 106 y ss de la CP de Bolivia de 2009.
} 
ticas autolesionantes en beneficio de los intereses minoritarios del espectro burgués y libero-conservador ${ }^{68}$.

\section{e. El laicismo definitivo}

Además, el constitucionalismo de la sexta ola solucionó definitivamente la cuestión religiosa del largo siglo XIX en el sentido liberal del Estado laico ${ }^{69}$, materializando la larga ola de secularización socio-cultural en curso desde los años 60. Fue llamativo que, en 1993, la Corte Constitucional de Colombia anuló grandes partes del Concordato con la Santa Sede de 1973, postulando ahora de modo inequívoco la prioridad del derecho constitucional por encima del derecho canónico ${ }^{70}$. Solo Argentina y Costa Rica han conservado el catolicismo como religión oficial, aunque sin restringir la libertad individual ${ }^{71}$.

\section{f. Últimas liberaciones}

Con la formación de la mentalidad pos-heroica después de la Segunda Guerra Mundial, los países europeos y americanos se vieron desafiados por la exigencia de reconocer un derecho fundamental de la objeción de conciencia al servicio militar obligatorio. Varios Estados lo resolvieron por la desmilitarización de la sociedad, derogando la conscripción o por lo menos su aplicación, así Costa Rica y Uruguay en 1948, Argentina en 1994, el Perú en 1999 y el Ecuador en 2009, mientras casi todos los otros la redujeron al mínimo. En el último país con conscripción masiva, Colombia, la Corte Constitucional esperó hasta dos sentencias de 2009 y 2013 para tomar en serio el derecho a la objeción de conciencia, constitucionalizado en

68 Comp. Echeverri \& Duque, Política y constitucionalismo, pp. 256 y ss; Mejía et al., Teoría crítica de los medios de comunicación, pp. 74 y ss, 107 y ss, 145 y ss.

69 P. ej. el art. 19 de la CP de Colombia de 1991 y el art. 59 de la CP de Venezuela de 1999.

70 CCC, Sent.C-027/93. Comp. Quinche R., Derecho constitucional colombiano, pp. 156 y ss.

71 Art. 2 de la CP de Argentina de 1994; art. 75 de la CP de Costa Rica de 1949, con la reforma de 2001. 
1991, aunque el interesado todavía necesitó pasar por batallas jurídicas estresantes ${ }^{72}$.

Otra de las últimas liberaciones se refirió a la apertura de la vida matrimonial para parejas del mismo sexo. Típicamente, fue impuesta por la justicia constitucional que anuló las normas contrarias del respectivo Código civil, así en Argentina en 2009, en Brasil en 2013, en México en 2015, en Colombia en 2016, en Costa Rica en 2018 y en el Ecuador en 2019. Se trata de un tema impactante en términos iusteóricos, pues muestra bien la tensión entre un discurso de derechos y el principio democrático. Efectivamente, venció una nueva visión de justicia desde una posición minoritaria que no hubiera podido imponerse según el principio mayoritario -las encuestas calcularon los opositores alrededor de las dos terceras partes de la respectiva sociedad-, mientras resultó invencible desde una reinterpretación como derecho humano y fundamental inalienable. Por su parte, Chile permitió la unión civil en 2015. En cambio, Bolivia, Guatemala, Honduras, Paraguay, Perú y Venezuela se niegan a ambas formas.

\section{g. Violaciones masivas en el último conflicto armado interno}

No es ningún gran secreto que los conflictos armados son tiempos pésimos para los derechos más básicos como a la vida, la integridad física y la libertad en sentido estricto. Solo un país de la zona no logró la salida de la conflictividad político-social de la era del anti-constitucionalismo: Colombia. A primera vista, la Constitución política de 1991 pareció como un símbolo de la vuelta a la paz territorial que quiso hacer todo de modo correcto. Según el concepto del constitucionalismo pluralista, se normativizaron la paz democrática e incluyente, la paz de la dignidad humana, la paz de la justicia social y la paz ambiental, aparte de especificar el derecho y deber a la paz. En contra de la voluntad de la constituyente, debe verse el contexto principal

$72 \mathrm{CDH}$, Informe analítico, p. 17; Quinche, Derecho constitucional colombiano, pp. 167 y ss. 
de la entrada en un camino especial, en la traición de la paz naciente por segmentos significativos de las élites alto-burgueses de corte derechista que vieron en el anticomunismo y la contrainsurgencia las estrategias más prometedoras para salvar su liderazgo tradicional.

Precisamente, el proceso de paz en curso desde 1985, fue saboteado de manera bidimensional, tanto por la excesiva paramilitarización rural que creó monstruosos ejércitos 'privados' para la caza guerrillera -que actuaron según la jurisprudencia consolidada de la Corte Interamericana en Derechos Humanos en plena esfera de responsabilidad del Estado ${ }^{73}$-, como por el politicidio de más de 3.000 miembros y simpatizantes del partido político Unión Patriótica -principalmente compuesto por ex guerrilleros pacificados-, cometido por asesinos 'desconocidos' que velaron bajo la capa protectora de la institucionalidad inactiva ${ }^{74}$, lo que destruyó toda confianza mínima de la guerrilla socialista para una vuelta seria a la mesa de negociaciones durante dos decenios. Mientras la constitución de 1991 promulgó de modo aspiracional el derecho a la paz, las élites ultraderechistas buscaron una 'paz' vencedora a cualquier coste, radicalizando la violencia sistémica a dimensiones monstruosas: ninguna dictadura del Cono sur jamás había sido tan mortal.

El arte de la ingeniería jurídica consistió en crear un ámbito de estado de sitio en un país que había abolido el estado de sitio formal. El trueque decisivo consistió en la evaluación de la actividad militar en el interior a través de las gafas del llamado derecho internacional humanitario, es decir, el ius in bello, que contuvo un estándar protector más flojo que los tres sistemas normativos de los derechos humanos internacionales,

73 Comp. las sent. 19 comerciantes (2004), Mapiripán (2005), Pueblo Bello (2006), Ituango (2006), la Rochela (2007).

74 Corte IDH, Caso M. Cepeda V./UP, de 2010; JEP, Abre el caso 06 UP, de 4.3.2019; Pazos \& Sánchez, Graves violaciones de ddhh, pp. 46 y ss., 64, 137, 180, 274 y ss., 278; CNMH, Todo pasó frente a nuestros ojos, pp. 21 y ss, 105 y ss, 183 y ss; Huertas D., Genocidio y proceso de paz, pp. 168 y ss. 
los derechos fundamentales constitucionalizados y el derecho penal que protegen el derecho a la vida, a diferencia del ius in bello. En momentos en los cuales el Estado negó la existencia del conflicto armado, esto pudo ser radicalizado hacia un bello sine ius. De tal manera, se formaron dos zonas jurídicas más separadas que entrelazadas, con el Estado normativo -de derecho- en los principales altiplanos de la zona andina y en la franja central de la costa Caribe y el Estado de medidas -violentas- en las tierras bajas de clima caliente que fueron poco institucionalizadas y anárquicas, construyendo un muro virtual entre el territorio de la constitución y el otro territorio del flojo ius in bello/bello sine ius que es, efectivamente, ius barbarum.

El caso más emblemático de la barbaria sine ius, es el de los llamados falsos positivos: se refiere a más de 2.000 ejecuciones extralegales cometidas entre 1988 y 2014 por las fuerzas armadas que secuestraron y asesinaron sistemáticamente a jóvenes pobres, los disfrazaron como guerrilleros caídos en combate y recibieron los elogios por su presunta eficiencia militar. En la actualidad, significa un formidable desafío para la rama judicial ${ }^{75}$.

Finalmente, en 2005 el Estado colombiano desarmó 'sus' 32 mil paramilitares y, en 2016, el Estado y la principal guerrilla lograron el Acuerdo final para la terminación del conflicto $y$ la construcción de una paz estable y duradera ${ }^{76}$ que recibió rango constitucional al año entrante. La perspectiva de éxito no es tan negativa, aunque reclama prudencia la tasa muy alta de asesinatos de líderes sociales y ex combatientes en el campo, así como el incumplimiento con la reforma rural acordada. El camino parece todavía largo ${ }^{77}$.

\footnotetext{
75 JEP, Abre el caso 003 'Muertes ilegítimamente presentadas como bajas en combate por agentes del Estado', de 23.7.2018; Corte IDH, Caso Villamizar, de 20.11.2018.

76 Ley colombiana 975 de 2005; Acuerdo final para la terminación del conflicto y la paz estable y duradera de 2016.

77 Sobre conflicto y paz en Colombia en detalle: Marquardt, La paz territorial como paz judicial, pp. 17-104.
} 


\section{c. La profundización de la democracia social}

La sexta ola no solo fortaleció el constitucionalismo liberal, sino consolidó del mismo modo o aun más el constitucionalismo de la democracia social. Independiente de la contrapresión del Consenso de Washington y de la retórica mercado-céntrica intensa de varios partidos políticos, no es posible encontrar una sola constitución latinoamericana de la sexta ola con un perfil puramente 'neoliberal'. La fase más difícil del constitucionalismo social iberoamericano había tenido lugar entre 1949 y los años 80, mientras que la década alrededor de 1990 llevó a una distensión que fortaleció las tendencias originalmente establecidas en la cuarta ola entre 1917 a 1949.

\section{a. Los derechos humanos sociales}

La iusfundamentalización de la responsabilidad social del Estado, fue prevista, conforme con la respectiva propuesta weimariana de 1919, desde cartas zonales como la peruana de 1920, la boliviana de 1938, la cubana de 1940 o la argentina de 1949, así como análogamente al constitucionalismo mundial de las Naciones Unidas de 1966. Por lo tanto, Iberoamérica tendió a entender los principios sociales como verdaderos derechos naturales y universales, por encima del poder dispositivo del Estado, es decir, el poder público puede concretarlos, pero no tiene la soberanía para negarlos o desvalorizarlos. En particular, las constituciones realmente nuevas como la brasileña de 1988, la colombiana de 1991, la paraguayana de 1992, la peruana de 1993, la venezolana de 1999, la ecuatoriana de 2008 o la boliviana de 2009 , fueron muy detallados al respecto, al igual como México lo logró a través de múltiples reformas parciales, especialmente de sus artículos 3 y $4^{78}$.

\footnotetext{
78 Arts. 6-11 de la CP de Brasil de 1988, arts. $42-77$ de la CP de Colombia de 1991; arts. 68100 de la CP de Paraguay de 1992, arts. 4-29 de la CP del Perú de 1993, arts. 75-118 de la CP de Venezuela de 1999, arts. 12-55 de la CP del Ecuador de 2008 ("derechos del buen vivir"), arts. 16-20, 35-97, 104-107 de la CP de Bolivia de 2009. Vid. Arango, El concepto de derechos sociales fundamentales, pp. 31 y ss; Íd., La justiciabilidad de los derechos sociales
} 
Un buen ejemplo del empuje social es la Constitución de Colombia de 1991, la cual consolidó el camino nacional iniciado en la reforma constitucional de 1936 por retomar de la Ley fundamental alemana de 1949 la finalidad de servir como un "Estado social" (de derecho). En particular, estableció un capítulo detallado de 36 artículos sobre "los derechos sociales, económicos y culturales" que, entre otros, incluyeron los siguientes contenidos: "la asistencia de las personas de la tercera edad"; "se garantiz[ó] a todos los habitantes el derecho irrenunciable a la seguridad social" y "el acceso a los servicios de promoción, protección y recuperación de la salud"; "todos los colombianos tienen derecho a una vivienda digna"; se reconoció un extenso catálogo de derechos para los trabajadores; se definió que "la propiedad es una función social que implica obligaciones" y se promulgó que "la educación es un derecho de la persona y un servicio público" con un carácter "obligatorio entre los cinco y 15 años de edad", incluyendo su acceso universal y "gratuito", cuando menos para los pobres. Todo esto requirió de la concreción por normas del derecho administrativo y, aun más, por múltiples sentencias diseñadoras de la Corte Constitucional que tomó los derechos sociales más en serio que los congresistas a menudo incumplidos ${ }^{79}$.

Fueron aun más detalladas e innovadoras las constituciones ecuatoriana de 2008 y boliviana de 2009. Recapitulando los subcapítulos del amplio catálogo boliviano de garantías con un total de 94 artículos, se detectan de modo diferenciado los derechos civiles, políticos, de las naciones indígenas, al ambiente, a la salud y a la seguridad social, al trabajo y al empleo, a la propiedad, de la niñez, de las familias, de las personas adultas mayores, de las personas con discapacidad, de las personas

fundamentales, pp. 20 y ss; Gargarella, Teoría y crítica del derecho constitucional, pp. 318 y Ss, 965 y ss.

79 Arts. 42-77 de la CP de Colombia de 1991. Al respecto: Arango, La justiciabilidad de los derechos sociales fundamentales, pp. 20 y ss.; Romero, Constitucionalismo social en América Latina, pp. 84 y ss; Íd., El péndulo del constitucionalismo social, pp. 277 y ss.; Uprimny, Las transformaciones constitucionales recientes, p. 115. 
privadas de libertad, de los usuarios y consumidores y sobre la educación, cultura e interculturalidad, acompañados por los deberes fundamentales y las garantías jurisdiccionales y acciones de defensa. Este catálogo se despidió claramente del antiguo modelo del siglo XIX de meros derechos que sirvieron para la minoría de los burgueses comerciales y letrados, negando la efímera teoría de la supuesta jerarquía histórica que afirma la primacía de los derechos liberales. En cambio, la carta boliviana pretendió detectar sistemáticamente las necesidades del ser humano en la sociedad industrial moderna, transformándolas en derechos inviolables explícitos con el fin de hacer al ser humano capaz a superar situaciones de vulnerabilidad frente a cualquier privación estatal, privada o estructural. Con un alto grado de diferenciación según contextos y ciclos de la vida moderna, apareció el ciudadano ambiental, el ciudadano social, el ciudadano familiar, el 'ciudadano' menor de edad, el ciudadano anciano, el ciudadano consumidor, el ciudadano indígena, etc. El Estado fue obligado a promover activamente la materialización en beneficio de todos los que pertenecieron a los grupos señalados, especialmente los más vulnerables ${ }^{80}$.

Varios países latinoamericanos ampliaron los derechos sociales por transferir explícitamente dos de las necesidades más básicas de la existencia humana en garantías al nivel constitucional. Uno de estos fue el derecho al agua, a través del cual se elevó un servicio público clásico del derecho administrativo al carácter de derecho fundamental. Por ejemplo, el Uruguay lo constitucionalizó por plebiscito en 2004 -bajo la garantía del monopolio estatal-, seguido por Ecuador en 2008, Bolivia en 2009 y México en 2012. En Colombia, la Corte Constitucional derivó este derecho del deber estatal a prestar los servicios públicos en 2011. Esta ola puede interpretarse como una reacción a diversos excesos y abusos en las reformas 'neoliberales' que privatizaron acueductos municipales, empeoraron la calidad, aumentaron los precios y quitaron el servicio a morosos,

80 En particular, arts. 20 y 13 de la CP de Bolivia de 2009. 
muy visiblemente en el duro conflicto social llamado la guerra del agua de Cochabamba en Bolivia. Por lo tanto, tampoco es ninguna casualidad que se basó en Bolivia la propuesta de reconocer internacionalmente el derecho al agua, lo que las Naciones Unidas formalizaron en $2010^{81}$. El segundo asunto de reforma fue el derecho a la alimentación suficiente, sana y de calidad. Ya la constitución colombiana de 1991 reconoció dicho derecho, pero de modo limitado en el catálogo de los derechos del niño. Fue constitucionalizado sin esta limitación en países como Ecuador en 2008, Bolivia en 2009, Brasil en 2010 o México en $2011^{82}$. Sin embargo, pese a que pocos latinoamericanos mueren de hambre, las Naciones Unidas parten de un nivel de subalimentación significativo: supera el $10 \%$ de la población en Centroamérica, Venezuela, Bolivia y Paraguay y alcanza el 6,5 \% en Colombia, mientras Cuba, Brasil y Uruguay muestran las tasas más bajas de la zona ${ }^{83}$. El problema central se funda en la ausencia de políticas sistemáticas de asistencia social.

Normativamente, el idealismo iberoamericano en los derechos sociales es impresionante y supera a las constituciones europeas -y aun más a la norteamericana socialmente ciega-. No obstante, de esta observación no puede deducirse una mayor calidad del Estado social, pues la materialización depende decisivamente de las respectivas normas del derecho administrativo y tributario -y en cuanto a ambas, América Latina muestra vacíos muy amplios-.

b. La gran tensión: reformas 'neoliberales'versus consolidación de la democracia social

Es preciso advertir que en la misma sexta ola, se dieron dos desarrollos contradictorios: la profundización del iushumanismo

\footnotetext{
81 Art. 47 de la CP del Uruguay de 2004; art. 12 de la CP del Ecuador de 2008; art. 373 de la CP de Bolivia de 2009; Decreto mexicano de 2012; CCC, Sentencia T-740/11.

82 Art. 44 de la CP de Colombia de 1991; art. 13 de la CP del Ecuador de 2008; art. 16 de la CP de Bolivia de 2009; Enmienda brasileña 64 de 2010; Decreto mexicano de 2011.

83 FAO et al., Panorama de la seguridad alimentaria 2018, p. 6
} 
de la democracia social y las reformas estructurales llamadas 'neoliberales'. Al nivel constitucional, la primera se presentó solemnemente en normas centrales, mientras las últimas aparecieron más de modo cifrado y escondido, sin mucho revuelo, casi como algo embarazoso. Esencialmente, el derecho 'neoliberal' fue derecho administrativo, pero de un nuevo tipo que suavizó la frontera hacia el derecho civil. En su núcleo, tendió a un Estado delegatorio que usó sujetos del derecho civil como prestadores de lo público a través de concesiones, obligándolos mediante deberes legislados y contratos públicos-privados, lo que la voz popular denominó 'privatizaciones'. Principalmente, el neoconcesionismo afectó al seguro social y los servicios públicos.

Este no es lugar para discutir todos los contextos e implicaciones del paradigma 'neoliberal', pero cabe destacar que el modelo fue impuesto por las lejanas potencias del núcleo industrial, a través de la palanca de las instituciones financieras con sede en Washington, tanto por convicciones ideológicas de corte mercado-centrismo como por intereses duros de un ecoimperialismo que buscó consolidar las enormes huellas ecológicas de estas potencias mediante estrategias económicas que aseguraron un permanente metabolismo agro-minero a gran escala en beneficio del hedonismo de ellos. Por otra parte, se beneficiaron las élites locales que recibieron, por precios cómodos, los cubiertos de plata del Estado con las respectivas opciones atractivas de acumular ganancias. De todos modos, al neo-concesionismo fue inherente una tendencia a la ineficiencia, tanto por los intereses unilaterales de los prestadores privados hacia segmentos lucrativos de la sociedad como por la finalidad adicional de lo público que sirvió ahora, también, para financiar las enormes expectativas de ganancias de los accionistas y los salarios muy altos de los gerentes top; además, en situaciones de crisis los privados tendieron a escaparse hacia la bancarrota, dejando el manejo del respectivo escenario desolado para la garantía general del poder público.

En cuanto a las 'privatizaciones', pueden distinguirse tres tipos de países iberoamericanos: los que lo hicieron muy 
ampliamente, los que resistieron y los que revocaron total o parcialmente un intento inicial debido a malas experiencias. Con respecto a las pensiones, la ola privatizante despegó en la dictadura chilena en 1980, difundiéndose al Perú y Colombia en 1993, a Argentina en 1994, a Bolivia y Uruguay en 1996, a México en 1997 y a El Salvador en 1998. En cambio, Brasil, Costa Rica, Guatemala y Venezuela prolongaron el modelo público en manos del respectivo instituto nacional. Al estilo de un tercer camino, Uruguay permitió un modelo mixto bajo la supervivencia paralela de un pilar estatal con el derecho del ciudadano a elegir. En cuanto a la esfera del seguro de salud, Colombia lo entregó a prestadores privados mediante la legislación de 1993, pero continuó prevaleciendo el modelo público en Brasil, Chile, Costa Rica, Guatemala, México y Venezuela. Debido a experiencias dolorosas, especialmente Argentina y Bolivia tendieron a la recuperación del manejo público directo en la primera década del siglo $\mathrm{XXI}^{84}$.

Entre las materias más controvertidas de las reformas 'neoliberales', destaca el derecho laboral. Mientras las constituciones promulgaron solemnemente la sociedad laboral justa, en realidad se difundió una ola de desprotección con patrones neo-explotadores como contratos a término fijo, la intermediación laboral por servicios temporales o la circunnavegación del derecho laboral por contratos unilateralmente civiles como los de prestación de servicios ${ }^{85}$.

En síntesis, la democracia social constitucionalizada en todo el continente, fue desafiado por la puerta trasera, a través de un paquete de reformas anarco-liberales que rindieron homenaje a un modelo diferente que puede denominarse econocracia -el dominio de las élites económicas-. Mientras la democracia social se fundamenta en un iushumanismo, el neoliberalismo representa un anti-iushumanismo, lo que el constitucionalista

84 Cfr. Castro, Salud y seguridad social, pp. 7 y s; OCDE et al., Panorama de las pensiones, pp. 50 y ss, 71 y ss.

85 Vid. Vega, La reforma laboral en América Latina, pp. 11 y ss, 34 y ss 
Llinás ha calificado como la promoción de un "Derecho público multinacional y anti-constitucional" ${ }^{\prime 66}$.

\section{c. El constitucionalismo pedagógico y el derecho a la educación}

Entre otros aspectos, el constitucionalismo social de la sexta ola de dedicó detalladamente a la educación, formulada, por ejemplo, en la Constitución de Colombia de 1991 como "un derecho de la persona y un servicio público que tiene una función social", junto con el deber "que será obligatoria" hasta la edad de 15 años, bajo la enunciación de una variedad de fines pedagógicos orientados al bien común: "En todas las instituciones de educación [...] será obligatorio el estudio de la Constitución [...]. La educación formará [...] en el respeto a los derechos humanos, a la paz y a la democracia; y [...] para el mejoramiento cultural, científico, tecnológico y para la protección del ambiente" ${ }^{87}$. La materia como tal no era tan novedosa, teniendo en cuenta, para corregir la extendida hipótesis de la ceguera social del constitucionalismo liberal del siglo XIX, que este mismo había incluido desde sus inicios un fin social particular: la educación pública, pues ya la constitución materna del republicanismo hispanoamericana, la de la República de Tunja de 1811, había previsto escuelas "en todos los pueblos" según el ideal de igualdad sin "preferencias ni distinciones, entre blancos, indios, u otra clase de gente" 88 .

No obstante, estas aspiraciones solemnes son contrarrestadas por una variedad de problemas estructurales: primero, llama la atención el camino especial latinoamericano del amplio grado de privatización de la educación que lleva a un régimen de apartheid educativo sin igualdad de oportunidades, con excelentes y costosos colegios privados para la élite y mediocres colegios públicos para los demás. Segundo, los informes

\footnotetext{
86 Llinás, ¿Derecho público multinacional y anti-constitucional? pp. 185-264.

87 Arts. 67 y 41 de la CP de Colombia de 1991.

${ }^{88}$ Cit. por Marquardt, Historia constitucional comparada de Iberoamérica, p. 81.
} 
PISA de la OCDE, realizados con frecuencia desde 2000 para medir el rendimiento de estudiantes de 15 años de edad, exponen en serie los países participantes de América Latina -entre ellos, Argentina, Chile, Colombia, México y Perú- entre los colistas con los peores logros educativos. Tercero, también en la educación universitaria se repite un amplio nivel de privatización, aunque en este caso sin el efecto de la mediocridad de lo público sino que, al revés, muchas privadas son meras universidades de garaje que venden títulos; en Chile la universidad privada ganó la mayoría de los estudiantes a partir de 1990 y, finalmente, una cuota por encima del $70 \%$, mientras Colombia cuenta con una relación casi mitad-mitad entre lo público y lo privado, a diferencia de México donde el segmento privado nunca superó la tercera parte y en Argentina el mismo quedó por debajo de la cuarta parte; para comparar: en un país del núcleo industrial como Alemania, el $95 \%$ de los estudiantes está matriculado en una universidad pública. Cuarto, algunos países de la zona muestran un pésimo empeño en el nivel top de la formación universitaria, pues Chile produce solamente 0,7 mil nuevos doctorados al año y Colombia 0,8 mil, mientras Argentina alcanza por lo menos 2,3 mil, México notables 9,3 mil y Brasil incluso 21,6 mil, lo que puede comparase con los 28,4 mil en Alemania. Quinto, de acuerdo con el punto anterior, solo el $7 \%$ de los profesores universitarios de Colombia cuenta con el título de doctorado y en Chile el $19 \%$, es decir, la gran mayoría no está calificada para su profesión según estándares internacionales ${ }^{89}$.

En efecto, varios países de la zona solo promueven el $20 \%$ de las capacidades de sus estudiantes y se contentan con un personal dirigente en Estado y economía de calificación subóptima. Puede concluirse que la realidad no cumple con las promesas constitucionales: ni en cuanto a la calidad ni con

89 García \& Quiroz, Apartheid educativo, pp. 137-162; OECD, PISA 2018 Results, What Students know, pp. 17-18; OECD, Education at a Glance 2019, p. 257; Duque et al., Bases del Plan Nacional de Desarrollo, p. 546; Díaz L. et al., Formación docente en Chile, p. 233. 
respecto a la ficción de la educación como un valioso bien público.

d. El vacio sistémico y su efecto: la ausencia del aseguramiento básico y el proletariado informal

La Corte Constitucional de Colombia adoptó en varias sentencias a partir de 1992, análogamente a la tradición jurisprudencial alemana desde 1954, el derecho al mínimo vital como concreción de la dignidad humana. Sin embargo, los jueces bogotanos circunnavegaron el paso a llenar esta aparente promesa con el mismo contenido, pues limitaron el alcance esencialmente a calificar los ingresos básicos en relaciones laborales y pensionales establecidas en vez de obligar al Estado a materializar activamente la dignidad de los más vulnerables afuera de estas relaciones. Pese a toda retórica benevolente, no fueron dispuestos a reconocer la obligación pública a la asistencia social sistemática ${ }^{90}$.

De tal manera, se visibiliza la diferencia principal entre el Estado social europeo y su homólogo latinoamericano: los europeos reconocen la financiación pública subsidiaria pero sistemática y, en caso necesario, duradera de los costos mensuales de la vida digna de personas sin capacidad a sostenerse por ingresos de tipo mercado laboral o pensión, mientras los latinoamericanos se niegan a esta idea costosa y se contentan, en el mejor de los casos, con algunos programas ad boc de alcance temporal, personal y/o zonal limitado sin verdadera institucionalización administrativa. Lo que en perspectiva europea es el elemento constitutivo y nuclear del Estado social solidario, queda ausente en Iberoamérica.

Como una excepción del estilo ad hoc, figuraron las pensiones asistenciales no contributivas. Esta atención básica para todo anciano pobre se estableció en Argentina, Brasil, Chile, Cuba, Uruguay, Venezuela y, pese a su condición como uno de

90 CCC, T-426/92 y T-015/95. También: SU-995/99, T-581 a/11, T-678/17 y T-716/17. 
los países más pobres de la zona, Bolivia a través de su pensión universal de vejez, introducida en $2010^{91}$.

De todas maneras, mientras la asistencia social europea desconstruyó los barrios miserables de la primera fase industrial -omnipresentes alrededor de 1900- y evitó el establecimiento de un proletariado informal, el vacío latinoamericano promovió la formación de slums -omnipresentes alrededor de 2020- y damnificó enormes partes de la sociedad a la informalidad precaria. Las dimensiones cuantitativas no son de fácil acceso, pues el tema es delicado para los respectivos países, pero el promedio continental de la población urbana slumificada oscila entre la cuarta y la tercera parte y la tasa de informalidad incluye aproximadamente la mitad de la población ${ }^{92}$. Esta población de los nuevos barrios marginales urbanos de la segunda mitad del siglo XX e inicios del XXI, se ubica afuera de casi toda solidaridad republicana, con efectos secundarios como una enorme tasa de criminalidad.

\section{e. La defensa judicial de los derechos sociales}

Típicamente, las constituciones iberoamericanas de la sexta ola siguieron la propuesta de la carta cubana de 1940 y configuraron las garantías sociales en la esfera de lo exequible a través de los jueces. Varias cartas se abrieron explícitamente a este logro como la peruana de 1993, la argentina de 1994, la venezolana de 1999, la ecuatoriana de 2008 o la boliviana de 2009, a diferencia de Chile con su constitución de inspiración en el 'neoliberalismo' pinochestista y México con su larga tradición del amparo liberal. La Corte Constitucional de Colombia partió inicialmente de una compleja jerarquización de los derechos, bajo la prioridad de los liberales y la necesidad de

91 Bosch et al., Mejores pensiones, mejores trabajos, pp. 36 y ss; Rojas Y., Sistema de pensiones/ Bolivia, pp. 221-241.

92 Salazar \& Chacaltana, Políticas de formalización, pp. 18 y ss; UN-Habitat, Slums of the World, p. 79. 
interpretaciones particulares para los demás según el carácter del respectivo derecho, pero efectivamente aplicó estas interpretaciones crecientemente de modo pro-social ${ }^{93}$.

No obstante, como una herencia de la ideologización anticomunista en la Guerra Fría (1946-1989), perduró una cierta oposición frente a la justiciabilidad de los derechos sociales. Sin embargo, fue cada vez menos plausible la afirmada prioridad natural de las libertades burgueses de prensa o de debate frente a necesidades básicas del ser humano como la alimentación y la vivienda. Tampoco resultó contundente la supuesta falta de precisión, pues todo derecho constitucional se formula de modo abstracto. De igual forma, contuvo sus dificultades el argumento del carácter antisistémico del estatus positivus con presión presupuestal, pues también garantías procesales del liberalismo clásico como el debido proceso requieren de la respectiva inversión estatal en el servicio de justicia. Irritó que la oposición esbozara el escenario de una desdemocratización por el recorte de las facultades tributarias del parlamento democrático, donde este mismo abusó de la predominancia de sus miembros burgueses para imponer privilegios tributarios en contra de la mayoría del pueblo. Convenció menos la afirmada incompatibilidad con la economía capitalista, donde esta última se transformó cada vez más en una economía social de mercado. Del mismo modo, es deshonesto negar la manejabilidad por parte de los jueces, si por ejemplo las cortes de la especializada jurisdicción social de Alemania, fundada en 1953,

\footnotetext{
93 Art. 200 de la CP del Perú de 1993, art. 43 de la CP de Argentina de 1994, art. 27 CP de Venezuela de 1999, art. 11 III de la CP del Ecuador de 2008, art. 109 de la CP de Bolivia de 2009. Comp. Arango, La justiciabilidad, pp. 20 y ss; Arenas, De la participación ciudadana, pp. 149 y s; Ferreyra, Notas sobre derecho constitucional y garantías, pp. 438 y ss; Gargarella, Teoría y crítica del derecho constitucional, pp. 318 y ss, 965 y ss, 973 y ss; Landau, Los derechos socioeconómicos sin transformación social, pp. 265-304; Llinás, Los derechos sociales, pp. 508 y ss; López, Constitucionalización y protección judicial, pp. 27-41; Íd., La justicia constitucional colombiana, pp. 249 y s; Quinche, Derecho constitucional colombiano, pp. 316 y ss; Romero, Derecho fundamental a la salud, pp. 27 y ss, 37 y ss, 55 y ss; Saffon \& García, Derechos sociales y activismo judicial, pp. 75-107; Uprimny, La judicialización de la política, pp. 51 y s; Íd., The Enforcement of Social Rights, pp. 132 y ss.
} 
han logrado trabajar de modo estandarizado sobre disputas del derecho social.

En términos precisos, la Defensoría del Pueblo colombiano presenta cifras según las cuales casi las dos terceras partes de las acciones de tutela solicitan la protección de derechos sociales como la salud, el mínimo vital, la ayuda humanitaria, la seguridad social, la educación o la vivienda digna, lo que subraya la necesidad de la justiciabilidad, provocada por el pésimo empeño de la administración social semi-privatizada. En la Colombia de 2018, se contó un total de 607.308 acciones de tutela, de éstas el 34,21 \% relacionado con la salud, primordialmente solicitando tratamientos, el acceso a medicamentos, citas médicas rechazadas o cirugías negadas. En general, la cifra alta del 59,11\% de los fallos de primera instancia favoreció a los ciudadanos y, en materia de salud, incluso el 82,2 \%. Es una nota de vergüenza para las privatizadas entidades promotoras de salud que quieren beneficiarse del subcumplimiento sistemático. Sin cambio del diseño básico del régimen de salud, el control judicial constante parece inexorable ${ }^{94}$.

No es falso afirmar que, en perspectiva mundial, la Corte Constitucional de Colombia asumió un papel de liderazgo en la defensa judicial de los derechos fundamentales de tipo social. A partir de 1992, trabajó creativamente en el diseño y la operabilidad de los mismos. Los magistrados precisaron el significado del Estado social de Derecho (1992, 1995, 2008), el mínimo vital (1992, 1995, 2011) y los derechos del indigente (1992). De modo exigente, se dedicaron al derecho a la seguridad social (2006, 2008), a las pensiones (2011), al derecho a la salud (2008, 2014), al derecho a la educación (2000), al derecho a la vivienda digna (desde 2007) y al principio de la progresividad y probibición de regresividad de los derechos sociales (2011). En cuanto a la salud, señalaron en la sentencia clave de 2008: "El derecho a la salud es un derecho constitucional fundamental. [...] Toda

94 Defensoría del Pueblo, La tutela 2018, pp. 51, 53, 60 y ss. 
persona tiene el derecho de pertenecer al Sistema de Salud. [...] El derecho fundamental a la salud, comprende, entre otros, el derecho a acceder a servicios de salud de manera oportuna, eficaz y con calidad [... C] ]omprende el derecho a acceder a los servicios de salud que se requieran con necesidad". Dicha sentencia llevó, en 2015, a la Ley estatutaria por medio de la cual se regula el derecho fundamental a la salud. De tal manera, la Corte promovió transformaciones sociales en el espíritu de los derechos humanos, trabajando constructivamente en la superación de las resistencias y lentitudes de la política parlamentaria. En el contexto colombiano, la Corte Constitucional tiene que defender los valores sociales tanto contra gobiernos liberoconservadores que no los estiman profundamente, como contra el escapismo notorio de los prestadores privados en deberes públicos delegados que no son tan lucrativos. Frente al negacionismo fiscal del gobierno, en 2014, los jueces subrayaron que el Estado dispone de recursos suficientes y argumentaron que la llamada "sostenibilidad financiera no puede comprender la negación a prestar eficiente y oportunamente todos los servicios de salud debidos a cualquier usuario" incluyendo el pobre sin capacidad de pago ${ }^{95}$.

f. Sin impuestos progresivos sobre la renta no hay democracia social

Entre las excusas de las bajas prestaciones del Estado social iberoamericano a los pobres, destacan imaginarios de supuestos países pobres sin suficientes precondiciones de desarrollo. Esto parece sumamente irritante para países que, en el mundo del presente, pertenecen a un nivel relativamente elevado de desarrollo y que disponen de mucha riqueza interna. El punto no es no tenerla, sino no usarla. En realidad, el problema más profundo de la estatalidad social iberoamericana, radica en la

95 CCC, T-406/92; C-566/95; C-336/08; T-426/92; T-015/95; T-581a/11; T-533/92; C-111/06; T-701/08; T-716/11; T-760/08; T-202/00; T-1017/07; C-444/09; T-530/11; C-228/11; C-313/14; Ley estatutaria 1.751 de 2015. 
subfinanciación notoria por un sistema tributario premoderno que rechaza una suficiente redistribución de la riqueza interna en beneficio del bien común. En contraste con las transformaciones sociales del derecho tributario en los Estados del núcleo industrial desde la Primera Guerra Mundial, muchos países de América Latina defendieron enérgicamente la casi libertad tributaria de la élite político-económica, inversa al modelo estándar de los impuestos progresivos sobre la renta -que solo es previsto semánticamente en normas locales como el artículo 363 de la Constitución de Colombia de 1991-. En efecto, en 2019, la cuota de contribuciones (impuestos y otras cargas sociales), medida como porcentaje del Producto Interno Bruto, alcanza solamente en tres países de América Latina una dimensión casi sólida -el 32,2 \% en Brasil, el 30,8 \% en Argentina y el 27,4 \% en Uruguay-, mientras que se presenta todavía muy baja en Chile con el 20,4\%, en Colombia con el 19,9\%, en México con el 17,2 \%, en el Perú con el $16 \%$ y en Guatemala con el 12,6 \%, lo que puede contrastarse con las cifras de los países exitosos del núcleo industrial -señalando el 45,9\% en Dinamarca o el $45,3 \%$ en Francia- ${ }^{96}$. El problema no radica en la frecuentemente citada corrupción individual, pues el diseño sistémico mismo entrega privilegios tributarios anacrónicos.

\section{g. Observaciones conclusivas}

En términos comparativos, existen datos económicos que encarnan prácticamente notas de la calidad material de la estatalidad social. La medida más aceptada es el coeficiente de Gini, empleado por el Banco Mundial y las Naciones Unidas, que señala la igualdad o desigualdad de los ingresos en un cierto país. Desde los años 90, expone permanentemente a América Latina como la zona más desigual de todo el planeta. Dentro de esta plusmarca mundial, los países con la mayor polarización son Brasil, Colombia, Panamá, Honduras, Costa Rica, Guatemala,

96 Heritage Foundation, 2019 Index of Economic Freedom. 
Paraguay y Chile -equivalentes a la nota muy deficiente-, mientras como los más moderados aparecen México, Argentina y el Uruguay -equivalentes a la nota deficiente-, en lo que se ubican todavía muy lejos de los valores nor y centroeuropeos -equivalente a la nota suficiente-. También llama la atención que por lo menos dos países de la zona mejoraron significativamente desde los años 90: Bolivia y Nicaragua ${ }^{97}$.

Complementariamente, es explicativo mirar a los ingresos muy altos, pues las reformas 'neoliberales' tenían el efecto que crecieron más rápidamente que todos los demás. Precisamente, se señala que en Brasil y Chile la parte del $10 \%$ más rico de la población en los ingresos nacionales es del $55 \%$, a diferencia del $27-35 \%$ en Europa occidental. Además, el 1 \% más rico de los brasileños se reserva en sus manos el 28,3\% de los ingresos nacionales, el de los chilenos el $23,4 \%$ y el de los colombianos el 20,4 \%, mientras el $1 \%$ superior de los franceses se apropia 'solamente' del 10,8 $\%{ }^{98}$.

\section{d. La tercera dimensión del triángulo de valores: el ascenso del Estado constitucional ecológico}

Una de las tendencias clave del ECDSA de la sexta ola fue la constitucionalización de la revolución ecológica que había empezado en los años 70 del siglo XX. La precondición más básica del desarrollo del derecho de la protección ambiental, radicó en la formación comunicativa de una conciencia colectiva por el haber entrado en un problema existencial de la humanidad, reconociendo la necesidad de proteger las bases naturales de la vida frente a los riesgos establecidos por el sistema de energía fósil y el metabolismo acelerado de las sociedades de la transformación industrial. No se trató de decisiones aisladas

\footnotetext{
97 PNUD, Índices e indicadores de desarrollo humano, 2018, pp. 30 y ss.

98 Cifras según World Inequality Database, Top 10 \% National Income Share, Íd., Top 1 \% National Income Share. Comp. Alvaredo et al., World Inequality Report 2018, pp. 9, 101, 103 , 139-140.
} 
de países particulares, sino de una ola transnacional al nivel mundial -aunque en intensidades variadas-.

\section{a. La ecologización normativa}

Inicialmente, el derecho ambiental pareció como una de las ramas especializadas del derecho administrativo, manifestándose en normas con tal dedicación como la mexicana de 1971, la colombiana de 1974 o las ecuatoriana y venezolana de 1976. Paralelamente, América Latina empezó a incluir el ambientalismo en su sistema de valores fundamentales del derecho constitucional. Como el precursor zonal se comprobó México en 1971, con una mención muy breve que representó, junto con la reforma suiza del mismo año, la constitucionalización pionera a nivel mundial. Resultó más exigente la Constitución política del aprismo peruano de 1979 que previó un derecho y deber fundamental con respecto al "ambiente saludable, ecológicamente equilibrado". No obstante, la gran ola se dio en el marco de la reconstitucionalización pluralista a partir de la carta de Guatemala de 1985, incluyendo las nuevas normas supremas o reformas de Nicaragua de 1987, de Brasil de 1988, de Colombia de 1991, de Paraguay de 1992, de Argentina y Costa Rica de 1994, de Uruguay de 1996 o de Venezuela de $1999^{99}$.

Como la primera manifestación del constitucionalismo ecológico de la década de 1990, puede reconocerse la exigente Constitución de Colombia de 1991 que normativizó, con mucha atención a los detalles, casi todo elemento discutido en las ciencias jurídicos-ambientales alrededor de 1990: un fin y deber estatal de proteger, un derecho fundamental ambiental del ciudadano, un deber ambiental de los particulares de no sobreexplotar, la redefinición de la propiedad con función

\footnotetext{
99 Reforma const. mexicana de 1971; art. 123 de la CP del Perú de 1979; art. 19 nº 8 de la CP de Chile de 1980; art. 97 de la CP de Guatemala de 1985; art. 60 de la CP de Nicaragua de 1987; arts. 8 et al. de la CP de Colombia de 1991; art. 7 de la CP del Paraguay de 1992; art. 41 de la CP de Argentina de 1994; art. 50 de la CP de Costa Rica (reforma de 1994); art. 47 de la CP del Uruguay (reforma de 1996); art. 127 de la CP de Venezuela de 1999.
} 
ambiental al lado de la limitación social, la economía ambiental, un objetivo educativo en lo ambiental, el lema de la sostenibilidad, así como proporcionando las acciones populares para defender el ambiente y la tutela en torno al derecho ambien$\mathrm{tal}^{100}$. De manera semejante, puede considerarse innovadora la Constitución de Venezuela de 1999 que señaló la combinación entre derecho y deber ambiental, la justicia intergeneracional, el fin estatal y los medios ambientales particulares que deberían ser protegidos. Tanto el texto colombiano como el venezolano superaron en su idealismo y precisión a la reforma alemana de 1994 y la carta suiza de $1999^{101}$. Mediante la inclusión en la categoría de los derechos fundamentales, ambas constituyentes reconocieron del rango iusnatural de lo ecológico ${ }^{102}$.

Paralelamente, surgieron teorizaciones que propusieron términos conceptuales como el Estado constitucional ecológico o el Estado ambiental de derecho ${ }^{103}$. El autor del presente texto propuso originalmente, en 2003, el primer concepto señalado, pero prefiere en el presente el enfoque en el pluralismo tridimensional como el Estado constitucional democrático, social y ambiental $^{104}$.

Dos constituciones de la primera década del siglo XXI perfeccionaron la co-identidad ambiental del Estado constitucional. La primera de estas fue la Constitución del Ecuador de 2008 que "reconoc[ió] el derecho de la población a vivir en un ambiente sano y ecológicamente equilibrado, que garantice la sostenibilidad y el buen vivir, sumak kawsay [... y] declar[ó] de interés público la preservación del ambiente, la conservación

\footnotetext{
${ }^{100}$ Arts. 8, 49, 58, 63, 67, 79-80, 88, 96, 267-268, 277, 300, 333-334 y 366 de la CP de Colombia de 1991.

101 Art. 127 de la CP de Venezuela de 1999.

102 En Colombia aclarado por CCC, Sent. T-536/92.

${ }^{103}$ Comp. p. ej. Montoro, El Estado ambiental de derecho, pp. 3437-3466; Mesa, Derechos ambientales en perspectiva de integralidad, pp. 363 y ss.

104 Marquardt, Teoría integral del Estado ll, título y pp. 273 y ss, 437 y s, 500 y ss.
} 
de los ecosistemas, la biodiversidad y la integridad del patrimonio genético del país, la prevención del daño ambiental y la recuperación de los espacios naturales degradados”. La otra fue la Constitución de Bolivia de 2009 con disposiciones muy detalladas en por lo menos 27 artículos que significan, en su conjunto, uno de los manifiestos verdes más ambiciosos que existen en el mundo contemporáneo, pues se dedicó a todas las dimensiones de la cuestión ecológica y sostenibilidad ambiental, incluyendo la justicia inter-generacional e internacional ${ }^{105}$. No obstante, tampoco debe desconocerse que la carta boliviana contiene, paralelamente al enfoque ambiental, diversas normas acentuadamente desarrollistas que permiten ponderaciones en beneficio de la degradante agricultura y minería industrial.

Cabe destacar que la Constitución del Ecuador de 2008 exhibió un elemento adicional, pues el capítulo dedicado a los "derechos de la naturaleza", complementó la perspectiva antropocéntrica con una connotación biocéntrica. Se definió la naturaleza como un sujeto jurídico "donde se reproduce y realiza la vida", con derechos propios como el de recibir el respeto adecuado para la "regeneración de sus ciclos vitales, estructura, funciones y procesos evolutivos" ${ }^{106}$. Más tarde, Colombia adoptó el mismo enfoque a través de una sentencia de la Corte Constitucional de 2016 que reconoció los derechos propios de la naturaleza en pro del río Atrato, lo que de la Corte Suprema aplicó en 2018 a favor de la selva Amazónica. En la primera de estas, los jueces "part[ieron] de una premisa básica según la cual la tierra no pertenece al hombre y, por el contrario, asum[ieron] que el hombre es quien pertenece a la tierra, como cualquier otra especie"107.

\footnotetext{
${ }^{105}$ Art. 14 de la CP del Ecuador de 2008; arts. 9, 33, 80, 108, 135, 255, 298, 312, 316, 319, 337, 342, 344-347, 349, 357, 379-381, 385, 387, 389-391 y 402 de la CP de Bolivia de 2009.

${ }^{106}$ Cfr. Acosta, Derechos de la naturaleza y buen vivir, pp. 21-28; Gudynas, Politische Ökologie, pp. 215 y ss; Ortega, Constitucionalismo ambiental y derechos ambientales, p. 63; Vargas, El derecho al medio ambiente, pp. 257 y ss.

107 CCC, Sent. T-622/16.
} 
Además, la carta ecuatoriana de 2008 postuló una conexión entre el derecho ambiental y la antigua deidad incaica de Pachamama como Madre Tierra. Esto puede entenderse como una propuesta de establecer una propia legitimidad americana más allá de las figuras del derecho euro-occidental, pero desvía del carácter eminentemente occidental de la revolución ecológica que es eventualmente antiliberal, pero de ningún modo antieuropea. Adicionalmente, puede ser interpretado como un romanticismo indigenista (también el romanticismo viene del siglo XIX europeo) que se aleja de los problemas duros de la reforma ambiental en las mega-ciudades modernas y sus enormes huellas ecológicas.

\section{b. ¿Derechos o deberes ambientales?}

Mientras diversas constituciones europeas como las de Alemania, Suiza o Polonia diseñan el constitucionalismo ecológico a través de fines estatales de la protección ambiental, predomina en América Latina el anclaje en los derechos fundamentales, con excepción de la reforma constitucional uruguaya de 1996 que formuló un fin estatal y deber fundamental ${ }^{108}$. El estilo iusfundamental, defendido en la influyente teoría integral de Mesa ${ }^{109}$, coincide con el derecho-centrismo que es propio a los dos siglos del constitucionalismo hispanoamericano, pero debe ser claro que se extiende una figura de origen liberal a un concepto dedicado a la superación de los excesos de libertad de los particulares -sean personas naturales o jurídicas-. Mejor dicho, la perspectiva del derecho fundamental entra en peligro de ocultar que la idea clave del derecho ambiental no es autorizar nuevas esferas de actuación, sino que consiste mucho más en limitar la destrucción de los sistemas naturales por las diferentes formas del uso humano. No hay duda seria de que los métodos básicos del derecho administrativo ambiental consisten en prohibir,

\footnotetext{
${ }^{108}$ Art. 47 de la CP del Uruguay (reforma de 1996).

${ }^{109}$ Cfr. Mesa, Derechos ambientales en perspectiva de integralidad, pp. 41 y ss, 91 y ss.
} 
establecer límites, obligar a filtrar o no usar y castigar en caso del no respeto.

No obstante, el enfoque hispanoamericano en los derechos ambientales encuentra su justificación en el amplio nivel de desconfianza frente a los poderes legislativos 'econocráticos' de una zona del mundo en la cual los Congresos no se componen tanto de políticos profesionales bien educados, sino mucho más de miembros de la élite económica con intereses propios de lucro y explotación. En un ámbito con estas características, es plausible hacer del ciudadano el guardián del ambiente en vez de esperar que congresistas no tan interesados cumplan con su deber legislativo.

En particular, el constructo del derecho fundamental ambiental facilita y agiliza la justiciabilidad, haciendo de los jueces los defensores del ambiente, teniendo en cuenta su mayor confiabilidad en comparación con los congresistas. Cabe precisar que el carácter básico es aquel de un derecho colectivo, con contenidos no menores a un fin estatal, pero a diferencia de este, también es exigible por el ciudadano consciente a través de los jueces, y no solo por el individuo inmediatamente afectado en sus derechos subjetivos como vecino.

De todos modos, no deben subestimarse las tensiones entre los derechos ambientales y los derechos liberales y sociales: las máximas eco-jurídicas no solo afectan posiciones liberales como la propiedad o libertad de industria, sino también sueños sociales como el American Way of Life para todos. No se trata de tres manifestaciones de lo mismo, sino que entran con frecuencia en contradicciones que deben ser ponderadas responsablemente. En ello, es cierto que el Estado constitucional democrático, social y ambiental transforma definitivamente el Estado de derechos subjetivos de defensa del liberalismo histórico en un modelo mixto con un Estado de deberes que se dedica al deber global de no exceder la huella ecológica planetaria, nacional e individual. En este sentido, el triángulo de valores liberales, sociales y ambientales contiene una jerarquía natural, pues todo realismo según las ciencias naturales obliga 
a reconocer un derecho natural per se que limita tanto las libertades individuales como las garantías sociales a decisiones dentro del espectro de la previsión y precaución ambiental que tiene que orientarse en las capacidades inherentes al único planeta disponible para la existencia de la humanidad.

\section{c. La justicia constitucional y administrativa en asuntos ambientales}

Desde los años 90, el constitucionalismo ecológico se reflejó también en una gran variedad de sentencias de la justicia constitucional, por ejemplo, en Colombia, donde la Corte Constitucional defendía, en el año 1992, los derechos ambientales de los vecinos del Rioseco cundinamarqués contra la contaminación del agua, de origen empresarial y, en el mismo año, a la población de la península de La Guajira frente a los excesos de la industria minera del carbón. En 2010, la misma Corte precisó el carácter de una constitución ecológica que obliga a la actuación preventiva del Estado, cuando los magistrados salvaguardaron la potestad sancionadora de la administración pública. Se añadió, en 2016, el ya citado reconocimiento de los derechos propios de la naturaleza en pro del río Atrato en la selva Pacífica, amenazado por la inactividad de las autoridades frente a la minería ilegal ${ }^{110}$.

De igual forma, el Tribunal Administrativo de Cundinamarca respondió, en 2004, a una acción popular y defendió los derechos colectivos de los cundinamarqueses contra la extrema contaminación del río Bogotá, asociada tanto con el estilo inactivo y permisivo de la administración pública como con las resistencias colectivas frente a la depuración. Los jueces ordenaron el saneamiento del río, lo que el Consejo de Estado tuvo que confirmar en 2014, debido al alto nivel de incumplimiento. Puede verse comparable la sentencia de la Corte Suprema de

${ }^{110}$ CCC, Sent. T-536/92; CCC, Sent. T-528/92; CCC, Sent. Sentencia C-703/10; CCC, Sent. T-622/16. Véase Romero, El principio del desarrollo sostenible, pp. 398 y ss. 
Argentina que ordenó, en 2008, el saneamiento del río MatanzaRiachuelo en Buenos Aires ${ }^{111}$.

También en otras repúblicas latinoamericanas, las cortes de justicia empezaron a defender los derechos ambientales de sus ciudadanos. Por ejemplo, en 2006, el Tribunal Constitucional de Perú juzgó en el caso del pueblo minero y metalúrgico de La Oroya en un valle alto-andino, considerado uno de los lugares más contaminados del mundo -de modo tridimensional del suelo, aire y agua-, a favor de la salud de la población local, obligando a la administración pública a tomar medidas urgentes para proteger a los afectados del envenenamiento permanente con plomo, arsénico, mercurio, material particulado, dióxido de azufre, etc., por parte del propietario estadounidense de la planta metalúrgica privatizada desde 1997. Sin embargo, en vez de invertir para cumplir con los estándares ambientales, la empresa transnacional se declaró en insolvencia en 2009 y la empresa liquidadora motivó a los obreros a ponerse en una serie de huelgas, en pro de su propia intoxicación permanente, según el lema: mejor morir de la contaminación en vez de sufrir de hambre. Para inicios de 2020, está en proceso la transferencia a los trabajadores que pretenden reactivar la planta. Es un buen ejemplo que subraya las posibles tensiones entre fines sociales y ambientales ${ }^{112}$.

\section{d. Aterrizando en la tierra: la eficacia limitada} del constitucionalismo ecológico

Según el idealismo de los textos constitucionales, uno podría esperar que América Latina fuera un paraíso del derecho ambiental, pero la realidad es otra. La calidad protectora no depende tanto del idealismo constitucional, sino mucho más

\footnotetext{
${ }^{111}$ CE, SCA I, exp. AP-25000-23-27-000-2001-90479-01, sent. de 28.3.2014. Vid. Delgado, Políticas públicas, juez constitucional y derechos sociales, pp. 179-203.

112 TCP, exp. 2002-2006-PC/TC, de 12.5.2006. Véase Meza, Judicial Enforcement and the Protection of the Right to Health and the Environment, pp. 169-184.
} 
del diseño y eficacia del derecho administrativo ambiental con sus procedimientos de autorización, requisitos, prohibiciones, órdenes de saneamiento y sanciones.

Por ejemplo, en cuanto al aire y agua, resultan de alta relevancia los valores límites de la contaminación máximamente permitida y, además, la imposición de éstas por parte de las autoridades, pero en ambas disciplinas América Latina no alcanza los niveles protectores establecidos en los Estados precursores. Además, en el derecho de basuras, la normatividad continúa permitiendo el antiguo esquema de la deposición en extensos basureros urbanos, tolerando contaminaciones graves del suelo, agua y aire. Los conceptos de una economía cíclica se encuentran todavía en una fase incipiente. De igual forma, la selva Amazónica continúa siendo deforestada, como si las leyes protectoras no existieran. Asimismo, el derecho local de protección del clima mundial contra la amenaza por las emisiones de dióxido de carbono que llevan al calentamiento global, no supera las manifestaciones de la buena voluntad en países donde gigantescas empresas estatales producen las versiones básicas de los gases de efecto invernadero -petróleo y gas natural-.

Entre las excusas más frecuentemente planteadas para justificar la materialización subóptima del derecho ambiental en Latinoamérica, se detectan argumentaciones con los altos costos y la escasez presupuestal, las rivalidades de competencias, los desacuerdos intra-administrativos, las dificultades en lograr una contratación pública sin errores, las preocupaciones sobre efectos negativos en el clima inversionista, la primacía del desarrollo industrial -al estilo de querer desarrollarse primero para reparar posteriormente los daños con las ganancias- y la conservación o creación de puestos de trabajo. Muchos funcionarios y ciudadanos latinoamericanos han interiorizado las teorías económicas del siglo XX y el sueño estadounidense de un crecimiento económico progresivo y desarrollismo ilimitado hasta el cielo en la Tierra para todos, sin abrirse enteramente a los debates científicos de la sostenibilidad ambiental en un 
planeta limitado. En el fondo, es una experiencia dolorosa para los países semi-industrializados aprender que el camino hacia la riqueza colectiva mediante la combustión masiva de carbón mineral y petróleo, es decir, el camino histórico de los Estados más exitosos del industrialismo, es inevitablemente bloqueado para la futura transformación de ellos mismos. Pero de este choque, puede crecer también una nueva autoestima más realista con base en no querer repetir los errores de sobredesarrollo del supuesto primer mundo: a fin de cuentas, los más sostenibles pueden tener el aliento más largo.

\section{e. El constitucionalismo de la diversidad étnica}

Otra fuerte corriente del ECDSA de la sexta ola fue el constitucionalismo étnico que rompió con la tendencia del liberalismo del largo siglo XIX de homogeneizar la diversidad cultural y lingüística del Antiguo Régimen dentro de la unidad de la nación masificada, individualizada, igualitaria e hispanoparlante. El enfoque en un conjunto de individuos con iguales derechos había representado, seguramente, un concepto integrador y no excluyente; no obstante, se pagó el precio de la extinción de numerosos idiomas, como el muisca del altiplano cundiboyacense de las zonas centrales de Colombia.

\section{a. Los derechos colectivos de los pueblos indígenas}

La tendencia a reconocer la existencia de etnias con un perfil lingüístico-cultural diferente del ideal euro-ibérico, tiene una antehistoria, pues, a partir de la carta ecuatoriana de 1897, apareció esporádicamente en normas constitucionales dedicadas a algún nivel de protección especial, mientras el multilingüismo se incorporó por ejemplo en la Constitución de Paraguay de 1967. Estas tendencias se profundizaron y se difundieron alrededor de 1990. El redescubrimiento de la diversidad cultural coincidió, primero, con las tendencias análogas del post-nacionalismo en Europa, por ejemplo, en España a partir de la constitución transformadora de 1978; segundo, ocurrió en concordancia 
con las exigencias de varios movimientos sociales indígenas; tercero, se inspiró en los esfuerzos de las Naciones Unidas y, cuarto, el derecho étnico sirvió como un catalizador para reconfigurar el nacionalismo hispanoamericano con nuevas connotaciones no tan eurocéntricas.

Analizando el documento fundador del nuevo étno-constitucionalismo, la Constitución de Colombia de 1991, llama la atención que la constituyente permitió la participación de representantes indígenas, de modo que la carta reconoció -más allá del idioma nacional castellano- que "las lenguas y dialectos de los grupos étnicos son [...] oficiales en sus territorios"113. En términos cuantitativos, esto afectó a una pequeña minoría que, según los censos oficiales de 1973 a 1993, oscilaba alrededor del $1 \%$ de la población y, en la era del constitucionalismo étnico, ascendió estadísticamente a un 4, $4 \%(2018)^{114}$, todo muy por debajo del tercio de la población identificada a mediados del siglo XIX como campesinado indígena. La zona lingüística indígena mayor de la tradición colombiana, la de los muiscas del central altiplano cundiboyacense, había pasado por la asimilación completa, incluyendo el memoricidio, de modo que sus descendientes se percibieron ahora como colombianos mayoritarios, sin perfil particular. Por lo tanto, el constitucionalismo étnico de Colombia tuvo que limitarse a las ex sociedades pre-estatales de las tierras bajas, que habían entrado en contactos reales con el poder estatal desde los años 1950.

Según la carta de 1991, el Estado colombiano pretendió "protege[r los restos de] la diversidad étnica y cultural de la Nación”. Tres elementos llaman la atención: primero, se garantizaron "las tierras comunales de grupos étnicos", superando definitivamente las políticas del alto liberalismo de individualizar la propiedad raíz campesina o del alto nacionalismo de tratar las tierras de las tribus salvajes en las llanuras bajas como

\footnotetext{
${ }^{113}$ Art. 10 de la CP de Colombia de 1991.

114 Las cifras se basan en el autorreconocimiento, es decir, cambian según la estimación de una cierta etnia en un cierto momento que el DANE evalúe con frecuencia.
} 
res nullius bajo la titularidad superior del Estado (baldios). En vista del éxito de la reforma agraria liberal del siglo XIX, esto afectó solamente a pocos resguardos virreinales conservados en las cordilleras del sur, mientras el efecto principal consistió en el reconocimiento de los derechos de las ex sociedades preestatales de las tierras bajas sobre sus tierras. Segundo, la carta en mención reconoció explícitamente la autonomía jurídica de las sociedades tribales con "derechos especiales" y "funciones jurisdiccionales", pero solo si las respectivas normas "no sean contrarios a la Constitución y leyes de la República" bajo el control de la Corte Constitucional, aceptando de tal manera la existencia de una multitud de pequeñas entidades semi-encerradas con su propio gobierno y justicia -incluyendo penal- por dentro del marco de la sociedad nacional, en alguna cercanía estructural a la lógica descentralizada del derecho de la Monarquía de las Españas e Indias del Antiguo Régimen. Tercero, Colombia introdujo una representación fija de los indígenas en el Senado con dos miembros, retomando así otro elemento del protoconstitucionalismo del Antiguo Régimen europeo con su lógica de la representación estamental y grupal ${ }^{115}$.

Casi paralelamente al desarrollo colombiano, México postuló, a través de la reforma constitucional de 1992, "la composición pluricultural" de la nación, "sustentada originalmente en sus pueblos indígenas", lo que se profundizó por la reforma integral indígena de 2001. En el país azteca concierne todavía a ciertos restos de la identidad cultural del antiguo campesinado del altiplano en la dimensión del 9,4\% de la población. De modo análogo, la Constitución de Paraguay de 1992 prolongó la decisión temprana de 1967 y declaró su patrón de identidad al estilo de "un país pluricultural y bilingüe" del español y el guaraní, lo que correspondió también con la excepcional realidad

\footnotetext{
${ }^{115}$ Arts. 7, 63, 72, 171 y 246 de la CP de Colombia de 1991. CCC, T-254/94. Cfr. Borrero, Derechos multiculturales, pp. 226 y ss; Kuppe, Indigene Rechtsprechung, pp. 10 y ss; Ruíz, Encuentros y desencuentros, pp. 437 y ss; Sánchez, Justicia y pueblos indígenas, pp. 81 y ss; Semper, Los derechos de los pueblos indígenas, pp. 97 y ss.
} 
bilingüe de casi todo este pueblo que desciende de la simbiosis fundador en los señoríos jesuíticos de la era virreinal ${ }^{116}$.

De igual forma, se señalan los tres países centroandinos con un denso campesinado de tipo altiplano que había hablado todavía en el siglo XIX lenguas indígenas. La Constitución política del Perú de 1993 reconoció la autonomía jurídica de los pueblos indígenas, lo que estuvo en la tradición de la autogestión reconocida en la carta precursora de 1979 con raíces desde 1919, al igual que la constitución boliviana de 1995 acogió la autonomía jurídica y también lo hizo la carta ecuatoriana de 1998. En el Perú, benefició al $32 \%$ del demos, pero en Bolivia a una mayoría calificada del 66,2 \% de la nación, mientras en el Ecuador hubo solamente restos de tal identidad en la dimensión del 6,8\% de los ciudadanos ${ }^{117}$.

En cambio, fracasó el proyecto de reforma de la constitución guatemalteca de 1999, pues el pueblo sistemáticamente desinformado fue dirigido a votar en el referéndum de ese año en contra de cambios que hubieran promovido lo social, lo indígena y la paz, pese a que aproximadamente el $40 \%$ de los ciudadanos correspondió a la comunidad lingüística y cultural de los mayas. Tampoco en Chile el constitucionalismo étnico logró imponerse, pues las diversas reformas de la carta de origen dictatorial rechazaron todo reconocimiento del 4,6 \% de indígenas, en particular mapuches, al nivel de la norma de normas ${ }^{118}$.

\section{b. ¿Sincretismo occidental-incaico en la zona centro-andina?}

En el primer decenio del siglo XXI, la zona centro-andina elaboró la variante más profunda y detallada del derecho étnico, en

\footnotetext{
116 Decretos mexicanos re reforma constitucional de 1992 y 2001; art. 140 de la CP de Paraguay de 1992. Información lingüístico-cultural (tb. para los siguientes países): Albó et al., Atlas sociolingüístico de América Latina I, p. 68.

117 Art. 149 de la CP del Perú de 1993; art. 171 de la CP de Bolivia de 1995; art. 191 de la CP del Ecuador de 1998.

118 Kuppe, Indigene Rechtsprechung u. staatl. Recht, pp. 15 y s.
} 
particular en forma de la Constitución del Ecuador de 2008 y en aquella de la Constitución de Bolivia de 2009. Ambas cartas contuvieron figuras éticas asociadas con la tradición incaica, como la deidad de la madre tierra y el buen vivir. De tal manera, las constituyentes formularon constructos de legitimidad que velaron bajo la apariencia hinchada de visibilizar y liberar supuestas raíces pre-occidentales. Sin embargo, en vista de la falta de toda memoria confiable de los ex incas occidentalizados desde hace medio milenio, excepto la lengua, se trató precisamente de un nuevo constructo, derivado del romanticismo - de raíz occidental- que reconfiguró conceptos de la muy actual transformación ambiental -también de raíz occidental- según el mito de querer volver a supuestas raíces propias más armónicas. En vista de estos desequilibrios y distorsiones teóricas, fue irreal lograr un nuevo sincretismo constitucional entre lo occidental e incaico, sino que ocurrió la inclusión de palabras poéticas al extendido pluralismo tridimensional liberal-social-ambiental de entonces que señalan -y esto es lo revolucionario- el reconocimiento de la prioridad relativa del componente ecológico.

\section{c. Autonomía neo-segmentaria y expansión de la civilización industrial}

Pese al idealismo indigenista y neo-segmentario del derecho constitucional desde los años 90, sobrevivieron fuertes amenazas existenciales para las micro-sociedades selváticas. La más subliminal es el poder homogeneizador de la civilización industrial en sí misma, pues no es fácil eludirse de fuerzas seductoras difundidas por la educación popular, los imaginarios televisivos, la atracción de modas de consumo o la gravitación urbana que motiva migraciones hacia la ciudad.

Otro tipo de amenaza tuvo que ver con los intereses de explotación neo-extractivista en nombre de dicho desarrollo industrial. Cuando el Estado otorgó generosamente concesiones para grandes proyectos de minería de energía fósil u otros recursos, represas hidroeléctricas o biocombustibles, delegando 
su derecho originario en el subsuelo a grandes empresas nacionales y transnacionales, los derechos colectivos de las tribus en sus tierras ancestrales salieron frecuentemente perdiendo. En la experiencia de Colombia y Perú, tampoco ayudó mucho la garantía del derecho a la consulta previa, pues en las ponderaciones concretas de las autoridades y jueces, resultó invencible el argumento de la predominancia de los intereses energéticos y económicos nacionales ${ }^{119}$. Por ejemplo, es emblemática la iushistoria de la gigantesca mina transnacional de carbón de Cerrejón que, desde su apertura en 1981, satura el hambre de los europeos en este tipo de energía fósil y muestra una acumulación de transgresiones frente al pueblo wayú de la Guajira, por las cuales resultó responsabilizada judicialmente en serie - por degradar el hábitat de los wayú, contaminar su agua, secar arroyos, degradar la salud y no respetar la consulta previa-, pero nadie puede afirmar que estas sentencias hubieran alcanzado algún efecto significativo de mejora ${ }^{120}$.

\section{d. Los límites sistémicos de la autonomía jurídica neo- segmentaria en el Estado constitucional}

En este apartado, la pregunta dirigente es la de la profundidad y calidad de la nueva autonomía jurídica y jurisdicción especial confiada a los pueblos indígenas desde los años 90. Un primer problema lo encarnó la cuestión de la autenticidad de la afirmada tradición jurídica particular, pues si una (ex) sociedad tribal de las tierras bajas empezó a reemplazar el sistema penal compensatorio de tipo pre-estatal por sanciones públicas más allá del destierro clásico -aplicando ahora penas corporales, el trabajo forzado, o incluso la cárcel-, la misma aplicó evidentemente algo proveniente de una fuerte transculturación reciente bajo influencias transformadoras recibidas de

\footnotetext{
${ }^{119}$ Art. 330 § de la CP de Colombia de 1991; Ley peruana 29.785 de 2011; CCC, Sent. SU123/18. Vid. Rodríguez, De la consulta previa al consentimiento libre, pp. 46 y ss, 65 y ss, 147 y ss, 206 y ss, 215 y ss.

${ }^{120}$ Colectivo de Abogados J. Alvear R., Diez verdades sobre Carbones de Cerrejón.
} 
su entorno estatal, pero de modo desconfigurado y retroalimentado con elementos típicos de épocas anteriores, creando algo similar al derecho estatal de primera generación como aquel del segmentarismo jurídico del Medioevo europeo.

En segundo lugar, en la medida en la que el indigenismo romántico no diferenció y entregó la autonomía tribal análogamente a las sociedades no tribales del campesinado de los altiplanos, pese a que habían sido culturalmente adaptadas desde siglos, excepto la lengua, se abrió otra puerta hacia un neo-segmentarismo jurídico de corte Antiguo Régimen, en el cual consejos campesinos pudieron tomar decisiones judiciales según el sentimiento popular y fuera de las garantías del Estado constitucional moderno. Los últimos evidentemente no dispusieron de ninguna memoria auténtica, transmitida desde la era virreinal y menos desde la era prehispánica, es decir, efectivamente se construyó algo novedoso meramente seudotradicional sin poder basarse en fuentes confiables. Además, surgió el problema de igualdad en comparación con las comunidades campesinas del mismo altiplano que habían cambiado su identidad lingüística hacia el castellano, pues no recibieron ningún privilegio judicial semejante.

El tercer problema se refirió al alcance permitido de la autonomía neo-segmentaria, lo que se concretó a través del control judicial por parte de las altas cortes republicanas. Pese al empaque de muchas sentencias en generalidades con un sonido benevolente para la autonomía étnica como tal, siempre que el derecho consuetudinario tribal colisionaba materialmente con los derechos fundamentales del constitucionalismo moderno, por ejemplo, al permitir que una niña de once años contrajera matrimonio, el Estado defendía inequívocamente el universalismo iusnatural e intolerante de la Ilustración, amparando en el caso indicado los derechos a la niñez en contra de la voluntad de todos los familiares involucrados incluyendo la menor misma. No parece mayor la tolerancia efectiva para la poligamia y otras prácticas acentuadas del patriarcado tradicional. Tampoco se articuló ninguna tolerancia material ni para 
tradiciones provenientes del belicismo inter-tribal de la Amazonía -como la caza de cabezas o la esclavización de enemigos vencidos, consideradas incompatibles con la paz territorial del Estado moderno-, ni para los conceptos penales de corte tribal o neo-medieval -considerados arbitrarios, no previsibles, crueles, inhumanos, degradantes, expropiatorios (confiscación de bienes) o supra-individuales (caso del destierro completo de la familia del malhechor) según las gafas jurídicas de la Ilustración-, ni para las pruebas mágicas de tipo ordalía -evaluadas como irracionales y violadoras de las garantías constitucionales del debido proceso-. De tal manera, el supuesto pluralismo jurídico no estuvo dispuesto a sacrificar nada sustancial de los logros apreciados de la historia del derecho europea y americana de los últimos dos siglos y medio ${ }^{121}$.

A fin de cuentas, las repúblicas solo admitieron aquellos elementos culturales étnicos que resultaban simpáticos según el filtro de la ética liberal, social y ambiental, tales como el uso de vestidos coloridos y la práctica de bailes exóticos. No se sobrepasó significativamente lo folclórico. Sintetizando, el neo-pluralismo jurídico produjo expectativas con las cuales el Estado de Derecho moderno no puede cumplir sin abandonar a sí mismo.

\section{La integración continental y la protección supranacional de valores constitucionales}

\section{a. La benevolencia constitucional para la integración iberoamericana}

Otra tendencia clave de la sexta ola del constitucionalismo iberoamericano fue la creación de estructuras trans y supranacionales que promueven, fortalecen y homogeneízan los valores

\footnotetext{
${ }^{121}$ Discusión en: Ariza, Coordinación entre sistemas jurídicos; Borrero, Derechos multiculturales, pp. 243 y ss; Kuppe, Indigene Rechtsprechung u. staatl. Recht, pp. 30 y ss; Pacheco, Las penas 'salvajes', pp. 233-252; Ruíz, Encuentros y desencuentros., pp. 452 y ss, 457 y ss; Sánchez, Justicia y pueblos indígenas, pp. 147 y ss; Semper, Los derechos de los pueblos indígenas, pp. 173 y s.
} 
constitucionales. Precisamente, las cartas renunciaron al soberanismo clásico y reconocieron las finalidades de la integración continental: lo hizo por ejemplo la Constitución de Colombia de 1991 al prever la conformación de "una comunidad latinoamericana de naciones" y establecer "elecciones directas para [...] el Parlamento Andino", al igual que la Constitución de Venezuela de 1999 "favorecerá la integración latinoamericana [...] hacia la creación de una comunidad de naciones", mientras la carta ecuatoriana de 2008 "impulsa prioritariamente la integración política, cultural y económica de la región andina, de América del Sur y de Latinoamérica”. Efectivamente, el ideal de la integración latinoamericana ha llevado a múltiples intentos con denominaciones, estructuras y fines diferentes sin coordinar siempre de modo eficaz las respectivas sinergias ${ }^{122}$.

\section{b. Valores comunes y 'bloque de constitucionalidad'}

Llama la atención que la parte iusfundamental de las constituciones de la sexta ola mostró un alto grado de homogeneización con los catálogos universalizados de derechos humanos en el marco de las Naciones Unidas a partir de 1966. Esto se complementó por un aseguramiento adicional en forma de la nueva figura del bloque de constitucionalidad que presentó la posibilidad de entender normas fuera del texto constitucional como parte del mismo ${ }^{123}$. Al respecto, la reforma constitucional argentina de 1994 expuso con mucha claridad: "La Declaración Americana de los Derechos y Deberes del Hombre; la Declaración Universal de Derechos Humanos; la Convención Americana sobre Derechos Humanos; el Pacto Internacional de Derechos Económicos, Sociales y Culturales; el Pacto

\footnotetext{
${ }^{122}$ Art. 227 de la CP de Colombia de 1991; art. 153 de la CP de Venezuela de 1999; art. 416 $\mathrm{n}^{0} 11$ de la CP del Ecuador de 2008. Cfr. Morales, Protección supranacional de la democracia, pp. $77 \mathrm{ss}$.

${ }^{123}$ Véase Manuel E. Góngora M., “La difusión del bloque de constitucionalidad en la jurisprudencia latinoamericana", en Bogdandy et al., Ius Constitutionale Commune, pp. 145-180; Rodrigo Uprimny Y., El bloque de constitucionalidad en Colombia, 2005.
} 
Internacional de Derechos Civiles y Políticos y su Protocolo Facultativo; [... y otros tratados], tienen jerarquía constitucional, no derogan artículo alguno de la primera parte de esta Constitución y deben entenderse complementarios de los derechos y garantías por ella reconocidos"124.

De tal manera, Iberoamérica superó la relevancia secundaria de los Pactos de 1966 durante la quinta fase y evitó caprichos como los alemanes que marginaron los pactos iushumanos al rango de meras leyes simples por debajo del nivel constitucional. Nada de esto puede ser explicado adecuadamente por las ofertas teóricas de inicios del siglo XX -monismo y dualismo-, sino que es importante reconocer una nueva figuración pos-soberana de una estatalidad abierta en el marco de una 'jerarquía' normativa a gran escala con múltiples polos supranacionales, interdependencias y retroalimentaciones que espera todavía su teorización decisiva. En realidad, se forman nuevos niveles de una estatalización parcial y rudimentaria por encima de las naciones 'clásicas' del siglo XIX, en los niveles global y hemisférico, bajo una complementación cooperativa, en lo que no hay ninguna contradicción frente a la antigua fundamentación universalista de los derechos del hombre y ciudadano, ahora humanos.

\section{c. La jurisdicción hemisférica en derechos humanos}

Un desarrollo complementario al perfeccionamiento del Estado iusfundamental, puede reconocerse en la creación contractual de las dos jurisdicciones casi hemisféricas en asuntos de derechos humanos. Para el tema de este artículo, se señala la Corte Interamericana de Derechos Humanos de 1979 con sede en San José de Costa Rica que se basa en la Convención Americana sobre Derechos Humanos, en vigor desde $1978^{125}$. La competencia contenciosa y obligatoria de esta jurisdicción

\footnotetext{
${ }^{124}$ Art. $75 n^{0} 22$ de la CP de Argentina de 1994. Vid. Bogdandy, lus Constitutionale Commune, p. 8; Ferreyra, Fundamentos constitucionales, pp. 274 y ss; Morales, El Estado abierto, p. 95.

${ }^{125}$ Véase Binder, Auf dem Weg zum lat.am. Verf.gericht? pp. 1-29; Carazo, El sistema interamericano de ddhh, pp. 231-285; Vivas \& Cubides, Diálogo judicial transnacional, pp. 184-204.
} 
hemisférica -que es precisamente latinoamericana, debido al rechazo por el soberanismo estadounidense y canadiense-, fue aceptada por Costa Rica en el año 1980, por Perú, Venezuela y Honduras en 1981, por Argentina y Ecuador en 1984, por Colombia en 1985, por Guatemala en 1987, por Chile y Panamá en 1990, por Nicaragua en 1991 y por Bolivia y Paraguay en 1993. Dicha integración fue subrayada por normas constitucionales explícitas en países como Brasil en 1988, Chile en 1989, Colombia en 1991, Paraguay en 1992), el Perú en 1993 y el Ecuador en $1998^{126}$.

Preguntando por la legitimidad, puede decirse que, según sus raíces contractuales, la Corte Interamericana de Derechos Humanos juzgó oficialmente en nombre de la comunidad zonal de Estados, pero efectivamente en nombre de la comunidad de los respectivos pueblos en contra de uno de los miembros estatales $^{127}$. Como toda corte constitucional nacional, encarnó un elemento aristocrático al estilo de un consejo de sabios y guardianes jurídicos sin legitimación democrática directa, pero en la práctica comprobó su ética, funcionalidad y necesidad, actuando estilísticamente entre la espada y la moderación. Hay que insistir que los derechos humanos y fundamentales solo son fuertes si se entrega su vigilancia a los jueces. Se dirigen contra todo tipo de poder, sea un rey, un dictador o una colectividad: por lo tanto, son esencialmente contramayoritarios, también en contra de un demos que aprendió a percibir las violaciones del pasado como supuestamente oportunas y necesarias.

Analizando la jurisprudencia de la jurisdicción común latinoamericana en derechos humanos, se detectan las cifras más altas de casos contenciosos en tres países: 90 en Perú, 45 en Guatemala y 37 en Colombia. Por su parte, el campo medio se compone de 28 casos contenciosos en Ecuador, 27 en Venezuela,

\footnotetext{
${ }^{126}$ Tít. X art. 7 de I CP de Brasil de 1988; art. 5 n² 2 de la CP de Chile (versión de1989); art. 93 de la CP de Colombia de 1991; art. 142 de la CP de Paraguay de 1992; art. 205 de la CP del Perú del 1993; arts. 18-19 de la CP del Ecuador de 1998.

127 Sobre esta pregunta: Bogdandy \& Venzke, ¿En nombre de quién? pp. 299 y ss.
} 
23 en Honduras y Argentina, 13 en México, 11 en Chile y El Salvador y 9 en Bolivia y Paraguay. Además, en el grupo de baja virulencia anti-iushumana, se detectan nada más que cuatro casos en Costa Rica y tres en Uruguay. Un número significativo de estas sentencias se dedicó a violaciones muy graves de derechos humanos, incluyendo abusos autocráticos duros y masacres masivas $^{128}$.

Entre los casos más llamativos figura el peruano del año 2001, en el cual la Corte Interamericana de Derechos Humanos revisó la destitución de los magistrados del Tribunal Constitucional del Perú por parte del Presidente autocrático Fujimori en 1997 y la declaró una violación intolerable de las garantías judiciales, de la protección judicial y de los derechos políticos de los jueces. En el mismo año, los magistrados juzgaron la responsabilidad del Estado peruano por la masacre de Barrios Altos en 1991 con 15 homicidios cometidos por agentes del Estado y derogaron la legislación de autoamnistía de 1995, impidiendo así la impunidad de los abusos militares y policiales en el conflicto interno de este país. Estas sentencias prepararon decisivamente el juicio penal nacional contra Fujimori en 2009.

También fue emblemático que, en 2002, la Corte Interamericana de Derechos Humanos condenó a Venezuela por los 276 muertos de la masacre militar y policial del Caracazo que había ocurrido en 1989, frente a las protestas populares contra la política 'neoliberal' del gobierno de Pérez. En 2005, siguió la condena de Chile en el sentido de subrayar la imposibilidad de amnistiar delitos de lesa humanidad, invalidando un relicto precario proveniente de la dictadura de Pinochet.

Con respecto a Guatemala y Colombia, la Corte Interamericana de Derechos Humanos tuvo que dedicarse a concentraciones de masacres sin precedentes. En varias sentencias a partir de 2004, participó en reconstruir el genocidio maya con su pico

\footnotetext{
${ }^{128}$ Cifras según la página oficial de la Corte IDH: http://www.corteidh.or.cr/cf/Jurisprudencia2/index.cfm?lang=es (30.11.2019). Todas las sentencias que se citan subsiguientemente, se encuentran en esta página.
} 
en 1982 y motivó al Estado guatemalteco a aceptar su responsabilidad $^{129}$. También en varias sentencias desde 2004, expuso que múltiples masacres de los paramilitares colombianos, ocurridas principalmente entre 1987 y 1997, habían tenido lugar dentro del marco de responsabilidad del Estado colombiano, indicando la perspectiva muy incómoda para dicha república de haber practicado una especie de terror estatal privatizado contra segmentos de la población civil. Frente a Colombia, se agregaron las condenas de 2010 y 2018 que tematizaron el politicidio sistemático en varios miles de miembros del partido político de izquierda Unión Patriótica, efectuado entre 1985 y 2002. De igual forma, la Corte condenó a Colombia por operaciones atroces de sus fuerzas armadas: primero, en 2012, por un bombardeo de la Fuerza Aérea de 1998, que dejó 17 civiles muertos entre los cuales había seis niños; segundo, en 2014, por las desapariciones forzadas, torturas y ejecuciones extralegales en la toma militar del Palacio de Justicia, ocurrida en 1985; tercero, en 2018, por los llamados falsos positivos, es decir, múltiples "ejecuciones extrajudiciales [...] con un modus operandi caracterizado por la muerte de civiles posteriormente presentados como miembros de grupos armados ilegales dados de baja en combate"130.

En los diversos casos particulares, se comprobó la limitación material de la soberanía estatal que ahora no pudo escaparse de las sentencias iushumanas incómodas que tematizaron y visibilizaron vergüenzas y traumas nacionales. Más allá de la renuncia contractual a la respectiva esfera de la soberanía judicial, resultó casi inexorable la presión por la autoridad moral del tribunal iushumano. En última instancia, pudo observarse una mediatización parcial por debajo de una nueva soberanía judicial común latinoamericana.

\footnotetext{
129 Vid. Núñez \& Canal, Las masacres de Río Negro, pp. 121-150.

130 Cfr. Duarte H. et al., La implementación del Acuerdo final de paz, pp. 287 y ss; Jaramillo, Violaciones a los ddhh en el conflicto armado, pp. 201-216; Vivas \& Toro, Estudio sobre el cumplimiento de la sentencia Masacre de Mapiripán contra Colombia, pp. 37-56.
} 
Sintetizando, se evidencia que América Latina promueve su ius commune en derechos humanos como una ética común de alta estimación, aunque no todo halcón superviviente de la anterior era del anti-constitucionalismo aprendió a compartirlo.

\section{d. Tendencias opuestas: los jueces de sombra del anti-constitucionalismo neoimperial-'neoliberal'}

La internacionalización de la sexta ola no se limita a los derechos humanos, sino que parece ser acompañada por un hermano negro. Se habla de una justicia especial creada para defender los intereses hegemónicos del sistema mundo capitalista, precisamente de los países del núcleo industrial que pretenden mantener grandes huellas ecológicas de extensión planetaria y centrar el metabolismo social del globo limitado a sí mismos.

El mecanismo central son los tribunales de arbitraje -especialmente el Centro Internacional de Arreglo de Diferencias Relativas a Inversiones (CIADI) del Banco Mundial- que pueden fallar multas en la altura de varios millones de dólares contra Estados, si una empresa transnacional, típicamente con sede y/o accionistas principales en Europa occidental o Norteamérica, ve en peligro sus expectativas de ganancias. Con base en los desiguales tratados de protección de inversiones, se estableció una justicia paralela, secreta y poderosa que compite, en términos de calidad y parcialidad, con la santa inquisición del Antiguo Régimen. Se orienta en las cláusulas estandarizadas de los tratados de protección de inversiones, tratando privilegios empresariales frente al constitucionalismo social y ambiental como plenamente válidas, sin interesarse por el carácter iusnatural e iushumano de las respectivas garantías en cuestión. En particular, abusan del discurso polémico sobre la supuesta debilidad de los derechos de propiedad en América Latina, creando analogías aventureras que confunden sistemáticamente concesiones públicas que delegan tareas estatales con una presumida propiedad privada. Para justificar supuestos deberes estatales 
de indemnización, extienden la categoría de expropiación a cualquier intervención normativa o administrativa con impactos en expectativas de ganancias. Bajo la elusión del monopolio de justicia del Estado constitucional, se juzga en nombre del capital en contra de los derechos humanos de millones de personas.

Empíricamente, no es posible comprobar que los tratados de protección de inversiones hubieran atraído más empresas extranjeras, pero se encuentran muchas demandas con las que las empresas maniobraron Estados en situaciones difíciles. Un primer caso llamativo ocurrió en 2000, cuando un tribunal de arbitraje condenó a México a indemnizar a la empresa estadounidense de residuos tóxicos Metalclad con 16,7 millones de dólares por una supuesta expropiación indirecta, simplemente porque la legislación ambiental, en conformidad con la constitución, había imposibilitado la construcción de un vertedero peligroso, reduciendo expectativas de ganancias. Además, en 2012, el CIADI condenó a Ecuador a pagar 1.770 millones de dólares (finalmente 1.062 millones) a la petrolera estadounidense Occidental (Oxy), pues los jueces de sombra no aceptaron como proporcional que el gobierno había declarado la caducidad de la concesión sin indemnización en vista de incumplimientos legales y contractuales, mientras en 2014 fue condenado Venezuela a pagar una suma en la misma categoría a la petrolera estadounidense Exxon Mobil en otro contexto de revocación de concesión. Además, en 2010, la rama suiza de la empresa transnacional Philip Morris demandó la legislación de salud antitabaco de la república del Uruguay, pero sorprendentemente perdió en 2016. Por su parte, la petrolera estadounidense Chevron-Texaco pretendió escaparse de la sentencia ecuatoriana de 2011 -confirmada por la Corte Nacional de Justicia en 2013 y la Corte Constitucional en 2018- sobre indemnizaciones por evidentes daños ambientales y perjuicios de grupos étnicos en la zona selvática del lago Agrio, instrumentalizando la parcial justicia de protección de inversiones, de modo que, en 2018, el Tribunal Arbitral de La Haya emitió un laudo pro-empresarial y anti-iushumano que pidió la anulación 
de la sentencia ecuatoriana bajo la afirmación que la misma hubiera sido obtenida a través "de fraude procesal, falta judicial y corrupción dentro de la Corte". Para los Estados semi-industrializados de América Latina, las indemnizaciones exorbitantes ordenadas en el exterior, pueden llevar a situaciones precarias. No es ajeno de la realidad reconocer en esta justicia de sombra la punta de lanza del sistema hegemónico de los centros mundiales del industrialismo para poner Estados insumisos de rodillas.

Varios gobiernos afectados intentaron rechazar las sentencias señaladas, aunque resultó limitado el espectro de soberanía real frente al núcleo industrial del mundo que dispone de múltiples canales de presión. Ante estas experiencias, varios países de Hispanoamérica se retiraron del sistema de arbitraje -Bolivia en 2007, Ecuador en 2010 y Venezuela en 2012-, mientras Brasil había sido tan sabio de nunca incluirse. Al respecto, el artículo 422 de la constitución ecuatoriana de 2008 decidió que "[n]o se podrá celebrar tratados o instrumentos internacionales en los que el Estado ecuatoriano ceda jurisdicción soberana a instancias de arbitraje internacional"131.

\section{A modo de conclusión: constituciones extensas, idealistas, transformadoras y parcialmente normativas}

Una primera observación general del ECDSA de la sexta ola es que la extensión de las constituciones latinoamericanas ha crecido considerablemente, alcanzando en el caso de Ecuador 444 artículos (2008) y en Bolivia 411 (2009), incluyendo un enorme grado de detallismo en materia de derechos fundamentales. Aunque no es falso advertir que esta predisposición retome algunas tendencias del idealismo de la primera ola

131 ICSID Cases ARB(AF)/97/1, ARB/06/11, ARB/07/27; ARB/10/7; PCA Case 2009-23 (7.145). Cfr. Ahrens, La transformación de la juridicidad, pp. 137-154, 145 y ss; Boeglin, ICSID and Latin America; García, Caso Oxy, Skovgaard, Sacrificing Sovereignty by Chance, pp. 29 y ss; Sornarajah, Mutations of Neo-Liberalism, pp. 203-232. 
del constitucionalismo hispanoamericano -se pueden citar los 397 artículos de la Constitución del Estado de Cartagena de Indias de 1812-, es más preciso ver el trasfondo principal en el enorme crecimiento de los deberes estatales en el marco de la transformación a la sociedad (post) industrial del último siglo XX y XXI. De igual forma, puede indicarse que los poderes constituyentes contemporáneos quieren tomar por sí mismos las grandes decisiones sobre el perfil de la república en vez de delegar cartas blancas al poder legislativo. Sin duda, la detallada longitud mejora la transparencia de la organización y los valores del Estado. En cambio, una constitución breve como la Grundgesetz alemana de 1949 con sus 146 artículos (202 con reformas), es menos autoexplicativa y requiere del estudio intenso del derecho administrativo y de los comentarios científicos para ser entendible. Un futuro historiador podría reconstruir mucho más fácilmente de las cartas iberoamericanas lo que quiere ser el Estado de inicios del siglo XXI que de las cartas de la Europa noralpina con su tendencia al understatement modesto.

En particular, se enfatiza la tendencia latinoamericana a constitucionalizar cada vez más valores, derechos y fines estatales en los ámbitos liberal, social, ambiental y cultural, rechazando de tal manera el modelo de la mera constitución organizacional. En alguna cercanía al estilo de las primeras constituciones hispanoamericanas, como la tunjana de 1811, la venezolana de 1819 o la chilena de 1823, se redescubre también el constitucionalismo ético, así, muy manifiestamente, en la carta de Bolivia de 2009 donde el Estado promueve: "no seas flojo, no seas mentiroso, ni seas ladrón", además del "vivir bien", la "vida armoniosa", la "vida buena", la "tierra sin mal" y el "camino o vida noble", llevando a la siguiente conclusión en su artículo 8: "El Estado se sustenta en los valores de unidad, igualdad, inclusión, dignidad, libertad, solidaridad, reciprocidad, respeto, complementariedad, armonía, transparencia, equilibrio, igualdad de oportunidades, equidad social y de género en la participación, bienestar común, responsabilidad, justicia social, distribución y redistribución de los productos y bienes sociales, para vivir bien". 
El estilo idealista y casi poético de las constituciones contemporáneas de América Latina, lleva con frecuencia a la pregunta crítica de si las mismas representen algo real o mera fachada. En este artículo se quiere sostener la opinión de que ellas pertenecen tendencial y típicamente -según la tipología ontológica elaborada por Loewenstein con sus tres categorías de las constituciones normativas, nominalistas y semánticas ${ }^{132}$ al primer subgrupo, pues obviamente no se trata de textos de disfraz para esconder hábilmente dictaduras militares, cleptocracias crudas o sistemas unipartidistas. No son dedicadas ni a engañar al pueblo propio ni a meros fines de la reputación internacional. Tampoco pueden hablarse de meros textos ficticios orientados al futuro lejano de ex autocracias casi eternas que entrarían en una eventual primera experiencia de democratización significativa -así a diferencia de un posible escenario futuro de Asia-; menos son normas supremas ilusorias para organizar ex sociedades pre-estatales africanas donde la tercera o cuarta generación pos-tribal trabaja todavía en la generación de la mentalidad básica para lograr la estatalización originaria. En cambio, hay que partir del marco socio-histórico de algunos de los Estados constitucionales más antiguos del mundo con una cultura republicana consolidada.

En este marco, es evidente que se pretendieron consolidar cartas normativas en la medida viable -por lo menos según la voluntad de las constituyentes, jueces constitucionales y profesores en derecho, pero también de la mayor parte de los Presidentes y congresistas-. Típicamente, hay un amplio consenso pro-sistémico y se entiende la constitución como categoría clave de la identidad colectiva, por lo menos abstracta y sumariamente, lo que no significa la ausencia de conflictos y transgresiones que, en el mejor de los casos, son resueltos por la justicia constitucional, al igual como en otros Estados constitucionales del mundo. Generalmente, las disposiciones de la organización estatal alcanzan la mayor fuerza normativa. Tampoco es tan

132 Loewenstein, Verfassungslehre, pp. 151 y ss. 
preocupante la realidad de los derechos liberales que requieren esencialmente de un dejar intervenir del Estado. En cambio, los problemas mayores se manifiestan en los valores constitucionales que requieren de inversiones estatales para realizarse $-\mathrm{y}$ de la respectiva tributación de los ciudadanos económicamente potentes-, es decir, en las esferas del constitucionalismo social y ambiental.

No es contradictorio, interpretar las cartas al mismo tiempo como constituciones transformadoras y aspiracionales ${ }^{133}$ que contienen múltiples visiones de justicia todavía inalcanzadas, para materializarlas en un futuro no tan lejano. En ello, debe ser claro que todas las grandes cartas de la historia mundial del Estado constitucional tenían, en el momento de su promulgación, este carácter transformador y aspiracional -sea en Virginia en 1776, en Francia en 1793, en Alemania en 1919 y 1949 o en España en 1978-, pues, en vez de fijar el pasado, se adscribieron a la finalidad de establecer un país más justo. En general, la historia mundial del Estado constitucional describe un proceso permanente de retroalimentación y aprendizaje.

También en la sexta ola del Estado constitucional iberoamericano, se promulgaron contenidos normativos novedosos, por ejemplo, en cuanto al constitucionalismo ambiental y étnico, que buscaron la transformación de realidades sociales mediante el derecho en el próximo futuro. A esta dinámica perteneció que, después de pocos años, la justicia constitucional entendió las nuevas garantías como plenamente obligatorias y las impuso frente a violadores en las otras ramas estatales. Puede ser que los resultados de transformación no cumplen con las expectativas de todo constitucionalista, pero en una perspectiva a largo plazo que evalúe todas las seis fases del Estado constitucional iberoamericano en conjunto, los logros transformadores de dos siglos son impresionantes.

${ }^{133}$ García, Constitucionalismo aspiracional, pp. 89-110; Santos, Refundación del Estado, pp. 71 y ss; Uprimny, Las transformaciones constitucionales recientes, p. 123. 
Vale la pena precisar lo que significa el presumido carácter normativo y que no: primero, hay que rechazar toda posibilidad de pensar una identidad absoluta entre una fuente normativa y la realidad socio-cultural; segundo, en el mundo no existen constituciones con la habilidad de describir completamente todos los procesos reales de poder, pues el estilo acostumbrado favorece algunas manchas ciegas, por ejemplo, en cuanto a la interacción de las élites republicanas y económicas que tienden a prácticas lobbyistas; tercero, ninguna democracia representativa y electoral del planeta alcanza algo tan solemne y puro como el mito popularizado del autogobierno del pueblo; cuarto, en contra del inocentísimo popular que tiende a leer normas constitucionales de modo aislado y no de manera sistemática, se insiste en que ningún elemento parcial del triángulo de valores liberales, sociales y ambientales puede leerse de modo desconectado, sino solo en un marco integral que permite ponderaciones diversificadas de las tensiones inmanentes, donde la política parlamentaria tiene potestades discrecionales de precisión e inactividad, aunque estos no son ilimitados en términos jurídicos, pues no pueden violar la garantía nuclear de todo valor constitucional; quinto, algunos elementos que el texto constitucional mencione de modo breve en lugares poco prominentes, pueden alcanzar un significado sobresaliente; sexto, en todo Estado constitucional de la Tierra hay que lamentar una multitud de transgresiones en las zonas fronterizas de los derechos fundamentales que están bien documentados en las colecciones de sentencias de las altas cortes de justicia. En todo esto, América Latina no se diferencia sustancialmente de los otros países de la cultura llamada occidental, sino solo gradual y difusamente.

Otra pregunta comparativa es si los sistemas parlamentarios de Europa no se han alejado en mayor medida del carácter normativo de la constitución, teniendo en cuenta que las respectivas cartas repiten estereotípicamente el homenaje al principio de la separación de poderes, mientras la realidad política está marcada por la identidad entre la mayoría parlamentaria y el 
gobierno, es decir, la verdadera separación existe entre la fracción de gobierno y aquella de la oposición. Tampoco pueden considerarse una manifestación de la sinceridad y transparencia las constituciones de las monarquías liberales del norte europeo, donde los textos tienden a conservar la estructura más autocrática del siglo XIX, mientras la realidad política corresponde a la de democracias sociales modernas.

En cambio, con respecto a los derechos de segunda y tercera generación, puede aludirse que la eficacia y calidad del constitucionalismo social ha alcanzado más realidad en Europa occidental que en América Latina, mientras una hipótesis análoga no sería del mismo modo cierto para el constitucionalismo ambiental, pues la calidad ambiental se presenta superior en varios países latinoamericanos debido a menores excesos del consumismo industrial.

Con base en estas reflexiones, las diferencias intercontinentales entre los textos constitucionales del nuevo y viejo mundo, parecen más estilísticas y menos materiales, en el sentido de que al sabor latinoamericano le gusta la formulación solemne de textos representativos y románticos, lo que puede asociarse posiblemente con algún grado de preferencia cultural por la poesía y el culto a la belleza, pero nada de esto significa una connotación fraudulenta y no hay ningún indicio de que el estilo más frio de otros países, llevaría por sí mismo a una calidad superior. Más bien, la visión iberoamericana contiene una interiorización amplia del carácter iusnatural intocable del constitucionalismo liberal, social y ambiental, es decir, una enorme fuerza que prepara sosteniblemente para sobrevivir crisis difíciles.

No obstante, para la historia constitucional más reciente hay que señalar por los menos cinco contextos de deficiencias mayores: primero, se indica el desastroso balance de derechos humanos en las zonas del conflicto y posconflicto armado interno de Colombia, incluyendo la paramilitarización de los años 90 hasta por lo menos 2005, los bombardeos militares de civiles y las ejecuciones extralegales de los llamados falsos positivos, lo que encuentra su prolongación en la no protección 
de líderes sociales asesinados sistemáticamente; segundo, se apunta cuatro golpes de Estado blandos o postmodernos que llevaron a la pérdida involuntaria de la Presidencia, sin respetar el régimen constitucional de sucesión: en Honduras en 2009, en Paraguay en 2012, en Brasil en 2016 y en Bolivia en 2019; tercero, se anotan las tendencias neo-autocráticas en Venezuela desde hace por lo menos 2017 y el neo-estadositismo chileno y boliviano desde 2019; cuarto, con la excepción del Cono sur, se señala un fuerte problema de gobernabilidad, relacionado con la eficiencia limitada en cumplir con diversas tareas básicas de la estatalidad, la cual se disminuye, a veces, hacia una especie de Leviatán de peluche, no solo en Colombia con su erosión institucional debido al largo conflicto armado interno, sino en todo el semi-círculo alrededor del mar Caribe que se extiende de México, pasando por Centroamérica y Colombia hasta Venezuela; quinto, desde el 2017, al estilo de un reflejo de percepciones de deficiencias múltiples, se observa una acentuada ola transnacional de masivas protestas sociales.

\section{Bibliografía}

\section{a. Fuentes primarias}

aa. Constituciones y reformas

(1979) Constitución para la República del Perú, ed. por Congreso del Perú, http://www.leyes.congreso.gob.pe/Documentos/ constituciones_ordenado/CONSTIT_1979/Cons1979_TEXTO_ CORREGIDO.pdf (5.1.2020).

(1980) Constitución política de la República de Chile, Decreto ley 3.464, en Diario Oficial, de 11.8.1980.

(1983) Constitución de El Salvador, ed. por Asamblea Legislativa de El Salvador, http://www.asamblea.gob.sv/eparlamento/indicelegislativo/buscador-de-documentos-legislativos/constitucionde-la-republica (5.1.2020).

(1985) Constitución política de la República de Guatemala, ed. por Bibl. Virtual Cervantes, http://www.cervantesvirtual. com/ nd/ark:/59851/bmcw10z2 (5.1.2020). 
(1988) Constituição da República federativa do Brasil, ed. por Presidência da República, http://www.planalto.gov.br/ccivil_03/Constituicao/Constituicao.htm (5.1.2020).

(1989) Ley chilena 18.825 de reforma constitucional, en Diario Oficial, de 17.8.1989.

Ley costarricense 7.128 por la que se reforman los arts. 10, 48, 105 y 128 de la CP, en La Gaceta, 166, de 1.9.1989.

(1990) Reformas constitucionales por decreto en orden cronológico, ed. por Cámara de Diputados de México, http://www.diputados.gob.mx/LeyesBiblio/ref/cpeum_crono.htm (5.1.2020).

(1991) Constitución política de la República de Colombia, en Gaceta Constitucional, 127, de 10.10.1991.

(1992) Constitución de la República de Paraguay, ed. por Dippel, Horst (Ed.): Constitutions of the World, 1850 to the Present, II, Múnich, K.G. Saur, 2005, índice interino 8, microficha 1.126, 1-25.

Decreto por el que se reforma el artículo $4^{\circ}$ de la Constitución politica de los Estados Unidos Mexicanos, en Diario Oficial de la Federación, de 28.1.1992.

(1993) Constitución política del Perú, en El Peruano, Diario Oficial, ed. especial, de 30.12.1993.

(1994) Constitución de la Nación Argentina (sancionada en 1853, con las reformas de los años 1860, 1866, 1898, 1957 y 1994), en Boletín Oficial, de 23.8.1994, y Buenos Aires, Impr. del Congreso de la Nación, 1994.

Constitución de la República Dominicana, en Gaceta Oficial, 9.890, de 20.8.1994.

Constitución política de la República de Panamá de 1972 con reformas de 1978, 1983 y 1994, ed. por Bibl. Nacional Castillero R., bttp://binal.ac.pa/binal/component/content/article/78servicios/147-constituciones-art.html (5.1.2020).

(1995) Constitución politica del Estado de Bolivia, ley 1.615 (= Constitución de 1967 con ley de reforma 1.585 de 1994), ed. por portal jurídico Lex i Vox libre, https://www.lexivox.org/norms/ BO-L-1615.html (5.1.2020).

(1996) Ley peruana 26.657 de interpretación auténtica del art. 112 de la Constitución, en El Peruano, Diario Oficial. 
(1998) Constitución política de la República del Ecuador, Decreto legislativo OOO, en Registro Oficial, 1, de 11.8.1998.

(1999) Constitución de la República bolivariana de Venezuela, en Gaceta Oficial, 36.860, de 30.12.1999.

(2000) Ley peruana 27.365 de reforma constitucional que elimina la reelección presidencial inmediata, en El Peruano, Diario Oficial, 7.440, de 5.11.2000.

(2001) Decreto por el que se aprueba el diverso por el que se adicionan un $2^{\circ} y 3^{\text {er }}$ párrafos al art. $1^{\circ}$, se reforma el art. $2^{\circ}$, se deroga el $\S 1^{\circ}$ del art. $4^{\circ}$; y se adicionan un $6^{\circ} \S$ al art. 18 , y un último $\S$ a la fracción $3^{\mathrm{a}}$ del art. 115 de la $\mathrm{CP}$ de los EU Mexicanos, en Diario Oficial, de 14.8.2001.

(2004) Constitución de la República Oriental del Uruguay de 1967 con las modificaciones plebiscitadas en 1989, 1994, 1996 y 2004, ed. por Poder Legislativo del Uruguay, https://legislativo. parlamento.gub.uy/ temporales/1409664.HTML (5.1.2020).

(2005) Decreto por el que se declara reformados los arts. $14,2^{\circ} \S y$ $221^{\text {er }}$, y derogado el $4^{\mathrm{o}} \S$ del art. 22 de la CP de los Estados Unidos Mexicanos, en Diario Oficial, de 9.12. 2005.

Ley chilena 20.050, Reforma constitucional, en Diario Oficial, de 26.8.2005.

(2008) Constitución de la República del Ecuador, en Registro Oficial, 449, de 20.10. 2008.

(2009) Constitución politica del Estado plurinacional de Bolivia, ed. por Infoleyes Bolivia, https://bolivia.infoleyes.com/ norma/469/constituci \%C3 \%B3n-pol \%C3 \%ADtica-delestado-cpe (5.1.2020).

(2009) Enmienda 1 a la Constitución de la República bolivariana de Venezuela de 1999, en Gaceta Oficial, de 19.2.2009.

(2014) Ley 854 de la reforma parcial de la Constitución política de la República de Nicaragua, en La Gaceta, separata, de 10.2.2014.

(2015) Acto legislativo colombiano 2 por medio del cual se adopta una reforma de equilibrio de poderes y reajuste institucional, en Diario Oficial, 49.560, de 1.7.2015. 
bb. Leyes y decretos

(1978) Decreto ley chileno 2.191, concede amnistía, en Diario Oficial, de 19.4.1978.

(1983) Ley argentina 22.924 de pacificación nacional, en Boletín Oficial, de 29.9.1983.

Ley argentina 23.040 que anula la autoamnistía, en Boletín Oficial, de 29.12.1983.

(1984) Ley argentina 23.077 de defensa de la democracia, en Boletín Oficial, de 27.8.1984.

(1986) Ley uruguaya 15.848 de la caducidad de la pretensión punitiva del Estado, en Diario Oficial, 22.295, de 28.12.1986.

(1992) Decreto ley peruano 25.418, Bases del Gobierno de Emergencia, en El Peruano, Diario Oficial, de 9.4.1992.

(1993) Ley colombiana 104 de orden público, en Diario Oficial, 41.158, de 30.12.1993.

(1997) Ley boliviana 1.768 de modificaciones al Código penal, en Gaceta Oficial, 1984, de 10.3.1997.

(1998) Ley boliviana 1.836 del Tribunal Constitucional de 1998, en Gaceta Oficial, de 19.3.1998.

(2000) Resolución legislativa del Congreso peruano 009-2000-CR declarando la permanente incapacidad moral del presidente de la república y la vacancia, http://www4.congreso.gob.pe/ museo/mensajes/A-Mensaje-2000-5.pdf (6.4.2016).

(2001) Ley peruana 27.600 que suprime firma y establece proceso de reforma constitucional, en El Peruano, Diario Oficial, de 16.12.2001.

(2005) Ley colombiana de justicia y paz, Ley 975, en Diario Oficial, 45.980, de 25.7.2005.

Ley guatemalteco marco de los acuerdos de paz, Decreto 52, en Diario de Centro América, 56, de 7.9.1985.

(2011) Ley peruana 29.785 del derecho a la consulta previa a los pueblos indígenas, en El Peruano, Diario Oficial, de 7.9.2011.

cc. Acuerdos de paz

(1992) Acuerdos de Chapultepec entre el Gobierno de El Salvador y el Frente Farabundo Martí para la Liberación Nacional. 
(2016) Acuerdo final para la terminación del conflicto y la construcción de una paz estable y duradera de 24.11.2016.

dd. Jurisprudencia

Argentina, Cámara Nacional Argentina de Apelaciones en lo Criminal y Correccional Federal de la Ciudad de Buenos Aires

(1985) Juicio a las Juntas, causa 13/84, sent. de 9.12.1985.

Bolivia, Corte Suprema de Justicia de la Nación

(1993) Sentencia pronunciada en los juicios de responsabilidad seguidos por el Ministerio Publico y coadyuvantes contra Luis García M. y sus colaboradores, de 21.4.1993.

Bolivia, Tribunal Constitucional Plurinacional

(2013) Consulta sobre la constitucionalidad del proyecto Ley de Aplicación Normativa, Declaración constitucional plurinacional, sentencia 003, exp. 02856-2013-06-CCP, de 25.4.2013, MR Zenón H. Bacarreza M.

(2017) Repostulación de Morales, sentencia 0084/2017, exp. 209602017-42-AIA, de 28.11.2017, MR Macario L. Cortez Ch.

Colombia, Consejo de Estado, Sala de lo Contencioso Administrativo, Sección Primera

(2014) Protección de derechos colectivos de los habitantes de la cuenca bidrográfica del río Bogotá, exp. AP-25000-23-27-0002001-90479-01, sent. de 28.3.2014, CP Marco A. Velilla M.

Colombia, Corte Constitucional

(1992) T-426/92, Derecho a la subsistencia, MP Eduardo Cifuentes M. T-528/92, Contaminación ambiental, derecho a la vida y a un medio ambiente sano, MP Fabio Morón D.

T-536/92, Derecho al ambiente sano, MP Simón Rodríguez R.

(1993) C-027/93, Demandas acumuladas, Ley 20 de 1974 por la cual se aprueba el Concordato, MP Simón Rodríguez R.

(1994) T-254/94, Comunidad indígena, MP Eduardo Cifuentes M.

(1995) C-466/95, Conmoción interior, MP Carlos Gaviria D.

T-015/95, Salarios de personas secuestradas, MP Hernando Herrera V.

(1997) C-239/97, Homicidio por piedad, MP Carlos Gaviria D.

C-358/97, Código penal militar, MP Eduardo Cifuentes M.

(1998) C-087/98, Ley 51 de 1975, MP Carlos Gaviria D. 
(2000) C-392/00, Juzgado especializado, MP Antonio Barrera C.

(2002) C-802/02, Control de constitucionalidad de decreto declaratorio de conmoción interior, MP Jaime Córdoba T.

(2003) C-327/03, Control de constitucionalidad, DL 245 por el cual se prorroga el Estado de conmoción interior, MP Alfredo Beltrán S.

(2004) C-816/04, Demanda de inconstitucionalidad, Acto legislativo 2 de 2003 para enfrentar el terrorismo, MPs Jaime Córdoba T. \& Rodrigo Uprimny Y.

T-025/04, Población desplazada, 2004, MP Manuel J. Cepeda.

(2006) C-355/06, Aborto, MPs Jaime Araújo R. \& Clara Inés Vargas H.

(2010) C-141/10, Constitucionalidad de la Ley 1.354 de 2009, convocatoria a un referendo nacional, MP Humberto A. Sierra P.

C-703/10, Constitución ecológica, medio ambiente, MP Gabriel E. Mendoza M.

(2016) T-622/16, Río Atrato como sujeto de derechos, MP Jorge I. Palacio P.

(2018) SU-123/18, Comunidades indígenas, MPs Alberto Rojas R. \& Rodrigo Uprimny Y.

Colombia, Corte Suprema, Sala Plena

(1987) Sentencia 20, inconstitucional el Decreto 3.671 de 1986, de 5.3.1987, MP Jesús Vallejo M.

(1989) Sentencia 022, inexequible el \$ 3 del artículo 33 del Decreto 3.398 de 1965, de 25.5.1989.

Colombia, Jurisdicción Especial para la Paz

(2018) JEP abre el caso 003 'Muertes ilegítimamente presentadas como bajas en combate por agentes del Estado', comunicado 58, de 23.7.2018.

(2019) JEP abre el caso 06, Victimización de miembros de la Unión Patriótica (UP), de 4.3.2019.

Guatemala, Corte de Constitucionalidad

(1993) Normas temporales de gobierno, exp. 225-93, de 25.5.1993.

(2013) Caso Ríos Montt, exp. 1904-2013, de 20.5.2013.

Interamericana, Corte de Derechos Humanos

(2001) Caso del Tribunal Constitucional vs. Perú, sent. de 31.1.2001, FRC, serie C, 71. 
(2001) Caso Barrios Altos vs. Perú, sent. de 14.3.2001, FRC, serie C, 75 .

(2002) Caso del Caracazo vs. Venezuela, sent. de 29.8.2002, FRC, serie C, 95.

(2004) Caso 19 comerciantes vs. Colombia, sent. de 5.7.2004, FRC, serie C, 109.

(2010) Caso Manuel Cepeda V. vs. Colombia (caso UP), sent. de 26.5.2010, FRC, serie C, 213.

(2018) Caso Villamizar D. y otros vs. Colombia, sent. de 20.11.2018, FRC, serie C, 364 .

Internacional, Corte de Justicia

(1986) Military and Paramilitary Activities in and against Nicaragua (Nicaragua v. US of America), Jurisdiction and Admissibility, 1984 ICJ REP. 392, de 27.6.1986.

Nicaragua, Corte Suprema de Justicia, Sala de lo Constitucional

(2009) Reelección de presidente y alcaldes, sent. 504, exp. 602-09, de 19.10.2009.

Perú, Corte Suprema de Justicia del Perú, Sala Penal Especial

(2009) Casos Barrios Altos, La Cantuta y Sótanos SIE (Causa Fujimori), exp. A.V. 19-2001, sent. de 7.4.2009.

Perú, Tribunal Constitucional

(1997) Interpretación del art. 112 de la Constitución sobre reelección presidencial, exp. 002-96-I/TC, sent. de 3.1.1997.

(2003) Marcelino Tineo Silva y más de 5.000 ciudadanos contra los Decretos Leyes 25.475, 25.659, 25.708 y 25.880, exp. 0102002-AI/TC, sent. de 3.1.2003.

(2006) Complejo metalúrgico de La Oroya, exp. 2002-2006-PC/ TC, sent. de 12.5.2006.

Uruguay, Juzgado penal de Montevideo

(2009) del $19^{\circ}$ turno: Gregorio Álvarez et al., Reiterados delitos de homicidio muy especialmente agravados, sent. 0157, de 21.10.2009.

(2010) del 23\% $7^{\circ}$ turno: Bordaberry Arocena, Juan María, Diez delitos de homicidio muy especialmente agravados, sent. de 9.2.2010. 
ee. Reportes de comisiones de verdad

Centro Nacional de Memoria Histórica (Ed.): Todo pasó frente a nuestros ojos, El genocidio de la Unión Patriótica 1984-2002, Bogotá, CNMH, 2018.

Comisión de la Verdad para El Salvador: De la locura a la esperanza, La guerra de 12 años en El Salvador, 1993.

Comisión de la Verdad y Reconciliación del Perú: Informe final, Lima, 2003.

Comisión Nacional de Argentina sobre la Desaparición de Personas: Nunca más, Never again, A Report by Argentina's National Commission on Disappeared People, Londres, Faber, 1986.

Comisión para el Esclarecimiento Histórico: Guatemala, Memoria del silencio (completo), Guatemala, Oficina de Servicios para Proyectos de las Naciones Unidas, 1999.

\section{b. Bibliografía secundaria}

Acosta, Albero: "Derechos de la naturaleza y buen vivir", en revista Pensamiento Jurídico, $\mathrm{n}^{\circ}$ 25, Bogotá, UNAL, 2009, pp. 21-28.

Ahrens, Helen: "La transformación de la juridicidad en los Estados latinoamericanos", en Íd. (Ed.): El Estado de derecho boy en América Latina, Berlín \& México, KAS \& GIZ, 2012, pp. 137154.

Albó, Xavier et al.: Atlas sociolingüístico de América Latina, tomo 1, Casilla \& Cochabamba, UNICEF, 2009.

Alvaredo, Facundo et al.: World Inequality Report 2018, sin lugar, Inequality Lab, 2018.

Anderson, Perry et al.: Golpe en Brasil, Genealogía de una farsa, Buenos Aires, Clacso, 2016.

Arango R., Rodolfo: El concepto de derechos sociales fundamentales, $2^{\text {a }}$ ed., Bogotá, Legis, 2012.

- "La justiciabilidad de los derechos sociales fundamentales en Colombia”, en Bogdandy, Armin v.et al. (Eds.): Construcción y papel de los derechos sociales fundamentales, México, UNAM, 2011, pp. 17-34.

Arenas F., J. Francisco: "De la participación ciudadana y el activismo judicial, Intervenciones del juez constitucional en las políticas 
públicas”, en Marquardt, Bernd (Ed.): Constitucionalismo científico, Bogotá, Temis, 2012, 149-170.

Ariza S., Rosembert: Coordinación entre sistemas jurídicos y administración de justicia indígena en Colombia, San José, IIDH, 2010.

Arteaga, Juan J.: Breve historia contemporánea del Uruguay, Buenos Aires, FCE, 2008.

Barros, Robert: Constitutionalism and dictatorship, Pinochet, the Junta, and the 1980 Constitution, Cambridge, Univ. Press, 2002.

Bernal P., Carlos: El neoconstitucionalismo y la normatividad del derecho, Bogotá, Univ. Externado, 2009.

Bernales B., Enrique: "Los caminos de la reforma constitucional en el Perú", en Anuario de Derecho Constitucional Latinoamericano, $\mathrm{n}^{\circ}$ 1, Montevideo, KAS, 2005, pp. 157-173.

Binder, Christina: "Auf dem Weg zum lateinamerikanischen Verfassungsgericht?" en revista Zeitschrift für ausländisches öffentliches Recht und Völkerrecht, $\mathrm{n}^{\circ}$ 71, Heidelberg, MPI aöRV, 2011, pp. 1-29.

Bogdandy, Armin v.: "Ius Constitutionale Commune Latinoamericanum, Una aclaración conceptual", en Íd. et al. (Eds.): Ius Constitutionale Commune en derechos humanos en América Latina, México, Porrúa, 2013, pp. 1-24.

— \& Venzke, Ingo: ¿En nombre de quién? Una teoría de derecho público sobre la actividad judicial internacional, Bogotá, Univ. Externado, 2016.

Bos, Ellen: Verfassungsgebung und Systemwechsel, Wiesbaden, VS Vlg., 2004.

Bosch, Mariano et al.: Mejores pensiones, mejores trabajos, Washington, BID, 2013.

Brewer C., Allan R.: Historia constitucional de Venezuela, 2 tomos, Caracas, Ed. Alfa, 2008.

- "Reflexiones críticas sobre la Constitución de Venezuela de 1999”, en Valadés, Diego \& Carbonell, Miguel (Eds.): Constitucionalismo iberoamericano del siglo XXI, $2^{\text {a }}$ ed., México, UNAM, 2004, pp. 171-193.

- "Reflexiones sobre la dictadura en Venezuela", en Revista de Derecho Público, no 153-154, Caracas, Jurídica, 2018, pp. 177-216. 
Burgos S., Germán: Estado de Derecho y globalización, Bogotá, UNAL \& ILSA, 2009.

Calle M., Melba L.: Constitución y guerra, Bogotá, Ibáñez, 2014.

Cantón, Santiago: "Leyes de amnistía", en Reátegui, Félix (Ed.): Justicia transicional, Brasilia, Comisión de Amnistía del Min. de Justicia, 2011, pp. 265-291.

Carazo O., Pía: "El Sistema Interamericana de Derechos Humanos", en Bogdandy, Armin v. et al. (Eds.): ¿Integración suramericana a través del Derecho? Heidelberg \& Madrid, MPI aöRV \& CEPC, 2009, pp. 231-286.

Carbonell, Miguel (Ed.): Neoconstitucionalismo(s), $4^{\mathrm{a}}$ ed., Madrid, Trotta, 2009.

- (Ed.): Teoria del neoconstitucionalismo, Ensayos escogidos, Madrid, Trotta, 2007.

Carreras, Sandra \& Potthast, Barbara: Eine kleine Geschichte Argentiniens, Fráncfort, Suhrkamp, 2010.

Casal H., Jesús M.: "El constitucionalismo latinoamericano y la oleada de reformas constitucionales en la región andina", en revista Rechtsgeschichte, $\mathrm{n}^{\circ}$ 16, Fráncfort, Klostermann, 2010, pp. 212-241.

Castro H., Carlos E.: Salud y seguridad social, Bogotá, FES, 2012.

Colectivo de Abogados José Alvear R., Diez verdades sobre Carbones de Cerrejón, Cajar, 2019, https: //www.colectivodeabogados.org/IMG/pdf/diez_verdades_sobre_carbones_de_cerrejon. $p d f(5.1 .2020)$.

Couso, Javier et al.: Constitutional Law in Chile, Alphen, Wolters Kluwer, 2011.

Cristi B., Renato \& Ruiz-T., Pablo: La república en Chile, Santiago, Lom, 2006.

Cumplido C., Francisco: "Reforma constitucional en Chile", en Anuario de Derecho Constitucional Latinoamericano, $\mathrm{n}^{\circ} 1$, Berlín \& Montevideo, KAS, 2006, pp. 105-113.

Cunha, Paulo F. da: "Do constitucionalismo brasileiro", en revista Historia Constitucional, $\mathrm{n}^{\circ}$ 8, Madrid \& Oviedo, CEPC \& Univ. de Oviedo, 2007, pp. 263-271.

Defensoría del Pueblo (Ed.): La tutela y los derechos a la salud y a la seguridad social 2018, Bogotá, Defensoría del Pueblo, 2019. 
Delgado R., Camilo A.: Políticas públicas, juez constitucional y derechos sociales, Bogotá, Ibáñez, 2018.

Díaz L., Claudio H. et al.: "Formación docente en Chile", en revista Civilizar, vol. 15, n 28, Bogotá, Univ. Sergio Arboleda, 2015, pp. 229-246.

Dinerstein, Ana C.: "Impeachment or 'Soft Coup'?” en DevLog@ Bath, de 19.5.2016, https://cdsblogs.wordpress.com/(5.1.2020).

Duarte H., Natally et al.: "La implementación del Acuerdo final de paz (Meta)", en Marquardt, Bernd et al. (Eds.): Paz territorial y paz pedagógica en Colombia, Bogotá \& Göttingen, Ibáñez \& UNAL \& Univ. Göttingen, 2019, pp. 247-299.

Duque, Iván et al.: Bases del Plan Nacional de Desarrollo, 20182022, Bogotá, DNP, 2019.

Echeverri U., Álvaro \& Duque A., Corina: Política y constitucionalismo en Suramérica, Bogotá, Ibáñez, 2015.

FAO et al.: Panorama de la seguridad alimentaria y nutricional en América Latina y el Caribe 2018, Santiago de Chile, FAO, 2018.

Feoli, Marco: "Las cortes super poderosas" en revista Pensamiento Jurídico, $\mathrm{n}^{\circ}$ 41, Bogotá, UNAL, 2015, pp. 127-162.

Ferrajoli, Luigi: Garantismo, Una discusión sobre derecho y democracia, Madrid, Trotta, 2006.

Ferreyra, R. Gustavo: Fundamentos constitucionales, $2^{\mathrm{a}}$ ed., Buenos Aires, Ediar, 2015.

- Notas sobre derecho constitucional y garantías, $2^{\mathrm{a}}$ ed., Buenos Aires, Ediar, 2016.

Ganser, Daniele: Illegale Kriege, Zürich, Orell Füssli, 2016.

García B., Domingo: "Sobre la problemática constitucional en el Perú de hoy”, en Valadés, Diego \& Carbonell, Miguel (Eds.): Constitucionalismo iberoamericano del siglo XXI, $2^{\text {a }}$ ed., México, UNAM, 2004, pp. 195-209.

García C., Diego: Caso Oxy, Defensa jurídica de una decisión soberana y en derecho del Estado ecuatoriano, Quito, Procuraduría, 2014.

García L., Jorge M.: Constituciones iberoamericanas, Guatemala, México, UNAM, 2006.

García V., Mauricio: "Constitucionalismo aspiracional", en revista Análisis Político, vol. 25, n 75, Bogotá, UNAL, 2012, pp. 89-110. 
— \& Quiroz L., Laura: "Apartheid educativo", en Revista de Economía Institucional, vol. 13, $\mathrm{n}^{\circ} 25$, Bogotá, Univ. Externado, 2011, pp. 137-162.

Gargarella, Roberto: La sala de máquinas de la Constitución, Dos siglos de constitucionalismo en América Latina (1810-2010), Buenos Aires, Katz, 2014.

- Teoría y crítica del derecho constitucional, 2 tomos, Buenos Aires, Abeledo Perrot, 2010.

Góngora M., Manuel E.: "La difusión del bloque de constitucionalidad en la jurisprudencia latinoamericana", en Bogdandy, Armin v. et al. (Eds.): Ius constitutionale commune en derechos humanos en América Latina, México, Porrúa, 2013, pp. 145-180.

González J., Jorge: "El autoritarismo latinoamericano en la 'era democrática'”, en revista Precedente, vol. 6, Cali, Univ. Icesi, 2015, pp. 9-31.

Grijalva J., Agustín: Constitucionalismo en Ecuador, Quito, Corte Constitucional, 2012.

Gros E., Héctor \& Esteva G., Eduardo G.: Constituciones iberoamericanas, Uruguay, México, UNAM, 2005.

Gudynas, Eduardo: "Politische Ökologie", en revista Juridikum, $\mathrm{n}^{\circ} 4$, Viena, Vlg. Österreich, 2009, pp. 214-218.

Heritage Foundation (Ed.): 2019 Index of Economic Freedom, https://www.heritage.org/index/explore?view=by-variables $\varepsilon u=636853125789029217$ (5.1.2020).

Huertas D., Omar \& Cáceres T., Víctor M.: "Los golpes de Estado constitucionales en Latinoamérica", en revista Justicia Juris, vol. 10, $\mathrm{n}^{\circ}$ 2, Barranquilla, Univ. Autónoma, 2014, pp. 28-35.

Jaramillo F., Verónica: "Violaciones a los derechos humanos en el conflicto armado", en Revista Derechos Humanos, vol. 2, no 4, Buenos Aires, Min. de Justicia y Derechos Humanos, 2014, pp. 201-216.

Jaramillo P., Juan F.: Constitución, democracia y derechos, Bogotá, Dejusticia, 2016.

Jost, Stefan: Bolivien, Politisches System und Reformprozess 19931997, Opladen, Leske \& Budrich, 2003.

Kada, Naoko: "Impeachment as a Punishment for Corruption? The Cases of Brazil and Venezuela", en Íd. \& Baumgartner, Jody C. 
(Eds.): Checking Executive Power, Westport, Greenwood, 2003, pp. 113-136.

Kuppe, René: Indigene Rechtsprechung und staatliches Recht in Lateinamerika, Eschborn, GTZ \& Univ. Wien, 2010.

Kurtenbach, Sabine: "Venezuela, Wahlen allein reichen nicht", en revista GIGA Focus Lateinamerika, $\mathrm{n}^{\circ}$ 1, Hamburgo, GIGA, 2019, pp. 1-13.

Landa, Cesar: "Los derechos fundamentales como límites a la legislación antiterrorista", en García B., Domingo (Ed.): La Constitución y su defensa, Lima, IIDC, 2003, pp. 103-129.

Landau, David: "Abusive Constitutionalism", en UC Davis Law Review, vol. 47, Davis, Univ. of California, 2013, pp. 189-260.

- "Los derechos socioeconómicos sin transformación social en América Latina”, en Bonilla M., Daniel (Ed.): El constitucionalismo en el continente americano, Bogotá, Siglo d. Hombre, 2016, pp. 265-304.

Laughland, John: A History of Political Trials, Oxfordshire, Peter Lang, 2008.

Llanos Mariana, \& Tibi W., Cordula: "Die Justiz in Lateinamerika, Zwischen Unabhängigkeit und Kontrolle", en revista GIGA Focus Lateinamerika, $\mathrm{n}^{\circ}$ 9, Hamburgo, GIGA, 2013, pp. 1-8.

Llinás A., David E.: Constitución y ética constitucional, Bogotá, Ibáñez, 2019.

- “Derecho público multinacional y anti-constitucional? Las reformas estructurales del Consenso de Washington y el derecho social en Brasil, Venezuela, Argentina y Colombia", en Marquardt, Bernd (Ed.): El Estado constitucional de los valores, Anuario V de CC - Constitucionalismo Comparado, Bogotá, Ibáñez, 2015, pp. 185-264.

- "Los derechos sociales en el Estado constitucional democrático, social y ambiental, Algunas problemáticas para su revisión en clave socio-cultural", en Marquardt, Bernd et al. (Eds.): Querétaro 1917 \& Weimar 1919, El centenario del constitucionalismo de la democracia social, Anuario VIII de CC - Constitucionalismo Comparado, Bogotá, Ed. Ibáñez, 2019, pp. 481-532.

Loewenstein, Karl: Verfassungslebre, $4^{\mathrm{a}}$ ed., Tübingen, Mohr Siebeck, 2000. Trad.: Teoría de la constitución, Barcelona, Ariel, 1986. 
López D., Germán A.: "Constitucionalización y protección judicial de los derechos sociales, Una aproximación al caso latinoamericano", en revista Piélagus, vol. 9, Neiva, Univ. Surcolombiana, 2010, pp. 27-41.

- La justicia constitucional colombiana, ¿Un gobierno de los jueces? Neiva, Univ. Surcolombiana, 2005.

López H., Claudia et al.: Y refundaron la patria..., De como mafiosos y políticos reconfiguraron el Estado colombiano, $13^{\mathrm{a}}$ reimpr., Bogotá, Debate, 2015.

Lorenzo, Celso R.: Manual de historia constitucional argentina, tomo 3, Rosario, Juris, 1999.

Lösing, Norbert: Die Verfassungsgerichtsbarkeit in Lateinamerika, Baden Baden, Nomos, 2001.

Mähler, Annegret: "Wie autoritär ist Lateinamerika?" en revista GIGA Focus Lateinamerika, $\mathrm{n}^{\circ}$ 8, Hamburgo, GIGA, 2008, pp. 1-8.

Marquardt, Bernd: "El anti-constitucionalismo en la historia política de Colombia (1949-1990)", en Íd. (Ed.): Constitucionalismo científico (Anuario II de CC - Constitucionalismo Comparado), Bogotá, Temis, 2012, pp. 3-43.

- Historia constitucional comparada de Iberoamérica, Las seis fases desde la revolución de 1810 hasta la transnacionalización del siglo XXI, Bogotá, Ibáñez, 2016.

- Historia del derecho de Hispanoamérica en perspectiva transnacional y socio-cultural, tomo 1, Los métodos \& la Modernidad Temprana, Los Virreinatos de la Monarquía española, 1519-1825, Bogotá, Ibáñez, 2019.

- "La Constitución de Weimar de 1919, El centenario de una estrella del constitucionalismo comparado y carta materna del constitucionalismo social-liberal", en Íd. et al. (Eds.): Querétaro 1917 \& Weimar 1919, El centenario del constitucionalismo de la democracia social, Anuario VIII de CC - Constitucionalismo Comparado, Bogotá, Ibáñez, 2019, pp. 45-164.

- "La paz territorial como paz judicial y justicia social", en Íd. et al. (Eds.): Paz territorial y paz pedagógica en Colombia, Bogotá \& Göttingen, Ibáñez \& UNAL \& Univ. Göttingen, 2019, pp. 17-104.

- Teoría integral del Estado, Pasado, presente y futuro en perspectiva mundial, tomo 2, El Estado de la doble revolución 
ilustrada e industrial (1776-2050), La gran transformación al Estado constitucional, democrático, social y ambiental, Bogotá, Ibáñez, 2018.

Mejía Q., Óscar et al.: Teoría critica de los medios de comunicación, Bogotá, UNAL, 2009.

— \& Múnera R., Leopoldo: "Constitución, democracia y Estado autoritario en Colombia", en revista Ciencia Política, $\mathrm{n}^{\circ}$ 6, Bogotá, UNAL, 2008, pp. 80-108.

Merkel, Wolfgang: Systemtransformation, Eine Einfübrung in die Theorie und Empirie der Transformationsforschung, $2^{\mathrm{a}}$ ed., Wiesbaden, VS Vlg., 2010.

Mesa C., Gregorio: Derechos ambientales en perspectiva de integralidad, $3^{\text {a }}$ ed., Bogotá, UNAL, 2013.

Meza S., Rocio: "Judicial Enforcement and the Protection of the Right to Health and the Environment", en revista Law and Politics in Africa, Asia and Latin America, vol. 41, n 2, Hamburgo, GVAP, 2008, pp. 169-184.

Montoro i Ch., María J.: "El Estado ambiental de derecho, Bases constitucionales", en Sosa W., Francisco (Ed.): El derecho administrativo en el umbral del siglo XXI, tomo 3, Valencia, Tirant lo Blanch, 2000, pp. 3437-3466.

Morales A., Mariela: "El Estado abierto y el cambio de paradigma de la soberanía", en Bogdandy, Armin v. et al. (Eds.): Ius constitutionale commune en derechos humanos en América Latina, México, Porrúa, 2013, pp. 65-144.

- Protección supranacional de la democracia en Suramérica, México, UNAM, 2015.

Morales V., Andrés: "Derechos fundamentales y democracia en la filosofía del derecho de L. Ferrajoli", en Marquardt, Bernd (Ed.): Constitucionalismo comparado, Bogotá, UNAL, 2009, pp. 483-512.

Naciones Unidas, Consejo de Derechos Humanos (Ed.): Informe analítico sobre la objeción de conciencia al servicio militar, 2013.

Naranjo M., Vladimiro: Teoría constitucional e instituciones políticas, 12 $2^{\mathrm{a}}$ ed., Bogotá, Temis, 2014.

Negretto, Gabriel L.: Making Constitutions, Cambridge, Univ. Press, 2013. 
Nogueira A., Humberto: "Decreto ley de amnistía 2.191 de 1978 y su armonización con el derecho internacional de los derechos humano", en Revista de Derecho, vol. 18, n 2, Valdivia, Univ. Austral, 2005, pp. 107-130.

- "La defensa de la Constitución, los modelos de control de constitucionalidad y las relaciones y tensiones de la judicatura ordinaria y los tribunales constitucionales en América del Sur", en revista Contribuciones, vol. 3, Buenos Aires, KAS, 2002, pp. 153-230.

Nolte, Detlef: "Regionale politische Sonderentwicklungen", en BPB (Ed.): Lateinamerika II, Bonn, BPB, 1994, pp. 31-34.

- "Verfassungsreformen und Verfassungskrise in Honduras in vergleichender Perspektive", en revista Law and Politics in Africa, Asia and Latin America, vol. 43, $\mathrm{n}^{\circ}$ 1, Hamburgo, GVAP, 2010, pp. 28-45.

- "Verfassungspopulismus und Verfassungswandel in Lateinamerika", en revista GIGA Focus Lateinamerika, n 2., Hamburgo, GIGA, 2009, pp. 1-7.

- “Zurück zur Demokratie in den 80er Jahren", en BPB (Ed.): Lateinamerika II, Bonn, BPB 1994, pp. 35-41.

Núñez M., Raúl F. \& Canal F., Sebastián: "Las masacres de Río Negro, Reflexiones sobre el genocidio de las comunidades indígenas y la obligación de investigar, juzgar y castigar", en revista Criterio Jurídico, vol. 12, $\mathrm{n}^{\circ} 2$, Cali, Univ. Javeriana, 2012, pp. 121-150.

Olano G., Hernán A.: Constitucionalismo histórico, Bogotá, Doctrina y Ley, 2007.

OECD (Ed.): Education at a Glance 2019, OECD Indicators, París, OECD, 2019.

- (Ed.): PISA 2018 Results, What Students know and can do, t. 1, París, OECD, 2019.

- \& BID \& Banco Mundial (Eds.): Panorama de las pensiones, América Latina y el Caribe, BID et al., 2015.

Ortega G., Gustavo A.: "Constitucionalismo ambiental y derechos ambientales", en Mesa C., Gregorio (Ed.): Derechos ambientales en disputa, Bogotá, UNAL, 2015, pp. 43-123.

Pacheco M., Luis A.: "Las penas 'salvajes' en el ejercicio de la función jurisdiccional de las comunidades nativas en el Perú", 
en revista Pensamiento Jurídico, n ${ }^{\circ}$ 22, Bogotá, UNAL, 2008, pp. 233-252.

Palacios, Marco \& Safford, Frank: Colombia, País fragmentado, sociedad divida, Su historia, Bogotá, Norma, 2002.

Pazos G., Ramiro \& Sánchez L., Guillermo (Eds.): Graves violaciones de derechos bumanos e infracciones al derecho internacional humanitario, Bogotá, Impr. Nacional, 2017.

Peetz, Peter: "Honduras, Von einem Militärputsch, der keiner sein will", en revista GIGA Focus Lateinamerika, n' 7 , Hamburgo, GIGA, 2009, pp. 1-8.

Pérez-L., Aníbal: Presidential Impeachment and the New Political Instability in Latin America, Cambridge, Univ. Press, 2007.

PNUD (Ed.): Índices e indicadores de desarrollo humano, Actualización estadística de 2018, Nueva York, PNUD, 2018.

- (Ed.): La democracia en América Latina, $2^{\mathrm{a}}$ ed., Nueva York \& Buenos Aires, Águila, 2004.

Quinche R., Manuel F.: Derecho constitucional colombiano, $4^{\mathrm{a}}$ ed., Bogotá, Doctrina y Ley, 2010.

Rabasa, Emilio Ó.: "De la democracia hegemónica o unipartidista a la democracia institucional o pluripartidista", en Valadés, Diego et al.: Hacia una nueva constitucionalidad, México, UNAM, 2000, pp. 303-312.

Red. Justicia: "Abren puerta para revisar todas las condenas de Corte contra aforados", en periódico El Tiempo, de 22.5. 2019, https://www.eltiempo.com/justicia/cortes/abren-puerta-pararevisar-todas-las-condenas-de-corte-contra-aforados-365068 (5.1.2020).

Red. Verdad Abierta: "De la curul a la cárcel", en portal VerdadAbierta.com, de 28.8.2013, https://verdadabierta.com/de-lacurul-a-la-carcel/ (5.1.2020).

Reporteros sin Fronteras: 2019 World Press Freedom Index, https:// rsf.org/en/ranking\# (5.1.2020).

Ríos V., José L.: “Tres etapas del golpe ‘blando’ en Brasil”, en Revista de Ciencias Sociales, vol. 31, $\mathrm{n}^{\circ}$ 43, Montevideo, Univ. de la Rep., 2018, pp. 183-204.

Rodríguez, Gloria A.: De la consulta previa al consentimiento libre, previo e informado a pueblos indígenas en Colombia, Bogotá, GIZ, 2014. 
Rojas B., Danilo: "Razonamiento judicial en Colombia y nuevo constitucionalismo", en Londoño U., Jorge E. (Ed.): Justicia, derecho y posconflicto, Bogotá, Ibáñez, 2016, pp. 369-402.

Rojas Y., Iván O.: "El sistema de pensiones en Bolivia", en revista Fides et Ratio, vol. 16, $\mathrm{n}^{\circ}$ 16, La Paz, Univ. La Salle, 2018, pp. 221-241.

Romero R., Eduardo: "El principio del desarrollo sostenible en Colombia", en Marquardt, Bernd (Ed.): El Estado constitucional de los valores, Anuario V de CC - Constitucionalismo Comparado, Bogotá, Ibáñez, 2015, pp. 377-428.

Romero T., Juan F.: "Constitucionalismo social en América Latina", en Marquardt, Bernd (Ed.): Constitucionalismo científico II, Entre el Estado y el mercado (Anuario III de CC - Constitucionalismo Comparado), Bogotá, Temis, 2013, pp. 69-97.

- Derecho fundamental a la salud, La Ley 1.751 de 2015, Travesía hacia un Derecho Social Fundamental, Bogotá, Ibáñez, 2019.

- "El péndulo del constitucionalismo social", en Marquardt, Bernd et al. (Eds.): Querétaro 1917 \& Weimar 1919, El centenario del constitucionalismo de la democracia social, Anuario VIII de CC - Constitucionalismo Comparado, Bogotá, Ibáñez, 2019, pp. 225-338.

- "La puerta alterna de las acciones de inconstitucionalidad", en Marquardt, Bernd (Ed.): El Estado constitucional de los valores, Anuario $V$ de CC - Constitucionalismo Comparado, Bogotá, Ibáñez, 2015, pp. 519-580.

- Las acciones públicas de inconstitucionalidad en Colombia, Bogotá, Ibáñez, 2016.

Rosales H., Eduardo A.: El juicio del siglo, Augusto Pinochet frente al derecho y la política internacional, México, Plaza y Valdés \& Univ. del Valle, 2008.

Ruiz L., Rocío: "México ¿la dictadura perfecta?" en revista Amérique Latine Histoire et Mémoire, $\mathrm{n}^{\circ}$ 38, París, Univ. Paris 8, 2019, http://journals.openedition.org/alhim/8256 (7.2.2020).

Ruíz M., Natalia: "Encuentros y desencuentros de un pluralismo jurídico en Colombia ¿es posible una sociedad pluriétnica democrática?" en Marquardt, Bernd (Ed.): El Estado constitucional en el tiempo y en el espacio, Anuario IV de 
CC - Constitucionalismo Comparado, Bogotá, UNAL, 2015, pp. 435-472.

Saffon, M. Paula \& García V., Mauricio: "Derechos sociales y activismo judicial”, en Revista estudios socio-jurídicos, vol. 13, $\mathrm{n}^{\circ}$ 1, Bogotá, Univ. del Rosario, 2011, pp. 75-107.

Sagüés, Néstor P.: Constituciones iberoamericanas, Argentina, México, UNAM, 2006.

Salazar-C., Carlos G.: "Breve historia del derecho penal colombiano", en revista Principia Iuris, vol. 13, n 26, Tunja, Univ. Santo Tomás, 2016, pp. 35-53.

Sánchez B., Esther: Justicia y pueblos indigenas de Colombia, $3^{\mathrm{a}}$ ed., Bogotá, UNAL, 2010.

Semper, Frank: Los derechos de los pueblos indígenas en Colombia, Bogotá, Temis, 2018.

Serna de la G., José M.: La reforma del Estado en América Latina, México, UNAM, 1998.

Silva, José A. da: Constituciones iberoamericanas, Brasil, México, UNAM, 2006.

Silvero S., Jorge: "Die Verfassung der Republik Paraguay von 1992", en anuario Jabrbuch des öffentlichen Rechts der Gegenwart, $N F$, tomo 46, Tübingen, Mohr Siebeck, 1998, pp. 609-670.

Sornarajah, Muthucumaraswamy: "Mutations of Neo-Liberalism in International Investment Law", en revista Trade, Law and Development, vol. 3, $\mathrm{n}^{\mathrm{o}}$ 1, Jodhpur, National Law Univ., 2011, pp. 203-232

Santos, Boaventura de S.: Refundación del Estado en América Latina, Lima, IIDS, 2010.

Suárez D., José M.: "El nuevo constitucionalismo latinoamericano", en Marquardt, Bernd (Ed.): El Estado constitucional de los valores, Anuario V de CC - Constitucionalismo Comparado, Bogotá, Ibáñez, 2015, pp. 265-336.

Thibaut, Bernhard: Präsidentialismus und Demokratie in Lateinamerika, Opladen, Leske \& Budrich, 1996.

Thiery, Peter: "Lateinamerika", en Merkel, Wolfgang (Ed.): Defekte Demokratie, Wiesbaden, VS Vlg., 2006, pp. 21-162.

Tirado S., Arantxa: Venezuela, Más allá de mentiras y mitos, Madrid, Akal, 2019. 
UN-Habitat (Ed.): Slums of the World, Nairobi, UN-Habitat, 2003.

Uprimny Y., Rodrigo: "Bloque de constitucionalidad, derechos humanos y nuevo procedimiento penal", en Dejusticia, 2017, https://cdn.dejusticia.org/wp-content/uploads/2017/04/ fi_name_recurso_47.pdf (5.1.2020).

- "La judicialización de la política en Colombia", en Palacio, Juan M. \& Candioti, Magdalena (Eds.): Justicia, politica y derechos en América Latina, Buenos Aires, Prometeo, 2007, pp. 45-63.

- "Las transformaciones constitucionales recientes en América Latina”, en Rodríguez G., César (Ed.): El derecho en América Latina, Buenos Aires, Siglo XXI, 2011, pp. 109-138.

- "The Enforcement of Social Rights by the Colombian Constitutional Court", en Gargarella, Roberto et al. (Eds.): Courts and Social Transformation in New Democracies, Aldershot, Ashgate, 2006, pp. 127-152.

Valencia Villa, Hernando: Cartas de batalla, Una crítica del constitucionalismo colombiano, $3^{\text {a }}$ ed., Bogotá, Panamericana, 2010.

Vargas L., Alan E.: "El derecho al medio ambiente en la nueva Constitución política del Estado plurinacional de Bolivia”, en Anuario de Derecho Constitucional Latinoamericano, año 18, Berlín \& Bogotá, KAS, 2012, pp. 251-270.

- "La reelección presidencial en la jurisprudencia del Tribunal Constitucional Plurinacional de Bolivia", en Anuario de Derecho Constitucional Latinoamericano, vol. 20, Berlín \& Bogotá, KAS, 2014, pp. 143-166.

Vega R., M. Luz: La reforma laboral en América Latina, 15 años después, Un análisis comparado, Lima, OIT, 2005.

Vergottini, Giuseppe de: Las transiciones constitucionales, Bogotá, Univ. Externado, 2002.

Viciano P., Roberto \& Moreno G., Gabriel: "Cuando los jueces declaran inconstitucional la constitución", en Anuario Iberoamericano de Justicia Constitucional, $\mathrm{n}^{\circ} 22$, Madrid, CEPC, 2018, pp. 165-198.

Vivas B., Tania G. \& Cubides C., Jaime A.: "Diálogo judicial transnacional en la implementación de las sentencias de la Corte Interamericana", en revista Entramado, vol. 8, n 2, Cali, Univ. Libre, 2012, pp. 184-204. 
— \& Toro B., Estefanía: "Estudio sobre el cumplimiento de la sentencia Masacre de Mapiripán contra Colombia”, en revista Prolegómenos, Derechos y Valores, vol. 19, n 37, Bogotá, Univ. Militar Nueva Granada, 2016, pp. 37-56.

Weisbrot, Mark \& Sachs, Jeffrey: Sanciones económicas como castigo colectivo, El caso de Venezuela, Washington, Center for Economic and Policy Research, 2019.

Williams O., Guidoo: Causales para decretar el estado de excepción constitucional de emergencia, Santiago, Congreso, 2019.

World Inequality Database: Top $1 \%$ National Income Share, 2019, https://wid.world/world/\#sptinc_p99 p100_z/US;FR;DE; CN;ZA;GB;WO/last/eu/k/p/yearly/s/false/5.487/30/curve/false/ country (5.1.2020).

- Top $10 \%$ National Income Share, 2019, https://wid.world/ world/\#sptinc_p90p100_z/US;FR;DE;CN;ZA; GB;WO/last/eu/k/p/ yearly/s/false/25.253500000000003/80/curve/false/country (5.1.2020). 